NBER WORKING PAPER SERIES

\author{
DOES PROTECTING OLDER WORKERS FROM DISCRIMINATION MAKE IT \\ HARDER TO GET HIRED? EVIDENCE FROM DISABILITY DISCRIMINATION \\ LAWS \\ David Neumark \\ Joanne Song \\ Patrick Button \\ Working Paper 21379 \\ http://www.nber.org/papers/w21379 \\ NATIONAL BUREAU OF ECONOMIC RESEARCH \\ 1050 Massachusetts Avenue \\ Cambridge, MA 02138 \\ July 2015
}

This paper was prepared for the AARP conference on "Social Insurance and Lifecycle Events among Older Americans," December 2014. We are grateful to the Social Security Administration, through a grant to the Michigan Retirement Research Center (MRRC), for financial support. We are grateful to Doug Kruse, Richard Johnson, and anonymous reviewers for very helpful comments. All conclusions and opinions are solely ours. The views expressed herein are those of the authors and do not necessarily reflect the views of the National Bureau of Economic Research.

NBER working papers are circulated for discussion and comment purposes. They have not been peerreviewed or been subject to the review by the NBER Board of Directors that accompanies official NBER publications.

(C) 2015 by David Neumark, Joanne Song, and Patrick Button. All rights reserved. Short sections of text, not to exceed two paragraphs, may be quoted without explicit permission provided that full credit, including $\odot$ notice, is given to the source. 
Does Protecting Older Workers from Discrimination Make It Harder to Get Hired? Evidence from Disability Discrimination Laws

David Neumark, Joanne Song, and Patrick Button

NBER Working Paper No. 21379

July 2015, Revised September 2015

JEL No. J14,J71,J78

\section{ABSTRACT}

We explore the effects of disability discrimination laws on hiring of older workers. A concern with anti-discrimination laws is that they may reduce hiring by raising the cost of terminations and - in the specific case of disability discrimination laws - raising the cost of employment because of the need to accommodate disabled workers. Moreover, disability discrimination laws can affect non-disabled older workers because they are fairly likely to develop work-related disabilities, yet are not protected by these laws. Using state variation in disability discrimination protections, we find little or no evidence that stronger disability discrimination laws lower the hiring of non-disabled older workers. We similarly find no evidence of adverse effects of disability discrimination laws on hiring of disabled older workers.

David Neumark

Department of Economics University of California at Irvine

3151 Social Science Plaza

Irvine, CA 92697

and NBER

dneumark@uci.edu

Joanne Song

Department of Economics

SUNY Buffalo

441 Fronczak Hall

Buffalo, NY 14260

jsmclaug@buffalo.edu
Patrick Button

Department of Economics

Tulane University

6823 St. Charles Avenue

206 Tilton Hall

New Orleans, LA 70118

pbutton@tulane.edu 


\title{
Does Protecting Older Workers from Discrimination Make It Harder to Get Hired? Evidence from Disability Discrimination Laws
}

\begin{abstract}
We explore the effects of disability discrimination laws on hiring of older workers. A concern with antidiscrimination laws is that they may reduce hiring by raising the cost of terminations and - in the specific case of disability discrimination laws - raising the cost of employment because of the need to accommodate disabled workers. Moreover, disability discrimination laws can affect non-disabled older workers because they are fairly likely to develop work-related disabilities, yet are not protected by these laws. Using state variation in disability discrimination protections, we find little or no evidence that stronger disability discrimination laws lower the hiring of non-disabled older workers. We similarly find no evidence of adverse effects of disability discrimination laws on hiring of disabled older workers.
\end{abstract}

Keywords: older workers, hiring, disability, discrimination

\section{Introduction}

Discriminatory barriers to employment of older workers may constrain the effects of supply-side policy reforms intended to boost employment of older workers. Discrimination in hiring is particularly important, since substantially extending work lives is likely going require a good deal of employment in new part-time or shorter-term "partial retirement" or "bridge jobs," and not just extended employment of workers in their career jobs, in part as some older workers make transitions to jobs that are less physically taxing (Cahill et al., 2006; Johnson et al., 2009).

Although it is natural to ask how age discrimination laws affect barriers to employment of older workers, in this paper we study disability discrimination laws. There are two reasons why disability discrimination laws are germane to the question of barriers to employment of older workers generally. First, disabilities that can limit work and hence trigger protection by disability discrimination laws rise steeply with age, especially past age 50 or so (e.g., Rowe and Kahn, 1997); correspondingly, employer expectations that a worker will develop a disability in the near future should also rise steeply with age. Second, disability discrimination laws may do more to protect many older workers than do age discrimination laws. Many ailments associated with aging have become classified as disabilities (Sterns and Miklos, 1995), giving older workers an option of pursuing discrimination claims under either the Age Discrimination in Employment Act (ADEA) or the Americans with Disabilities Act (ADA). Moreover, 
ADA claims may be more likely to prevail because the ADA limits possible defenses more. ${ }^{1}$

Disability discrimination laws (like age discrimination laws) vary across states. We exploit state variation that makes state protections stronger than the federal ADA, studying how this variation is associated with hiring of older workers, although given the lack of variation in state disability discrimination laws over time, we are restricted to using cross-state variation in disability discrimination laws. We study disabled as well as non-disabled older workers; the latter may be affected adversely because of a higher likelihood of developing a physical impairment in the near future that may bring older disabled workers under the protection of disability laws. For the non-disabled, by assuming that disability discrimination laws only directly affect older, but not younger, non-disabled workers (because the likelihood of near-term disability for young workers is so low), we also conduct a difference-indifferences analysis estimating the effects of stronger state disability discrimination protections on hiring of older relative to younger non-disabled workers within a state. Although we cannot use a common difference-in-differences analysis based on variation in state laws over time, we believe our paper broaches an important question regarding disability discrimination laws and older workers, and provides some interesting first evidence.

\section{Related Research}

Anti-discrimination laws may boost employment mainly via reduced terminations, but could be ineffective at increasing hiring. In contrast to termination cases, in hiring cases it is difficult to identify a class of affected workers, and economic damages may be small - both of which reduce the attractiveness of hiring cases to plaintiffs and their attorneys. If anti-discrimination laws mainly raise the costs of terminating protected workers, they could unintentionally reduce hiring of protected groups (Bloch, 1994; Posner, 1995). The effects of age discrimination laws on hiring has been studied, and the evidence is mixed (Lahey, 2008; Neumark and Song, 2013; Neumark and Button, 2014).

\footnotetext{
${ }^{1}$ Unlike the ADEA, the ADA does not include an exception for bona fide occupational qualifications (BFOQs). BFOQ exceptions arise when age is strongly associated with other factors that pose legitimate business or safety concerns (e.g., Stock and Beegle, 2004; Posner, 1995; Starkman, 1992). Furthermore, age-related disabilities might be judged as amenable to "reasonable accommodation" by employers under disability discrimination laws, which usually require "reasonable accommodation" of the worker, making it much harder to justify an apparently discriminatory practice on the basis of business necessity (Gardner and Campanella, 1991).
} 
Moreover, the unintended consequence of reducing hiring of the protected group might be more severe for the effects of disability discrimination laws on older workers, for two reasons. First, if disability discrimination laws offer stronger protections than age discrimination laws, they may raise termination costs more. Second, employers should have a reasonable expectation of an older worker developing a disability requiring costly accommodation - reducing hiring of older non-disabled workers.

Existing research on the effects of disability discrimination laws studies employment rather than hiring, and reaches ambiguous conclusions. Acemoglu and Angrist (2001) and Deleire (2000) conclude that the ADA reduced employment among disabled individuals. Both studies identify the effects of the ADA from time-series changes in the employment of the disabled relative to the non-disabled, and hence cannot distinguish policy effects from other sources of different changes in the employment rates of these two groups (Houtenville and Burkhauser, 2004). Beegle and Stock (2003) also note that when the ADA was enacted all but two states had laws barring discrimination against the disabled, although there was heterogeneity in these laws, raising questions about what the time-series evidence identifies, although Acemoglu and Angrist (2001) report some cross-state evidence of larger employment declines of the disabled in states with more ADA-related discrimination charges.

Beegle and Stock (2003) use variation in state disability discrimination laws passed prior to the ADA, finding no clear employment effects, and no incremental effect of “reasonable accommodation” provisions in state laws. Kruse and Schur (2003) show that results from time-series evidence are sensitive to the definition of disability. Hotchkiss (2004) argues that the apparent decline in employment of the disabled reflects a decline in their labor force participation, mainly from (self) reclassification of nonparticipants as disabled, rather than a decline in demand. Jolls and Prescott (2005) try to identify separately the "reasonable accommodation" cost effects of the ADA, based on variation in state laws, suggesting that the reasonable accommodation provision reduced employment only in the short term.

Stock and Beegle (2004), like our study, extend the analysis to the non-disabled, arguing echoing the discussion in the Introduction - that older workers who are not disabled may receive greater protection from age discrimination when there are disability discrimination laws. Moreover, they test for 
interactions between age and disability discrimination laws. They find a positive interactive effect on employment of non-disabled workers aged 40-64, but a net effect of disability discrimination laws that is very small and statistically insignificant.

Our research differs in a number of ways. First, it include workers aged 65 and over - a group that is of considerable interest in terms of extending work lives, and for which disability rates are quite high. Second, it focuses on contemporaneous variation in state disability discrimination protections, including differences in these laws that were not considered earlier. Third, it emphasizes effects on nondisabled older workers. Fourth, it studies effects of disability discrimination laws on hiring, which we argue is important for extending work lives of older workers, and is the outcome most likely to be deterred by disability discrimination protections.

\section{Disability Discrimination Laws}

State disability discrimination laws are sometimes stronger than the federal ADA in three principal ways. Two of these increase the number of individuals who are protected under state law, via the definition of disability, or the minimum firm size to which disability discrimination laws apply. The third is higher potential compensation for plaintiffs, through higher or uncapped compensatory and punitive damages, relative to the capped damages available under the ADA. The first three columns of Table 1 display this variation in state disability discrimination laws. An appendix available from the authors documents the extensive legal research underlying Table 1, and provides more details on these laws than the brief description we provide here.

The minimum firm size for the ADA to apply is 15 . In our analysis, we distinguish states with a firm size minimum lower than 10 (substantially lower than the ADA minimum). When the firm size minimum is lower, more workers (and employers) are covered.

Defining disability is complex. Most states adopt the ADA definition, either explicitly or via case law. Some states use a laxer definition, changing a key part of the definition of disability from “substantially limits one or more major life activities” to either “materially limits” or just "limits.” Other states relax this criterion even more, simply requiring that the disability be "medically diagnosed" without 
regard to whether the impairment limits major life activities (Long, 2004). In our analysis, we distinguish states that use the broader medical definition of disability.

The ADA caps the sum of compensatory and punitive damages per claimant, with caps that are larger for larger firms. Some states allow larger potential damages. We distinguish states with larger damages than the $\mathrm{ADA}$; we base this classification on punitive rather than compensatory damages, since punitive damages are likely to drive large judgments. ${ }^{2,3}$

\section{Labor Market Data}

\section{Health and Retirement Study (HRS) Data}

Part of our analysis studies older workers only, using the RAND HRS, a version of the regular HRS data that makes it easier to track individuals across waves of the survey. We use data from nine waves from 1992 through 2008, avoiding the period of the Great Recession. The oldest cohort in the HRS sampling frame was born in 1924 and the youngest cohort in 1955; spouses of the respondents can have a wider age range. We restrict our data (for almost all of our analyses) to respondents aged 53 to 69, and avoid spouses outside these age ranges. ${ }^{4}$ We study men only, to avoid complications from the very different labor force participation patterns of men and women in the covered cohorts.

To measure our dependent variable - hiring - as accurately as possible, we use more information not only on employment status and the job at each HRS interview, but also questions on labor market transitions between the interviews, or “inter-wave” information. Employment transitions from selfemployed or not working to employed are coded as hires, as are transitions from employed at wave t-1 to working for a different employer at wave t (HRS waves are two years apart). Respondents who make transitions from non-employment at wave $\mathrm{t}-1$ to self-employed or non-employment at wave $\mathrm{t}$ are coded as

\footnotetext{
${ }^{2}$ Table 1 also lists information on state age discrimination laws (from Neumark and Song, 2013), which we use in some analyses. Details are provided in the same appendix referenced above.

${ }^{3}$ There is not enough variation in state laws to estimate separate effects of having two particular laws (or all three). Table 1 shows that the set of states with the broader definition is quite small, and only one state (New Jersey) overlaps this dimension of state laws with larger damages. The same is true for larger damages and smaller firm size (West Virginia). There is no overlap between broader definition and smaller firm size.

${ }^{4}$ HRS respondents go down to age 51 in the first wave, but we can only observe hiring outcomes starting with the second wave, which is two years later.
} 
hires if they report working for a wage or salary between waves, and otherwise are coded as non-hires. ${ }^{5}$

We focus on those initially non-employed (in period t-1), asking if they were hired as of period t. Job-to-job transitions are harder to interpret. They capture new hiring as well as outcomes from adverse outcomes at the previous job, whereas we can assume that non-employed workers who become employed were looking to get hired. Thus, the estimated effects of disability discrimination laws on hiring of the previously non-employed better isolate the effects of these laws on hiring. Nonetheless, we have examined all of our analyses using all hiring instead, and the qualitative conclusions are unchanged; these results are in an appendix available from the authors upon request.

We do not exclude those who report that they are retired, or out of the labor force, from those at risk of being hired, because there are frequent transitions back to employment for workers classified this way. In the RAND HRS, the hiring rate out of retirement is 0.09 , vs. 0.125 overall. To be sure, the hiring rate is much higher for, say, the unemployed (0.642). But there are far more retired than unemployed workers, so that for our sample, hires out of retirement constitute 54.7 percent of hires, versus 25.1 percent for hires out of unemployment. Similarly, the hiring rate for those who report "out of the labor force” is 0.358 .

Survey of Income and Program Participation (SIPP) Data

To look at a larger age range needed for our difference-in-differences analysis, we use SIPP data. To correspond to the years covered by the HRS, we use data from the 1992, 1993, 1996, 2001, and 2004 SIPP panels. The last panel extends into 2007, and we use the age range 15-69. Like with the HRS, we do not use the most recent SIPP data (the 2008 panel), to avoid the Great Recession, and we restrict our analysis to men.

We exploit the longitudinal nature of the data to construct person-month hiring data. Our hiring measure is mainly based on respondents' employment status, and information on whether a worker

\footnotetext{
${ }^{5}$ In some cases, we have to make a determination even when the information is not decisive. Specifically, the questions on work between waves were not asked for respondents who went from self-employed to not employed or self-employed, if they do not know when they stopped the initial self-employed job; we assumed these individuals were not hired between waves. Also, many observations are missing inter-wave information and classified as "inapplicable or partial interview" in the codebook. For cases with missing data and transitions from wave $\mathrm{t}-1$ to $\mathrm{t}$ between disabled, retired, and not in the labor force, we assumed no hire occurred.
} 
reported changing employer and when they began working for the new employer. Although respondents report their employment status at both a weekly and monthly frequency, the information on when they began working for the new employer is only available at the monthly level. If respondents report having a job for at least one week during the reference month, we record them as employed. If they report having a job for at least one week during the reference month and owning their own business, we define them to be self-employed. If they report having no job, we define them to be not working. If they make a transition from self-employed or not working to employed, we code them as hired. If they are employed at $\mathrm{t}-1$ and employed at $\mathrm{t}$ and report that they started their job at $\mathrm{t}$, then we code them as hired at $\mathrm{t}$. As in the HRS analysis, we focus on the sample not employed at period t-1, and estimate models for whether these respondents were hired as of period t. ${ }^{6}$

The SIPP interviews respondents every four months and reports about their previous four months. A well-known limitation of the SIPP is a strong tendency for individuals to report the same value within a four-month interview period (“seam bias”) (Ham et al., 2009). We address this seam bias by including an indicator for being on a seam between two interview waves. Other control variables are described in the notes to the tables and figures discussed below.

Like with the HRS, self-reported retirement does not preclude hiring. The hiring rate is 0.049 for those who say they have never retired, 0.013 for those who say they have ever retired, and 0.034 for those who report that they are out of the labor force. (Hiring rates are much lower in the SIPP because of the higher frequency of the data.)

\section{Disability}

We focus on self-reported work-impairing disabilities. The HRS question is "Do you have any impairment or health problem that limits the kind or amount of paid work you can do?” The SIPP question is very similar: “[Do you] have a physical, mental, or other health condition that limits the kind

\footnotetext{
${ }^{6}$ There is other information that could in principle be used to identify hiring, in particular the unique job identification number across waves. However, we do not use this information due to reported inconsistency in implementation (Stinson, 2003).
} 
or amount of work [you] can do?”7 These questions are asked in each wave. We use reported disability as of time $\mathrm{t}$ and whether one was hired at time $\mathrm{t}$ (out of non-employment in $\mathrm{t}-1){ }^{8}$

We also explore an alternative definition based on self-reported fair or bad health (the additional options are good, very good, or excellent). This definition has the advantage of not being tied to whether one is working, although it does not refer specifically to whether a disability or medical condition limits work. Self-reported health data in the SIPP are only collected in topical modules in selected waves of each panel, and hence may less accurately reflect disability status at the time when hiring is measured. ${ }^{9}$

The two disability measures overlap but are not identical. In the HRS, 59 percent of those who report a work-limiting disability report fair or bad health, and 64 percent of those who report fair or bad health also report a work-limiting disability. However, the two measures have similar relationships with difficulties in activities and instrumental activities, functional limitations, and doctor-diagnosed medical problems (table available upon request).

\section{Empirical Analysis}

\section{Methods}

We study the effects of disability discrimination laws on hiring in a number of ways. We have to rely on cross-state variation in the strength of state disability discrimination laws, because there are no changes in these laws during the periods we study, for states uniquely identified in the SIPP. For both data sets, we present a rich analysis of differences in hiring rates by single-year age cells, for both the non-disabled and the disabled, in states with stronger and weaker disability discrimination laws along each of the dimensions discussed earlier.

We also estimate difference-in-differences models for the non-disabled only, using the SIPP to leverage differences between younger and older workers. In particular, perhaps our central focus is the effects of disability discrimination laws on the hiring of non-disabled older workers, who could be

\footnotetext{
${ }^{7}$ This disability variable in the SIPP is asked only for individuals who are 69 years or younger, which determines our upper age limit.

${ }^{8}$ In results available upon request, we show that the age profile of disability is quite similar using a more persistent definition based on repeated answers that one has a work-limiting disability, and that our key results are robust to using this more persistent definition.

${ }^{9}$ Since SIPP interviews respondents with high frequency, we backfill the self-reported health status with the first available information, then update disability status as respondents are asked subsequently.
} 
adversely affected because of a high probability of developing a disability and becoming protected by these laws.

Our difference-in-differences strategy is based on a rather sharp rise in disability rates (see Figure 1, discussed below) at around age 50, and the plausibility of the assumption that employers are little concerned with younger non-disabled workers becoming disabled and protected by disability discrimination laws. In this strategy, differences in hiring rates for those who are non-disabled and under age 50 (or similar thresholds) capture state differences arising from factors that might be coincidentally correlated with state disability discrimination laws, and hence control for these factors in a similar way to how older workers prior to the advent of these laws would serve as controls in a difference-in-differences estimator using only older workers, if there were variation in these state laws over time. Thus, the differences associated with these laws for those who are non-disabled and over age 50 relative to those who are non-disabled and under are 50 are more likely to reflect the causal effects of these laws.

In using this strategy, we are trading off a stronger assumption in the hopes of getting more convincing causal evidence. Of course we cannot decisively rule out effects of disability discrimination laws on younger non-disabled workers. Finally, reflecting this, it would not make any sense to implement this strategy for the disabled because hiring of the disabled of all ages could be affected by disability discrimination laws.

\section{Descriptive Statistics}

Figure 1 shows self-reported work-impairing disability rates by age. In the HRS data, these rates rise largely monotonically with age, from around 15 percent near age 55 to 25 percent at age 65-70. ${ }^{10}$ The larger age range in the SIPP data reveals more non-linearity in this relationship. The disability rates in the age range covered by the HRS are quite similar, but the figure reveals quite low and stable disability rates through about age 40, in the 5-8 percent range, a slight steepening during the 40s, and then fairly sharp increases beginning in the 50 s. $^{11}$

Table 2 reports descriptive statistics for the variables used in our analysis. For the SIPP, we

\footnotetext{
${ }^{10}$ In the following analyses we restrict the HRS sample to be no older than 69, to line up with the oldest age for which this disability question is asked in the SIPP.

11 The slight dip after age 60 may be related to the relationship between whether one works and how one answers this question, although it is not clear why this differs in the two datasets.
} 
report these for both the full sample and those aged 53-69, which provides a better comparison for the ages common to the SIPP and the HRS for which we also have the disability question. The measured hiring rate is much higher in the HRS, because of the biennial frequency in the HRS versus the monthly frequency in the SIPP. The descriptive statistics for the control variables are comparable in the two datasets, for the same age ranges.

Hiring Rates by Age and Disability Discrimination Laws

Figures 2 and 3 present information on hiring rates by age. Each figure has three panels, with two graphs in each - one for the non-disabled, and one for the disabled. Each panel displays predicted hiring rates, for single-year age cells, for states with a stronger disability discrimination law provision and states without that stronger provision, in turn for broader definition of disability, larger damages, and a lower minimum firm-size cutoff.

The predictions come from a probit model for hiring including the controls listed in the notes to the figures, a set of dummies for every age group, and a full set of interactions between these age dummy variables and a dummy variable for the stronger disability discrimination protection under consideration. ${ }^{12}$ Using the probit estimates, we compute the predicted hiring probability at each age, for each set of states (with and without the stronger provision), setting the other controls at their sample means. Thus, these figures show the difference in hiring rates by age for otherwise identical workers, based on whether that worker resides in a state with the stronger disability discrimination protection or not.

In Figure 2, based on HRS data, Panel A focuses on the distinction between states with or without the broader definition of disability than the ADA. For the non-disabled (left-hand graph), it appears that hiring rates are generally lower in states with the broader definition, consistent with the conjecture that stronger disability discrimination laws can deter hiring of older non-disabled workers. For the disabled (right-hand graph), the evidence looks similar albeit more pronounced, suggesting that stronger protections can lower hiring of older disabled workers.

Panels B and C present similar analyses for larger damages and a lower firm-size cutoff,

\footnotetext{
12 Note that we do not control for the unemployment rate or another aggregate labor market indicator, which would be endogenous with respect to hiring (especially of the large non-disabled workforce).
} 
respectively. These figures show much less evidence of a systematic relationship between stronger state laws and hiring of older workers. In states with larger damages, the hiring rate of the non-disabled is generally lower for those in their 60s, but the difference is small. For the disabled there is no clear difference. ${ }^{13}$ For the lower firm-size cutoff, there is no clear evidence of a difference in hiring rates for either the non-disabled or the disabled.

Table 3 summarizes the information from these figures, in the columns labeled "HRS.” Based on the estimates by single-year ages, we form different age ranges, for each of which we compute the average difference in hiring rates between states with and without the stronger provision, the percentage of the estimates that are positive, and the p-value for the joint test that the estimated (single-year) differences in that age range are equal to zero.

For example, the evidence from Panel A of Figure 2, indicating that hiring rates for the nondisabled were lower in states using the broader definition of disability, is reflected most strongly in the fifth row of column (1), for the 62-69 age range. On average the difference in the estimated hiring rates was -0.130 ; the sign is negative because hiring rates at these ages are lower for states using the broader definition. The majority of the estimates are negative, as the figure also shows. However, the hiring rate differences over this age range are not statistically significant; the p-value from the joint test that the differences in this age range are all zero is 0.694 .

The remaining information in columns (1) and (2) reports similar information for the disabled as well, and for some age ranges that align better aligned with the SIPP data. While the point estimates are consistent with the broader definition of disability lowering hiring rates for older disabled and nondisabled workers, for age ranges that encompass the 60 s, the differences are not statistically significant. ${ }^{14}$ Columns (5)-(6) and (9)-(10) provide similar information for the other two dimensions of strong state disability protections (from Panels B and C of Figure 2). The weaker indications of differences in

\footnotetext{
${ }^{13}$ We experimented with distinguishing between states with larger damages than the ADA but damages that are still capped, and states with uncapped damages (Table 1). There were no distinct differences between these two groups of states, perhaps in part because there are only four uncapped states and two of them (Alaska and Maine) have very small populations. Thus, all results reported in the paper group together the states with larger damages than the ADA.

${ }^{14}$ Moreover, these joint tests for the age ranges reported in Table 3 do not mask any consistent evidence of significant effects for other age ranges (such as smaller ranges within those reported in the table). There is only a smattering of significant coefficient estimates on the age $\times$ law interactions at isolated single-year ages.
} 
hiring rates at older ages associated with larger damages and a lower firm-size cutoff are reflected in these columns. None of the estimated differentials for the age ranges considered in this table is jointly significant, although for larger damages the estimated differentials for all three of the older age ranges for non-disabled workers are negative (column (5)), and for smaller firm size the estimated differentials for all three of the older age ranges for disabled workers are negative (column (10)).

Figure 3 presents results for the SIPP data, covering a broader age range. In Panel A, which focuses on the broader definition of disability than the ADA, the evidence for the same age ranges covered by the HRS is different, with no clear indication that hiring rates for non-disabled older workers are lower in states with the broader definition, and no apparent difference at any ages for the disabled. This is reflected, for example, in the fifth row (ages 62-69) of columns (3) and (4) of Table 3, where the average differences in hiring rates are much smaller than those for the same age ranges in columns (1) and (2), and effectively zero. Nonetheless, in the last two rows of the table, for the non-disabled 53-61 and 53-69 age ranges, for both the broader definition of disability and larger damages, the estimates are negative and statistically significant. The estimated differences are very small - in the -0.001 to -0.003 range - but the SIPP hiring rate for the non-disabled 53-69 year-olds is only 0.018 , so a difference of -0.002 represents about a 10 -percent lower hiring rate. However, the percentages of positive estimates are often quite close to 50, suggesting this evidence is not strongly indicative of an effect in one direction.

Curiously, Panel A of Figure 3 suggests that the hiring rate for the non-disabled tends is be lower in states using the broader definition of disability - up to the late $40 \mathrm{~s}$ - as do the estimates in the top rows of columns (3) and (4) of Table 3, where for the non-disabled the average estimated differences in hiring rates between states that use the broader definition and states that do not are negative for ages 20-29, 3039, and 40-49 - in all cases statistically significant. ${ }^{15}$ The estimated differences are larger than for the older ranges, but these are relative to a much higher hiring rate (about 0.12, as shown in Figure 3), and hence are more similar in relative terms. For the disabled, there are no clear differences in hiring rates in the SIPP at young ages based on the definition of disability. Finally, the differences in hiring rates for older disabled workers are very small and not in a consistent direction.

\footnotetext{
${ }^{15}$ Standard errors in the SIPP data are much lower because of far larger samples.
} 
Figure 3, Panel B examines larger damages in the SIPP data. There is less evidence of lower hiring for the younger non-disabled in states with stronger laws; see also column (7) of Table 3, compared to column (3). There is evidence of more hiring of the disabled at many ages, most pronounced at younger ages. As Table 3 shows, though, the estimated differences at younger ages are small except for ages 20-29, and generally not statistically significant. Finally, Figure 3, Panel C reports the results for the lower firm-size minimum, which is not associated with differential hiring.

Thus, there is some evidence from the HRS that using a broader definition of disability reduces hiring of both non-disabled and disabled older workers, and larger damages reduce hiring of older, nondisabled workers. However, this evidence is not statistically significant. The point estimates for the disabled are consistent with a broader definition of disability deterring hiring of older disabled workers, which could stem from higher costs of employing or terminating a disabled worker. The point estimates for the non-disabled are consistent with stronger protections deterring hiring of non-disabled older workers, perhaps because employers regard it as relatively likely that these workers will become disabled and fall under these stronger protections.

The results from the SIPP are partly consistent, with some evidence - albeit weak - of lower hiring rates for non-disabled older workers in states with a broader disability definition and larger damages. However, the estimates indicate lower hiring rates for non-disabled younger workers in states with stronger protections, especially the broader disability definition, which is hard to understand because employers seem unlikely to be concerned that non-disabled younger workers will become disabled. Of course this evidence for non-disabled younger workers may not be causal, instead just reflecting correlations of stronger disability discrimination protections with other state-level factors influencing employment. This perspective underlies our difference-in-differences strategy - discussed below estimating the effects of stronger disability discrimination protection on non-disabled workers from the relative effects of these protections on older versus younger non-disabled workers, using the younger workers to control for other influences on hiring that are correlated with disability discrimination laws.

To see whether the results are sensitive to the definition of disability, in Table 4 we repeat the analysis defining disability based on self-reported fair or bad health. The results are in many respects 
similar. ${ }^{16}$ Turning to the key HRS results, for older non-disabled workers, hiring is lower in states with a broader definition of disability or larger damages. In columns (1) and (5) all but one of the estimates are negative, and all the shares positive are low, although again none of the estimates is statistically significant. The SIPP evidence summarized in columns (3) and (7) is less clear. The estimates are similar to those in Table 3, but often smaller in absolute value, and less consistently negative. For younger workers in the SIPP data, there is less evidence that stronger state disability discrimination laws reduce employment of non-disabled younger workers (e.g., the smaller estimates for 20-29, 30-39, and 40-49 year-olds in column (7), and the fact that all of the estimates for the non-disabled in these age groups are less negative in Table 4 than in Table 3). Overall, though, there are not systematic differences using the alternative disability measure.

\section{Difference-in-Differences Estimates}

Finally, we turn to the difference-in-differences results. These are based on linear probability models of hiring of the form:

$$
\mathrm{H}_{\text {ist }}=\alpha+\mathrm{LAW}_{\mathrm{s}} \cdot \mathrm{OLD}_{\mathrm{ist}} \beta+\mathrm{X}_{\mathrm{ist}} \delta+\sum_{\mathrm{a}} \mathrm{A}_{\mathrm{a}} \omega_{\mathrm{a}}+\sum_{\mathrm{s}} \mathrm{S}_{\mathrm{s}} \theta_{\mathrm{s}}+\sum_{\mathrm{t}} \mathrm{T}_{\mathrm{t}} \rho_{\mathrm{t}}+\varepsilon_{\text {ist. }}
$$

The models include the individual-level (X) and other controls (A, for single-year age dummy variables) as before, with two changes relative to the earlier specifications. First, the models include fixed state effects (S) in addition to the fixed year effects (T). ${ }^{17}$ Second, rather than including interactions between all of the single-year age dummy variables and the indicator for a stronger state disability discrimination protection (LAW), a simple interaction between the latter indicator and a dummy variable for older workers (OLD) is included - using alternatively thresholds of 50, 55, and 60. The state fixed effects subsume main effects of the disability discrimination law dummy variables, capturing differences among states in hiring rates of younger workers. ${ }^{18}$ The LAW $\times$ OLD interactions capture the differential

\footnotetext{
${ }^{16}$ The corresponding figures are available upon request.

${ }^{17}$ As we noted earlier, there is no variation in state disability discrimination laws in our sample period for states in the SIPP that are uniquely identified, which is why we cannot include fixed state effects in the regressions underlying Tables 3 and 4 and Figures 2 and 3. For the difference-in-differences analysis, however, we focus on the non-disabled only, and make the assumption that the differential effects of these laws on older workers represents the effect of disability discrimination protections on older non-disabled workers. Under this assumption there are differences, within state, in the effects of these laws on older and younger workers, which is why the fixed state effects are separately identified.

18 There are two changes in state disability laws from 1992 through 2008. One change in Washington for definition
} 
effects of state disability discrimination laws on older versus younger workers. Assuming that variation across states in hiring rates for younger workers does not reflect the effects of these laws, the LAW $\times$ OLD interactions capture the effects of state disability protections on older workers.

We use the SIPP data for this analysis because we need the younger workers as controls. The results are reported in Table 5. In columns (1)-(3) we introduce each of our stronger features of state disability discrimination laws separately, and in column (4) they are all included. The estimates paint a rather clear picture. Regardless of the age threshold used, the broader definition of disability, and in some cases larger damages, appear to raise rather than to lower hiring of non-disabled older workers. For the broader definition of disability this is true for each age threshold in column (1), as well as in column (4), where the effects of the broader definition, larger damages, and a lower firm-size cutoff are estimated simultaneously. The estimates are sizable - elevating the hiring rate by approximately 0.014 - and statistically significant in all six cases (four at the five-percent significance level). There is similar evidence for larger damages in two cases (column (2), for the age 50 and age 55 thresholds), but no such evidence for a lower firm-size cutoff.

The evidence that stronger disability discrimination protections increase hiring of non-disabled older workers is inconsistent with the conjecture that such laws deter hiring of older, non-disabled workers, and points in the opposite direction. A positive effect of stronger disability protections on the hiring of older non-disabled workers might seem counterintuitive. One possibility is that workers who do not self-report work-limiting disabilities exhibit other characteristics that employers perceive as making older workers likely to later qualify for protections under disability discrimination laws. To assess this possibility, columns (1)-(4) of Table 6 report results defining disability based on self-reported fair or bad health, which might be more of a signal to employers of the likelihood of future disabilities. The estimates no longer point to significant positive effects of a broader definition of disability on the hiring or non-disabled older workers; the estimates are still positive, but smaller than in Table 5, and almost none of them are statistically significant. Thus, with this alternative definition of disability, the

of disability and another change in Vermont for larger damages. However, our sample period does include the change in Washington noted in Table 1, and Vermont is not uniquely identified for earlier SIPP panels during the period when there was a law change in larger damages. Hence, main effects from both specifications are subsumed by state fixed effects. 
counterintuitive finding of stronger disability discrimination protections helping non-disabled older workers is no longer present.

The most significant and broader point, however, is that we find no evidence of adverse effects of disability discrimination laws on older workers. Although some of earlier results using only cross-state variation (in Tables 3 and 4) suggested that stronger disability discrimination protections reduce hiring or older non-disabled workers, the difference-in-differences analysis gives no such indication.

Finally, columns (5)-(8) of Tables 5 and 6 add interactions between our older worker thresholds and the two indicators of stronger age discrimination laws that were significant influences on employment of older workers in Neumark and Song (2013) - larger damages and a firm-size minimum of fewer than 10 employees. The estimated effects of disability discrimination laws are robust to controlling separately for state age discrimination protections. We also re-estimated these models dropping 40-49 year-olds, to get a cleaner distinction between older ages at which disability is rising and younger ages when it is not (see Figure 1). The results were qualitatively very similar (available upon request).

\section{Conclusions}

We explore the effects of disability discrimination laws on hiring of older workers. These laws are supposed to help disabled workers, but may have unintended adverse effects on hiring, by raising the cost of terminations and cost of employment stemming from accommodating disabled workers. This unintended adverse effect could also arise for younger disabled workers of any age, and could be stronger because of longer projected tenure with an employer. The new hypothesis we also explore in this paper is that disability discrimination laws can deter hiring of older non-disabled workers, for whom the probability of developing a work-related disability is sizable. We use state variation in disability discrimination protections, which can strengthen the coverage relative to the ADA by using a broader definition of disability, allowing larger damages, or applying to smaller firms.

Our best evidence comes from difference-in-differences specifications that compare hiring of non-disabled older and younger workers in states with stronger and weaker disability discrimination protections. This evidence suggests that stronger state disability discrimination laws do not lower the hiring of non-disabled older workers, using either of two definitions of disability. Although disability 
discrimination laws may imply future costs of hiring older non-disabled workers, age discrimination protections may deter employers from acting on this behavior; alternatively, hiring of older workers may be sufficiently short-term that these future costs have little influence on employer behavior, or employers may simply be myopic. When we use a work-limiting measure of disability, we also find evidence that a broader definition of disability or larger damages may boost hiring of older workers. All of this evidence is inconsistent with the conjecture that stronger disability protections deter hiring of older, non-disabled workers. Although simpler evidence from cross-state variation in laws and hiring rates of older workers suggests that stronger state disability protections may reduce hiring of older, non-disabled workers, this is not statistically or substantively strong, and is less plausibly causal. Finally, there is no indication that stronger disability discrimination laws deter hiring of disabled workers. Overall, then, we find little or no evidence of adverse effects of disability discrimination laws on older workers, and some of our more compelling evidence points to positive effects.

These results may also have more general implications for thinking about anti-discrimination laws. If there are adverse effects of discrimination protections on hiring, they may be most likely to arise for disability discrimination laws, because the accommodation requirements of disability laws can imply higher costs, and there are weaker defenses available to employers. In that sense, this paper may provide a particularly informative test of whether discrimination laws have the unintended consequence of reducing hiring of protected groups. Moreover, these unintended consequences could in principle arise for non-disabled older workers for whom employers could face future costs from disability, but who are not yet protected by disability discrimination laws. The fact that we do not find such evidence might, therefore, mitigate concerns about adverse unintended consequences of anti-discrimination laws for the groups they protect.

It could also be the case, however, that this conclusion does not extend beyond protections that are important for older workers (both age discrimination laws and disability discrimination laws). Given low expected tenure with the employer, termination costs for older workers may not loom large in employers' calculations. Consistent with this idea, Neumark and Button (2014) found that it was only in the period after the Great Recession that stronger age discrimination laws appeared to reduce hiring of older workers. In a period of extreme uncertainty about product and hence labor demand, employers may 
have been more concerned that they would want to terminate an older worker well before that worker wanted to leave the firm. 


\section{References}

Acemoglu, Daron, and Joshua D. Angrist. 2001. "Consequences of Employment Protection? The Case of the Americans with Disabilities Act.” Journal of Political Economy, Vol. 109, pp. 915-57.

Beegle, Kathleen, and Wendy A. Stock. 2003. "The Labor Market Effects of Disability Discrimination Laws.” Journal of Human Resources, Vol. 38, pp. 806-59.

Bloch, Farrell. 1994. Antidiscrimination Law and Minority Employment. Chicago: University of Chicago Press.

Cahill, Kevin E., Michael D. Giandrea, and Joseph F. Quinn. 2006. "Retirement Patterns from Career Employment.” The Gerontologist, Vol. 46, pp. 514-23.

Deleire, Thomas. 2000. "The Wage and Employment Effects of the Americans with Disabilities Act.” Journal of Human Resources, Vol. 35, pp. 693-715.

Gardner, Russell H., and Carolyn J. Campanella. 1991. "The Undue Hardship Defense to the Reasonable Accommodation Requirement of the Americans with Disabilities Act of 1990.” Labor Lawyer, Vol. 7, pp. 37-51.

Ham, John C., Xianghong Li, and Lara Shore-Sheppard. 2009. "Seam Bias, Multiple-State, MultipleSpell Duration Models and the Employment Dynamics of Disadvantaged Women.” NBER Working Paper No. 15151.

Hotchkiss, Julie L. 2004. "A Closer Look at the Employment Impact of the Americans with Disabilities Act.” Journal of Human Resources, Vol. 39, pp. 887-911.

Andrew J., and Richard V. Burkhauser. 2004. "Did the Employment of People with Disabilities Decline in the 1990s, and was the ADA Responsible: A Replication and Robustness Check of Acemoglu and Angrist (2001).” Research and Rehabilitation Training Center for Economic Research on Employment Policy for Person with Disabilities, August 2004.

Johnson, Richard W., Janette Kawachi, and Eric K. Lewis. 2009. "Older Workers on the Move:

Recareering in Later Life.” Washington, DC: AARP Public Policy Institute.

Jolls, Christine, and J. J. Prescott. 2005. "Disaggregating Employment Protection: The Case of Disability Discrimination.” Harvard Public Law Working Paper No. 106.

Kruse, Douglas, and Lisa Schur. 2003. "Employment of People with Disabilities Following the ADA.” Industrial Relations, Vol. 42, pp. 31-66.

Lahey, Joanna. 2008. "State Age Protection Laws and the Age Discrimination in Employment Act." Journal of Law and Economics, Vol. 51, pp. 433-60.

Long, Alex. 2004. "State Anti-Discrimination Law as a Model for Amending the Americans with Disabilities Act.” University of Pittsburgh Law Review, Vol. 65, pp. 597-653.

Neumark, David, and Patrick Button. 2014. "Did Age Discrimination Protections Helps Older Workers Weather the Great Recession?” Journal of Policy Analysis and Management, Vol. 33, pp. 566-601.

Neumark, David, and Joanne Song. 2013. "Do Stronger Age Discrimination Laws Make Social Security Reforms More Effective?” Journal of Public Economics, Vol. 108, pp. 1-16.

Posner, Richard A. 1995. Aging and Old Age. Chicago: University of Chicago Press.

Rowe, John W., and Robert L. Kahn. 1997. “Successful Aging.” The Gerontologist, Vol. 37, pp. 433-40.

Sperino, Sandra F. 2010. “The New Calculus of Punitive Damages for Employment Discrimination Cases.” Oklahoma Law Review, Vol. 62, pp. 701-34.

Starkman, Paul E. 1992. “Alleging a 'Pattern or Practice” under ADEA: An Analysis of the Impact and 
Problems of Proof.” Labor Lawyer, Vol. 8, pp. 91-123.

Sterns, Harvey L., and Suzanne M. Miklos. 1995. “The Aging Worker in a Changing Environment: Organization and Individual Issues.” Journal of Vocational Behavior, Vol. 47, pp. 248-68.

Stock, Wendy A., and Kathleen Beegle. 2004. "Employment Protections for Older Workers: Do Disability Discrimination Laws Matter?” Contemporary Economic Policy, Vol. 22, pp. 111-26. 
Figure 1: Disability by Age in HRS and SIPP Data

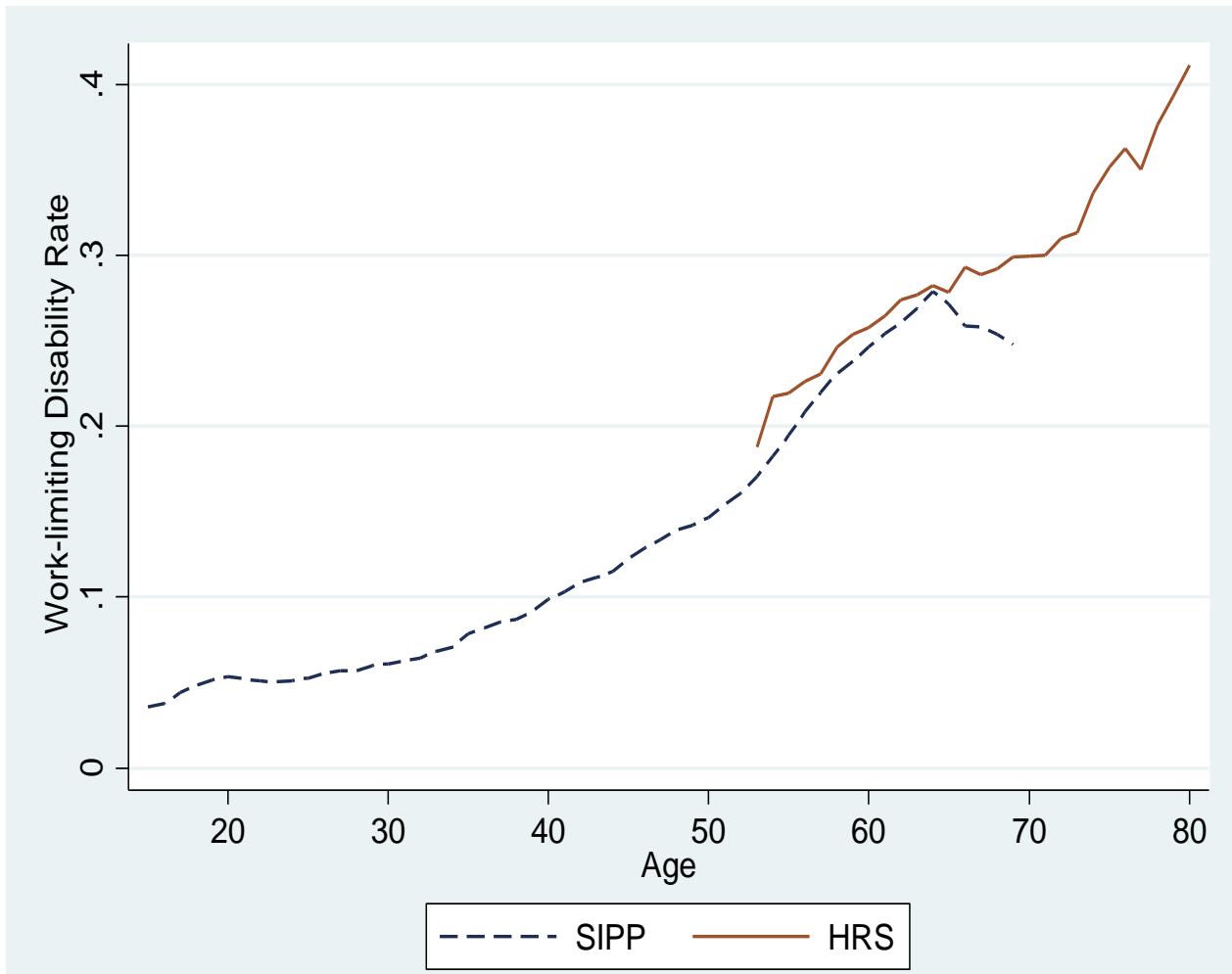

Notes: The disability rates are based on raw data, without adjustment. In the HRS, the disability definition is based on the question "Do you have any impairment or health problem that limits the kind or amount of paid work you can do?” In the SIPP, the disability definition is based on the question "[Do you] have a physical, mental, or other health condition that limits the kind or amount of work [you] can do? In the SIPP, this question is asked only for respondents aged 69 or younger. 


\section{A. By Definition of Disability under Disability Discrimination Laws}

Non-disabled

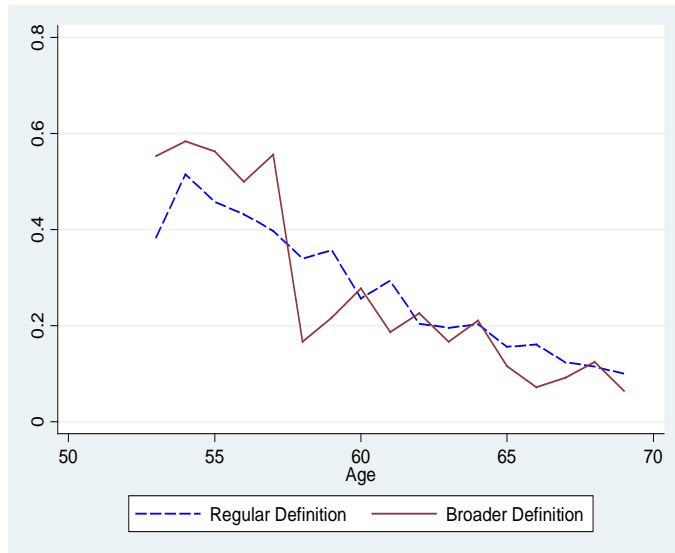

Disabled

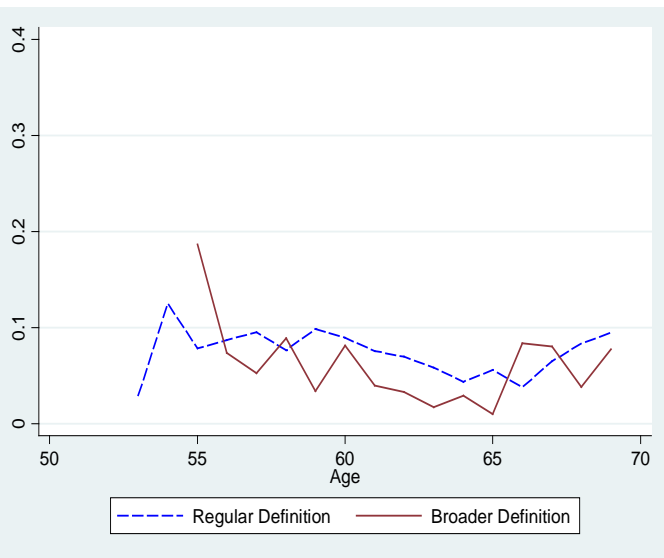

B. By Damages under Disability Discrimination Laws

Non-disabled

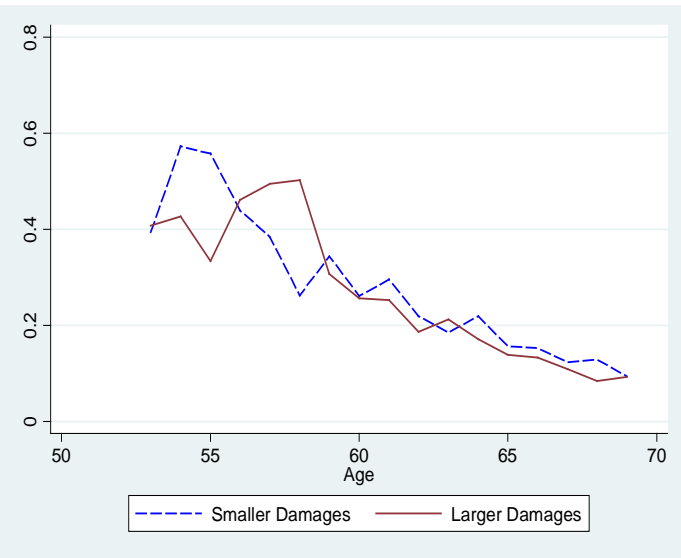

Disabled

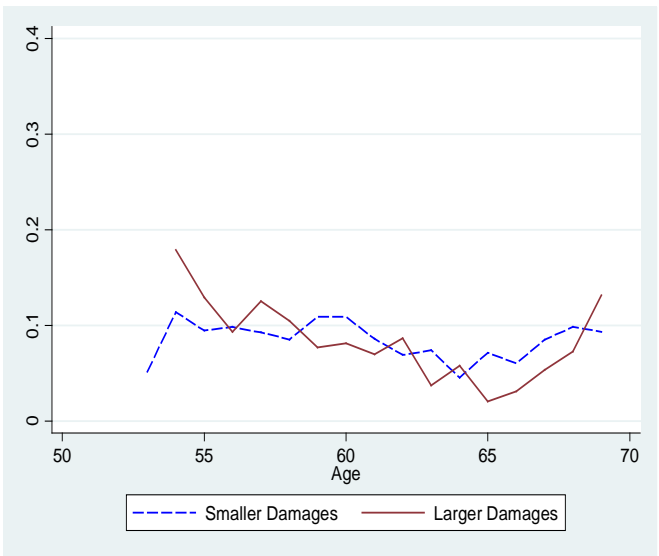

C. By Firm-Size Minimum under Disability Discrimination Laws Non-disabled

Disabled
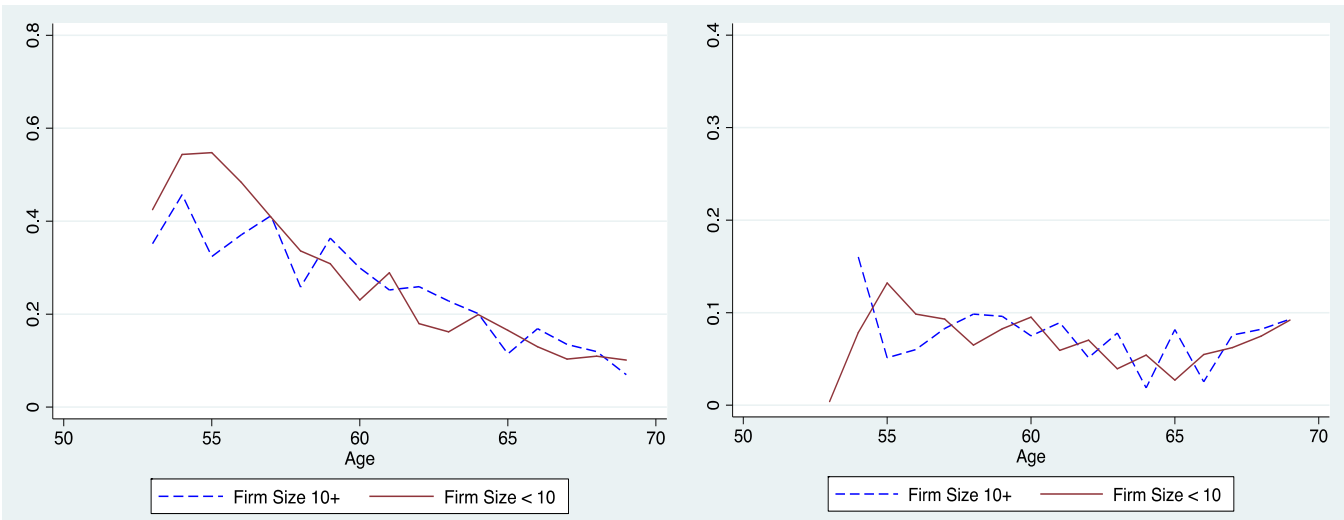

Notes: We use 1992-2008 HRS data for this analysis. HRS restricted data with state identifiers are used. The sample period for this analysis is 1992 through 2008. We restrict the sample to males who are 53 to 69 and use person-level HRS sampling weights. We use probit models to calculate the predicted hiring probability for each age in years conditional on respondents being not working at $\mathrm{t}-1$. The models are estimated separately for the non-disabled and the disabled. Each specification includes year fixed effects, single-year age dummy variables, and interactions between these age dummy variables and a dummy variable for the stronger disability discrimination protection indicated in the graph. The individual-level controls include urban-rural status, race, marital status, education level. Urban-rural status includes urban, suburban, or exurban residence; race includes white, black, and other; marital status includes married and married with spouse absent, partnered, separated/divorced/widowed, and never married; education includes less than high school, GED or high school graduate, some college, and college and above. The predicted probability of hiring at each age is evaluated at the sample means of the controls. See the text and Table 1 for discussion and classification of states by characteristics of disability discrimination laws. See the notes to Figure 1 for the definition of disability in the HRS. 
Figure 3: SIPP Hiring Rates (from Non-Employment), for Non-Disabled and Disabled

\section{A. By Definition of Disability under Disability Discrimination Laws \\ Non-disabled \\ Disabled}

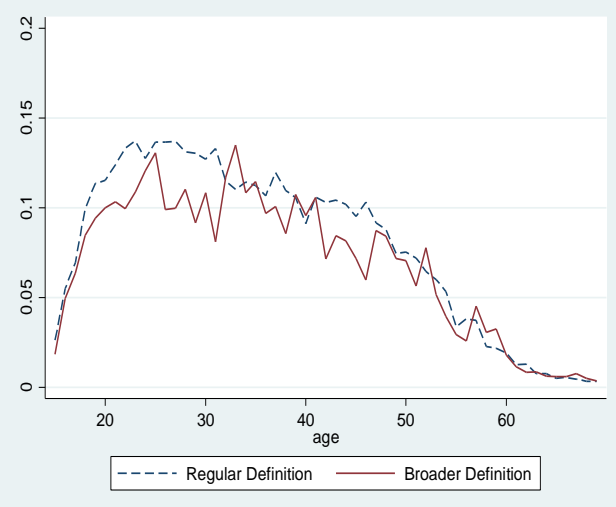

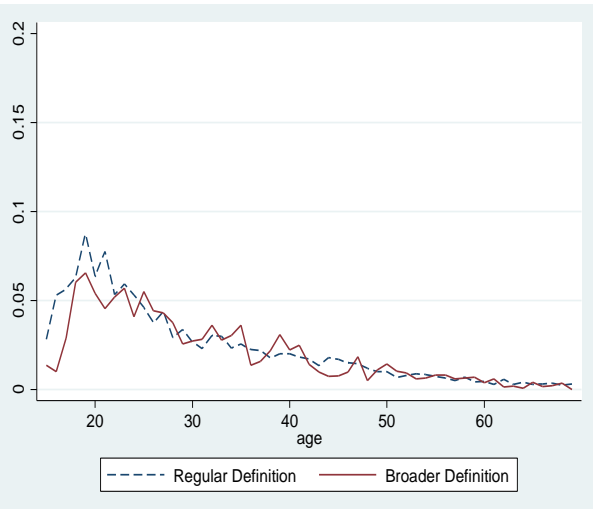

B. By Damages under Disability Discrimination Laws

Non-disabled

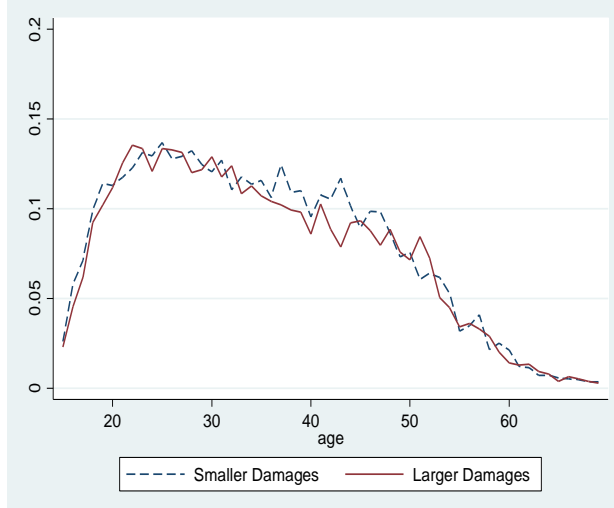

C. By Firm-Size Minimum under Disability Discrimination Laws

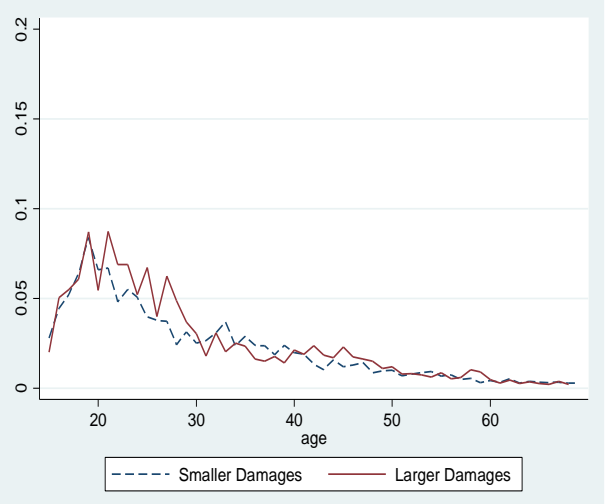

Non-disabled

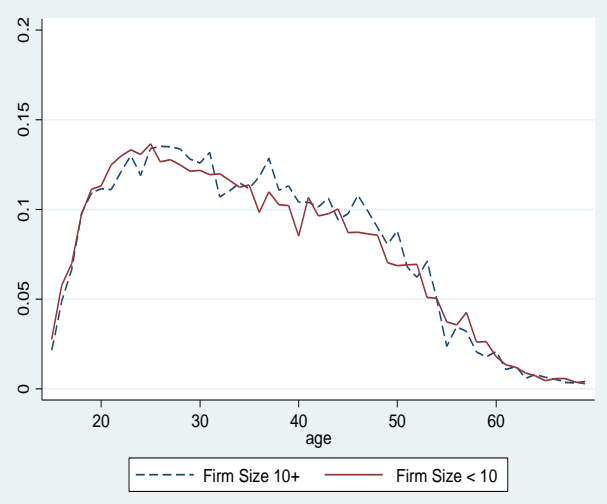

Disabled

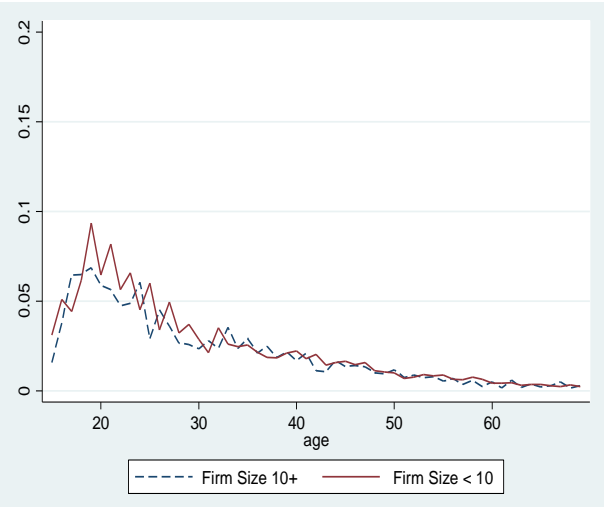

Notes: We use SIPP 1992, 1993, 1996, 2001, and 2004 for this analysis, so the sample period for this analysis is January, 1992 through December, 2007. Maine, Vermont, North Dakota, South Dakota, and Wyoming are deleted from the sample from SIPP 1992, 1993, 1996, and 2001 because they are not uniquely identified. We use probit models to calculate the predicted hiring probability for each age in years conditional on respondents being not working at $\mathrm{t}-1$. The models are estimated separately for the non-disabled and the disabled. We restrict the sample to adult males who are 15 or older and use person-level SIPP sampling weights. Each specification includes year fixed effects, single-year age dummy variables, and interactions between these age dummy variables and a dummy variable for the stronger disability discrimination protection indicated in the graph. The individual level controls include education, marital status, SMSA status, and race. Education includes high school graduate, some college, and college; marital status includes married, widowed, divorced; SMSA status includes metropolitan, and not-identified; race includes black, Asian, or other. All analyses include a dummy variable whether the hiring occurred during the last month of each wave to control for the seam bias. The predicted probability of hiring at each age is evaluated at the sample means of the controls. See the notes to Figure 1 for the definition of disability in the SIPP. 
Table 1: State Disability and Age Discrimination Laws, 2008

\begin{tabular}{|c|c|c|c|c|c|}
\hline \multirow[b]{2}{*}{ State } & \multicolumn{3}{|c|}{ Disability discrimination laws } & \multicolumn{2}{|c|}{ Age discrimination laws } \\
\hline & $\begin{array}{l}\text { Minimum } \\
\text { firm size }\end{array}$ & $\begin{array}{l}\text { Broader definition } \\
\text { of disability }\end{array}$ & $\begin{array}{l}\text { Larger damages } \\
\text { than ADA }\end{array}$ & $\begin{array}{l}\text { Minimum } \\
\text { firm size }\end{array}$ & $\begin{array}{c}\text { Larger damages } \\
\text { than ADEA }\end{array}$ \\
\hline Alabama & No law & No law & No law & 20 & No \\
\hline Alaska & 1 & No & Yes & 1 & Yes \\
\hline Arizona & 15 & No & No (no punitive) & 15 & No \\
\hline Arkansas & 9 & No & No (same as ADA) & No law & No law \\
\hline California & 5 & No (“limits” only, eff. 2001) & Yes (uncapped) & 5 & Yes \\
\hline Colorado & 1 & No & No (same as ADA) & 1 & No \\
\hline Connecticut & 3 & Yes & No (no punitive) & 3 & No \\
\hline Delaware & 15 & No & No (same as ADA) & 4 & Yes \\
\hline D.C. & 1 & No & Yes (uncapped) & 1 & Yes \\
\hline Florida & 15 & No & No (punitive capped at $\$ 100 \mathrm{k}$ ) & 15 & Yes \\
\hline Georgia & 15 & No & No (no punitive) & 1 & No \\
\hline Hawaii & 1 & No & Yes (uncapped) & 1 & Yes \\
\hline Idaho & 5 & No & No (punitive capped at $\$ 10 \mathrm{k}$ ) & 5 & Yes \\
\hline Illinois & 1 & Yes & No (no punitive) & 15 & Yes \\
\hline Indiana & $\begin{array}{l}15 \text { ( } 25 \text { before } \\
\text { July } 25,1994)\end{array}$ & No & No (no punitive) & 1 & No \\
\hline Iowa & 4 & No & No (no punitive) & 4 & Yes \\
\hline Kansas & 4 & No & No (damages capped at \$2k) & 4 & Yes \\
\hline Kentucky & 15 & No & No (no punitive) & 8 & Yes \\
\hline Louisiana & 20 & No & No (no punitive) & 20 & Yes \\
\hline Maine & 1 & No & Yes & 1 & Yes \\
\hline Maryland & 15 & No & No (same as ADA) & 15 & Yes \\
\hline Massachusetts & 6 & No & Yes (uncapped) & 6 & Yes \\
\hline Michigan & 1 & No & No (no punitive) & 1 & Yes \\
\hline Minnesota & 1 & No (“materially limits” only) & No (punitive capped at $\$ 25 \mathrm{k}$ ) & 1 & Yes \\
\hline Mississippi & No law & No law & No law & No law & No law \\
\hline Missouri & 6 & No & Yes (uncapped) & 6 & Yes \\
\hline Montana & 1 & No & No (no punitive) & 1 & Yes \\
\hline Nebraska & 15 & No & No (no punitive) & 20 & No \\
\hline Nevada & 15 & No & Yes & 15 & No \\
\hline New Hampshire & 6 & No & No (no punitive) & 6 & Yes \\
\hline New Jersey & 1 & Yes & Yes (uncapped) & 1 & Yes \\
\hline New Mexico & 4 & No & No (no punitive) & 4 & Yes \\
\hline New York & 4 & Yes & No (no punitive) & 4 & Yes \\
\hline North Carolina & 15 & No & Yes & 15 & No \\
\hline North Dakota & 1 & No & No (no damages) & 1 & No \\
\hline Ohio & 4 & No & Yes (uncapped) & 4 & Yes \\
\hline Oklahoma & 15 & No & No (no punitive) & 15 & No \\
\hline Oregon & 6 & No & Yes (uncapped) & 1 & Yes \\
\hline Pennsylvania & 4 & No & No (no punitive) & 4 & No \\
\hline Rhode Island & 4 & No & Yes (uncapped) & 4 & Yes \\
\hline South Carolina & 15 & No & No (same as ADA) & 15 & No \\
\hline South Dakota & 1 & No & No (no punitive) & No law & No law \\
\hline Tennessee & 8 & No & No (no punitive) & 8 & Yes \\
\hline Texas & 15 & No & No (same as ADA) & 15 & Yes \\
\hline Utah & 15 & No & No (no punitive) & 15 & No \\
\hline Vermont & 1 & No & $\begin{array}{l}\text { Yes (uncapped eff. May 13, } \\
\text { 1999, previously no punitive } \\
\text { damages) }\end{array}$ & 1 & Yes \\
\hline Virginia & 1 & No & No (no punitive) & 6 & No \\
\hline Washington & 8 & Yes (eff. May 4, 2007) & No (no punitive) & 8 & Yes \\
\hline West Virginia & 12 & No & Yes (uncapped) & 12 & No \\
\hline Wisconsin & 1 & No & No (no damages) & 1 & No \\
\hline Wyoming & 2 & No & No (no punitive) & 2 & No \\
\hline
\end{tabular}

Notes: For the states listed as "Yes" under Larger Damages than ADA, but not uncapped, details are as follow: AK - uncapped compensatory damages, punitive damages capped above ADA levels; ME - exceeds ADA cap for firms of 201+ employees; NV - uncapped compensatory damages except against government, punitive damages capped at maximum of \$300k and three times compensatory damages; NC - uncapped compensatory damages except against government, punitive damages capped at maximum of $\$ 250 \mathrm{k}$ and three times compensatory damages. 
Table 2: HRS and SIPP Descriptive Statistics

\begin{tabular}{|c|c|c|c|c|c|c|c|}
\hline & \multicolumn{2}{|l|}{ HRS } & & \multicolumn{4}{|c|}{ SIPP } \\
\hline & \multicolumn{2}{|c|}{ Age $53-69$} & & \multicolumn{2}{|c|}{ Full sample (age 15 - 69) } & \multicolumn{2}{|c|}{ Age $53-69$} \\
\hline & $\begin{array}{c}\text { Non-disabled } \\
\text { (1) }\end{array}$ & $\begin{array}{c}\text { Disabled } \\
\text { (2) }\end{array}$ & & $\begin{array}{c}\text { Non-disabled } \\
\text { (1) }\end{array}$ & $\begin{array}{l}\text { Disabled } \\
\text { (2) }\end{array}$ & $\begin{array}{c}\text { Non-disabled } \\
\text { (1) }\end{array}$ & $\begin{array}{c}\text { Disabled } \\
\text { (2) }\end{array}$ \\
\hline \multicolumn{8}{|l|}{ Dependent variable: } \\
\hline $\begin{array}{l}\text { Hired from non- } \\
\text { employment }\end{array}$ & $\begin{array}{c}0.217 \\
(0.008)\end{array}$ & $\begin{array}{c}0.079 \\
(0.005)\end{array}$ & $\begin{array}{l}\text { Hired from non- } \\
\text { employment }\end{array}$ & $\begin{array}{c}0.067 \\
(0.0004)\end{array}$ & $\begin{array}{c}0.016 \\
(0.0003)\end{array}$ & $\begin{array}{c}0.018 \\
(0.0004)\end{array}$ & $\begin{array}{c}0.006 \\
(0.0002)\end{array}$ \\
\hline \multicolumn{8}{|l|}{ Individual-level controls: } \\
\hline High school & $\begin{array}{c}0.355 \\
(0.008)\end{array}$ & $\begin{array}{c}0.380 \\
(0.009)\end{array}$ & High school & $\begin{array}{c}0.253 \\
(0.001)\end{array}$ & $\begin{array}{c}0.339 \\
(0.001)\end{array}$ & $\begin{array}{c}0.330 \\
(0.001)\end{array}$ & $\begin{array}{c}0.315 \\
(0.002)\end{array}$ \\
\hline Some college & $\begin{array}{c}0.227 \\
(0.076)\end{array}$ & $\begin{array}{c}0.192 \\
(0.008)\end{array}$ & Some college & $\begin{array}{c}0.185 \\
(0.001)\end{array}$ & $\begin{array}{c}0.168 \\
(0.001)\end{array}$ & $\begin{array}{c}0.196 \\
(0.001)\end{array}$ & $\begin{array}{c}0.158 \\
(0.001)\end{array}$ \\
\hline College & $\begin{array}{c}0.256 \\
(0.008)\end{array}$ & $\begin{array}{c}0.118 \\
(0.006)\end{array}$ & College & $\begin{array}{c}0.116 \\
(0.0005)\end{array}$ & $\begin{array}{c}0.066 \\
(0.001)\end{array}$ & $\begin{array}{c}0.223 \\
(0.001)\end{array}$ & $\begin{array}{c}0.083 \\
(0.001)\end{array}$ \\
\hline Partnered (Unmarried) & $\begin{array}{c}0.044 \\
(0.004)\end{array}$ & $\begin{array}{c}0.048 \\
(0.005)\end{array}$ & Married & $\begin{array}{c}0.316 \\
(0.001)\end{array}$ & $\begin{array}{c}0.467 \\
(0.001)\end{array}$ & $\begin{array}{c}0.778 \\
(0.001)\end{array}$ & $\begin{array}{c}0.659 \\
(0.002)\end{array}$ \\
\hline Divorced & $\begin{array}{c}0.164 \\
(0.007)\end{array}$ & $\begin{array}{c}0.239 \\
(0.009)\end{array}$ & Widow & $\begin{array}{c}0.016 \\
(0.0002)\end{array}$ & $\begin{array}{c}0.029 \\
(0.0004)\end{array}$ & $\begin{array}{c}0.054 \\
(0.001)\end{array}$ & $\begin{array}{c}0.054 \\
(0.001)\end{array}$ \\
\hline Single & $\begin{array}{c}0.048 \\
(0.005)\end{array}$ & $\begin{array}{c}0.062 \\
(0.005)\end{array}$ & Divorced & $\begin{array}{c}0.073 \\
(0.0004)\end{array}$ & $\begin{array}{c}0.189 \\
(0.001)\end{array}$ & $\begin{array}{c}0.110 \\
(0.001)\end{array}$ & $\begin{array}{c}0.195 \\
(0.001)\end{array}$ \\
\hline Black & $\begin{array}{c}0.081 \\
(0.004)\end{array}$ & $\begin{array}{c}0.154 \\
(0.006)\end{array}$ & Black & $\begin{array}{c}0.173 \\
(0.001)\end{array}$ & $\begin{array}{c}0.199 \\
(0.001)\end{array}$ & $\begin{array}{c}0.091 \\
(0.001)\end{array}$ & $\begin{array}{c}0.144 \\
(0.001)\end{array}$ \\
\hline Other race & $\begin{array}{c}0.032 \\
(0.003)\end{array}$ & $\begin{array}{c}0.047 \\
(0.004)\end{array}$ & Asian & $\begin{array}{c}0.045 \\
(0.0003)\end{array}$ & $\begin{array}{c}0.022 \\
(0.0003)\end{array}$ & $\begin{array}{c}0.024 \\
(0.0004)\end{array}$ & $\begin{array}{c}0.023 \\
(0.001)\end{array}$ \\
\hline Suburban & $\begin{array}{c}0.234 \\
(0.007)\end{array}$ & $\begin{array}{c}0.246 \\
(0.008)\end{array}$ & Other race & $\begin{array}{c}0.011 \\
(0.0001)\end{array}$ & $\begin{array}{c}0.017 \\
(0.0003)\end{array}$ & $\begin{array}{c}0.005 \\
(0.0001)\end{array}$ & $\begin{array}{c}0.015 \\
(0.0004)\end{array}$ \\
\hline Ex-urban & $\begin{array}{c}0.314 \\
(0.008)\end{array}$ & $\begin{array}{c}0.394 \\
(0.009)\end{array}$ & Metro & $\begin{array}{c}0.781 \\
(0.001)\end{array}$ & $\begin{array}{c}0.716 \\
(0.001)\end{array}$ & $\begin{array}{c}0.750 \\
(0.001)\end{array}$ & $\begin{array}{c}0.698 \\
(0.002)\end{array}$ \\
\hline & & & On seam & $\begin{array}{c}0.262 \\
(0.001)\end{array}$ & $\begin{array}{c}0.262 \\
(0.001)\end{array}$ & $\begin{array}{c}0.260 \\
(0.001)\end{array}$ & $\begin{array}{c}0.262 \\
(0.001)\end{array}$ \\
\hline $\mathrm{N}$ & 5,240 & 4,802 & $\mathrm{~N}$ & 744,365 & 311,272 & 204,456 & 152,736 \\
\hline
\end{tabular}

Notes: Standard errors of means are reported in parentheses. Person-level sampling weights are used. 
Table 3: Estimation Results and Significance Tests for Disability Discrimination Law Provisions, Hiring from Non-Employment

\begin{tabular}{|c|c|c|c|c|c|c|c|c|c|c|c|c|c|}
\hline & & \multicolumn{4}{|c|}{ Broader definition of disability } & \multicolumn{4}{|c|}{ Larger damages } & \multicolumn{4}{|c|}{ Firm-size minimum $<10$} \\
\hline & & \multicolumn{2}{|c|}{$\underline{\mathrm{HRS}}$} & \multicolumn{2}{|c|}{ SIPP } & \multicolumn{2}{|c|}{ HRS } & \multicolumn{2}{|c|}{ SIPP } & \multicolumn{2}{|c|}{$\underline{\mathrm{HRS}}$} & \multicolumn{2}{|c|}{ SIPP } \\
\hline & & $\begin{array}{c}\text { Non- } \\
\text { disabled } \\
(1) \\
\end{array}$ & $\begin{array}{c}\text { Disabled } \\
(2) \\
\end{array}$ & $\begin{array}{c}\text { Non- } \\
\text { disabled } \\
(3) \\
\end{array}$ & $\begin{array}{c}\text { Disabled } \\
(4)\end{array}$ & $\begin{array}{c}\text { Non- } \\
\text { disabled } \\
(5)\end{array}$ & $\begin{array}{c}\text { Disabled } \\
(6) \\
\end{array}$ & $\begin{array}{c}\text { Non- } \\
\text { disabled } \\
(7) \\
\end{array}$ & $\begin{array}{c}\text { Disabled } \\
(8)\end{array}$ & $\begin{array}{c}\text { Non- } \\
\text { disabled } \\
(9) \\
\end{array}$ & $\begin{array}{c}\text { Disabled } \\
(10)\end{array}$ & $\begin{array}{c}\text { Non- } \\
\text { disabled } \\
(11) \\
\end{array}$ & $\begin{array}{c}\text { Disabled } \\
(12) \\
\end{array}$ \\
\hline Age $20-29$ & $\begin{array}{l}\text { Avg. diff. } \\
\text { \% pos. } \\
\text { p-value }\end{array}$ & $\cdots$ & $\cdots$ & $\begin{array}{c}-0.025 \\
0 \% \\
0.000\end{array}$ & $\begin{array}{c}-0.004 \\
30 \% \\
0.014\end{array}$ & $\ldots$ & $\ldots$ & $\begin{array}{c}0.0002 \\
50 \% \\
0.053\end{array}$ & $\begin{array}{c}0.013 \\
90 \% \\
0.032\end{array}$ & $\ldots$ & $\ldots$ & $\begin{array}{c}0.001 \\
60 \% \\
0.076\end{array}$ & $\begin{array}{c}0.009 \\
80 \% \\
0.026\end{array}$ \\
\hline Age 30-39 & $\begin{array}{c}\text { Avg. diff. } \\
\text { \% pos. } \\
\text { p-value }\end{array}$ & $\ldots$ & $\ldots$ & $\begin{array}{c}-0.010 \\
40 \% \\
0.000\end{array}$ & $\begin{array}{c}0.003 \\
70 \% \\
0.000\end{array}$ & $\ldots$ & $\ldots$ & $\begin{array}{c}-0.005 \\
20 \% \\
0.027\end{array}$ & $\begin{array}{c}-0.005 \\
20 \% \\
0.218\end{array}$ & $\ldots$ & $\ldots$ & $\begin{array}{c}-0.006 \\
30 \% \\
0.016\end{array}$ & $\begin{array}{c}-0.001 \\
40 \% \\
0.578\end{array}$ \\
\hline Age $40-49$ & $\begin{array}{c}\text { Avg. diff. } \\
\text { \% pos. } \\
\text { p-value }\end{array}$ & $\ldots$ & $\ldots$ & $\begin{array}{c}-0.015 \\
10 \% \\
0.000\end{array}$ & $\begin{array}{c}-0.002 \\
40 \% \\
0.000\end{array}$ & $\ldots$ & $\ldots$ & $\begin{array}{c}-0.010 \\
30 \% \\
0.126\end{array}$ & $\begin{array}{c}0.005 \\
90 \% \\
0.131\end{array}$ & $\ldots$ & $\ldots$ & $\begin{array}{c}-0.008 \\
20 \% \\
0.005\end{array}$ & $\begin{array}{c}0.002 \\
80 \% \\
0.456\end{array}$ \\
\hline Age 50-61 & $\begin{array}{c}\text { Avg. diff. } \\
\text { \% pos. } \\
\text { p-value }\end{array}$ & $\ldots$ & $\ldots$ & $\begin{array}{c}-0.002 \\
33.3 \% \\
0.000\end{array}$ & $\begin{array}{c}0.001 \\
67.7 \% \\
0.000\end{array}$ & $\ldots$ & $\ldots$ & $\begin{array}{c}0.0001 \\
50 \% \\
0.000\end{array}$ & $\begin{array}{c}0.001 \\
66.7 \% \\
0.001\end{array}$ & $\ldots$ & $\ldots$ & $\begin{array}{c}0.001 \\
75 \% \\
0.000\end{array}$ & $\begin{array}{c}0.001 \\
58.3 \% \\
0.102\end{array}$ \\
\hline Age 62-69 & $\begin{array}{c}\text { Avg. diff. } \\
\text { \% pos. } \\
\text { p-value }\end{array}$ & $\begin{array}{c}-0.130 \\
37.5 \% \\
0.694\end{array}$ & $\begin{array}{c}-0.230 \\
25.0 \% \\
0.396\end{array}$ & $\begin{array}{c}0.0001 \\
75 \% \\
0.000\end{array}$ & $\begin{array}{c}-0.002 \\
25 \% \\
0.000\end{array}$ & $\begin{array}{c}-0.085 \\
12.5 \% \\
0.860\end{array}$ & $\begin{array}{c}-0.151 \\
37.5 \% \\
0.504\end{array}$ & $\begin{array}{c}0.0004 \\
75 \% \\
0.260\end{array}$ & $\begin{array}{c}-0.0005 \\
25 \% \\
0.974\end{array}$ & $\begin{array}{c}-0.058 \\
25 \% \\
0.342\end{array}$ & $\begin{array}{c}-0.005 \\
37.5 \% \\
0.115\end{array}$ & $\begin{array}{c}0.0002 \\
50 \% \\
0.000\end{array}$ & $\begin{array}{c}0.000 \\
50 \% \\
0.194\end{array}$ \\
\hline Age 40-52 & $\begin{array}{c}\text { Avg. diff. } \\
\% \text { pos. } \\
\text { p-value }\end{array}$ & .. & $\ldots$ & $\begin{array}{c}-0.012 \\
15.4 \% \\
0.000\end{array}$ & $\begin{array}{c}-0.001 \\
53.8 \% \\
0.000\end{array}$ & $\ldots$ & $\ldots$ & $\begin{array}{c}-0.006 \\
38.5 \% \\
0.000\end{array}$ & $\begin{array}{c}0.004 \\
92.3 \% \\
0.093\end{array}$ & $\ldots$ & $\ldots$ & $\begin{array}{c}-0.007 \\
30.8 \% \\
0.000\end{array}$ & $\begin{array}{c}0.001 \\
61.5 \% \\
0.598\end{array}$ \\
\hline Age 53-61 & $\begin{array}{c}\text { Avg. diff. } \\
\text { \% pos. } \\
\text { p-value }\end{array}$ & $\begin{array}{c}0.020 \\
66.7 \% \\
0.539\end{array}$ & $\begin{array}{c}-0.100 \\
28.6 \% \\
0.509\end{array}$ & $\begin{array}{c}-0.002 \\
33.3 \% \\
0.000\end{array}$ & $\begin{array}{c}0.0003 \\
55.6 \% \\
0.000\end{array}$ & $\begin{array}{c}-0.019 \\
44.4 \% \\
0.418\end{array}$ & $\begin{array}{c}0.033 \\
50 \% \\
0.976\end{array}$ & $\begin{array}{c}-0.003 \\
44.4 \% \\
0.000\end{array}$ & $\begin{array}{c}0.001 \\
55.6 \% \\
0.003\end{array}$ & $\begin{array}{c}0.138 \\
66.7 \% \\
0.808\end{array}$ & $\begin{array}{c}-0.111 \\
44.4 \% \\
0.420\end{array}$ & $\begin{array}{c}0.002 \\
77.8 \% \\
0.000\end{array}$ & $\begin{array}{c}0.002 \\
77.8 \% \\
0.157\end{array}$ \\
\hline Age 53-69 & $\begin{array}{c}\text { Avg. diff. } \\
\text { \% pos. } \\
\text { p-value }\end{array}$ & $\begin{array}{c}-0.050 \\
52.9 \% \\
0.704 \\
\end{array}$ & $\begin{array}{c}-0.169 \\
26.7 \% \\
0.469 \\
\end{array}$ & $\begin{array}{c}-0.001 \\
52.9 \% \\
0.000\end{array}$ & $\begin{array}{c}-0.001 \\
41.2 \% \\
0.000 \\
\end{array}$ & $\begin{array}{c}-0.050 \\
29.4 \% \\
0.729 \\
\end{array}$ & $\begin{array}{c}-0.059 \\
43.8 \% \\
0.890 \\
\end{array}$ & $\begin{array}{c}-0.001 \\
58.8 \% \\
0.000 \\
\end{array}$ & $\begin{array}{c}0.0002 \\
41.2 \% \\
0.001 \\
\end{array}$ & $\begin{array}{c}0.045 \\
47.1 \% \\
0.641 \\
\end{array}$ & $\begin{array}{c}-0.061 \\
41.2 \% \\
0.184 \\
\end{array}$ & $\begin{array}{c}0.001 \\
64.7 \% \\
0.000 \\
\end{array}$ & $\begin{array}{c}0.001 \\
64.7 \% \\
0.016\end{array}$ \\
\hline
\end{tabular}

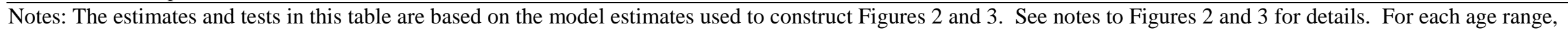

in each entry the table reports: (1) the average across the covered ages of the estimated differences in hiring rates between states with stronger and weaker disability discrimination laws; (2) the share of ages in the range for which the estimated hiring rate is higher with the stronger law; and (3) p-values for a joint (Wald) test of no difference for each age in the range between states with and without the stronger law. 
Table 4: Estimation Results and Significance Tests for Disability Discrimination Law Provisions, Hiring from Non-Employment, Substituting Fair or Bad Health as a Disability Measure

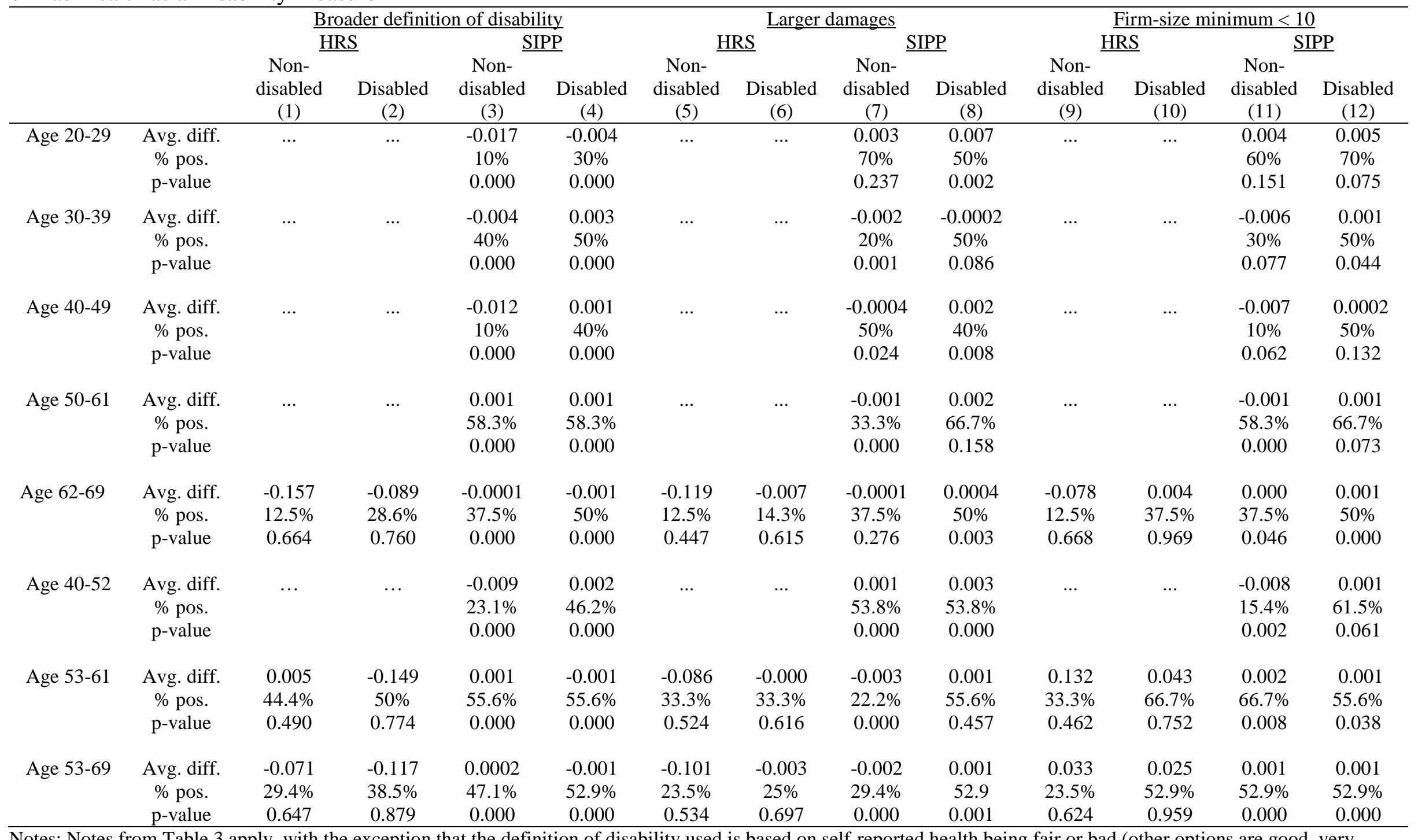

Notes: Notes from Table 3 apply, with the exception that the definition of disability used is based on self-reported health being fair or bad (other options are good, very good, or excellent) 
Table 5: Difference-in-Differences Estimates of Effects of Stronger Disability Discrimination Laws on Hiring of Non-Disabled Older Workers, SIPP Data, Hiring from Non-Employment

\begin{tabular}{|c|c|c|c|c|c|c|c|c|}
\hline & (1) & (2) & (3) & (4) & (5) & (6) & (7) & (8) \\
\hline Age $\geq 50 \times$ broader & $0.015^{* *}$ & $\ldots$ & ... & $0.017^{*}$ & $0.014^{* *}$ & $\ldots$ & $\ldots$ & $0.019^{*}$ \\
\hline definition of disability & $(0.007)$ & & & $(0.009)$ & $(0.006)$ & & & $(0.009)$ \\
\hline Age $\geq 50 \times$ larger damages & $\ldots$ & $\begin{array}{l}0.009^{* *} \\
(0.005)\end{array}$ & $\ldots$ & $\begin{array}{l}0.011^{* *} \\
(0.006)\end{array}$ & $\ldots$ & $\begin{array}{c}0.008 \\
(0.006)\end{array}$ & $\ldots$ & $\begin{array}{l}0.011^{*} \\
(0.006)\end{array}$ \\
\hline Age $\geq 50 \times$ firm size $<10$ & $\cdots$ & $\cdots$ & $\begin{array}{c}0.007 \\
(0.005)\end{array}$ & $\begin{array}{l}-0.001 \\
(0.005)\end{array}$ & .. & $\ldots$ & $\begin{array}{c}0.004 \\
(0.005)\end{array}$ & $\begin{array}{l}-0.006 \\
(0.006)\end{array}$ \\
\hline $\begin{array}{l}\text { Age } \geq 50 \times \text { age disc. larger } \\
\text { damages }\end{array}$ & $\cdots$ & $\cdots$ & $\cdots$ & $\cdots$ & $\begin{array}{l}0.0003 \\
(0.005)\end{array}$ & $\begin{array}{c}0.001 \\
(0.005)\end{array}$ & $\begin{array}{c}0.002 \\
(0.005)\end{array}$ & $\begin{array}{l}-0.001 \\
(0.004)\end{array}$ \\
\hline $\begin{array}{l}\text { Age } \geq 50 \times \text { age disc. firm } \\
\text { size }<10\end{array}$ & $\cdots$ & $\cdots$ & $\cdots$ & $\cdots$ & $\begin{array}{c}0.006 \\
(0.004) \\
\end{array}$ & $\begin{array}{c}0.004 \\
(0.005) \\
\end{array}$ & $\begin{array}{c}0.004 \\
(0.004) \\
\end{array}$ & $\begin{array}{c}0.007 \\
(0.004) \\
\end{array}$ \\
\hline $\begin{array}{l}\text { Age } \geq 55 \times \text { broader } \\
\text { definition of disability }\end{array}$ & $\begin{array}{l}0.015^{* *} \\
(0.007)\end{array}$ & $\cdots$ & $\ldots$ & $\begin{array}{c}0.015^{*} \\
(0.008)\end{array}$ & $\begin{array}{l}0.014^{* *} \\
(0.006)\end{array}$ & $\ldots$ & $\cdots$ & $\begin{array}{l}0.018^{* *} \\
(0.009)\end{array}$ \\
\hline Age $\geq 55 \times$ larger damages & $\ldots$ & $\begin{array}{l}0.007^{*} \\
(0.004)\end{array}$ & $\cdots$ & $\begin{array}{c}0.008 \\
(0.005)\end{array}$ & $\cdots$ & $\begin{array}{c}0.006 \\
(0.006)\end{array}$ & $\cdots$ & $\begin{array}{c}0.009 \\
(0.006)\end{array}$ \\
\hline Age $\geq 55 \times$ firm size $<10$ & $\cdots$ & $\ldots$ & $\begin{array}{c}0.008 \\
(0.005)\end{array}$ & $\begin{array}{c}0.002 \\
(0.005)\end{array}$ & $\cdots$ & $\cdots$ & $\begin{array}{c}0.005 \\
(0.004)\end{array}$ & $\begin{array}{l}-0.004 \\
(0.005)\end{array}$ \\
\hline $\begin{array}{l}\text { Age } \geq 55 \times \text { age disc. larger } \\
\text { damages }\end{array}$ & $\cdots$ & $\cdots$ & $\cdots$ & $\cdots$ & $\begin{array}{l}-0.001 \\
(0.004)\end{array}$ & $\begin{array}{l}0.0002 \\
(0.005)\end{array}$ & $\begin{array}{l}0.0001 \\
(0.005)\end{array}$ & $\begin{array}{l}-0.003 \\
(0.004)\end{array}$ \\
\hline $\begin{array}{l}\text { Age } \geq 55 \times \text { age disc. firm } \\
\text { size }<10\end{array}$ & $\cdots$ & $\cdots$ & $\cdots$ & $\cdots$ & $\begin{array}{l}0.008^{*} \\
(0.004)\end{array}$ & $\begin{array}{c}0.007 \\
(0.006) \\
\end{array}$ & $\begin{array}{r}0.005 \\
(0.004) \\
\end{array}$ & $\begin{array}{l}0.009^{* *} \\
(0.004)\end{array}$ \\
\hline $\begin{array}{l}\text { Age } \geq 60 \times \text { broader } \\
\text { definition of disability }\end{array}$ & $\begin{array}{l}0.011^{* *} \\
(0.005)\end{array}$ & $\cdots$ & $\cdots$ & $\begin{array}{l}0.013^{* *} \\
(0.007)\end{array}$ & $\begin{array}{l}0.012^{* *} \\
(0.005)\end{array}$ & $\cdots$ & $\cdots$ & $\begin{array}{l}0.016^{* *} \\
(0.007)\end{array}$ \\
\hline Age $\geq 60 \times$ larger damages & $\ldots$ & $\begin{array}{l}0.007^{*} \\
(0.004)\end{array}$ & $\cdots$ & $\begin{array}{l}0.008^{* *} \\
(0.004)\end{array}$ & $\cdots$ & $\begin{array}{c}0.006 \\
(0.005)\end{array}$ & $\cdots$ & $\begin{array}{l}0.009^{* *} \\
(0.004)\end{array}$ \\
\hline Age $\geq 60 \times$ firm size $<10$ & $\cdots$ & $\cdots$ & $\begin{array}{c}0.003 \\
(0.004)\end{array}$ & $\begin{array}{l}-0.003 \\
(0.004)\end{array}$ & $\cdots$ & $\cdots$ & $\begin{array}{r}-0.0001 \\
(0.003)\end{array}$ & $\begin{array}{l}-0.009^{* *} \\
(0.004)\end{array}$ \\
\hline $\begin{array}{l}\text { Age } \geq 60 \times \text { age disc. larger } \\
\text { damages }\end{array}$ & $\cdots$ & $\cdots$ & $\cdots$ & $\cdots$ & $\begin{array}{l}-0.003 \\
(0.004)\end{array}$ & $\begin{array}{l}-0.002 \\
(0.004)\end{array}$ & $\begin{array}{l}-0.001 \\
(0.004)\end{array}$ & $\begin{array}{l}-0.004 \\
(0.003)\end{array}$ \\
\hline $\begin{array}{l}\text { Age } \geq 60 \times \text { age disc. firm } \\
\text { size }<10\end{array}$ & $\cdots$ & $\cdots$ & $\cdots$ & $\cdots$ & $\begin{array}{c}0.005 \\
(0.004)\end{array}$ & $\begin{array}{c}0.004 \\
(0.005)\end{array}$ & $\begin{array}{c}0.006 \\
(0.004)\end{array}$ & $\begin{array}{l}0.009^{* *} \\
(0.004)\end{array}$ \\
\hline $\mathrm{N}$ & 311,209 & 311,209 & 311,209 & 311,209 & 311,209 & 311,209 & 311,209 & 311,209 \\
\hline
\end{tabular}

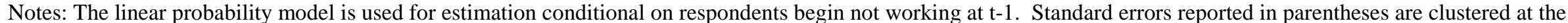

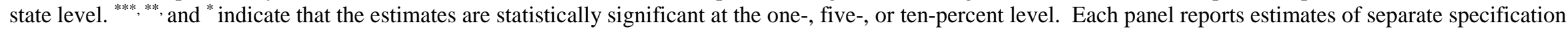

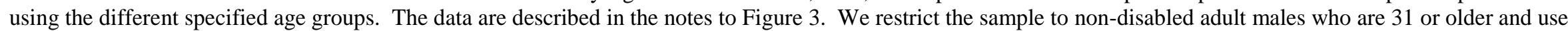
person-level SIPP sampling weights. Each specification includes state and year fixed effects, single-year age dummy variables, and the same individual-level controls

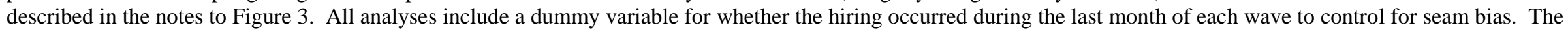
main effects of the discrimination law dummy variables are not reported as they are subsumed in the state fixed effects. There was a law change in Vermont for larger

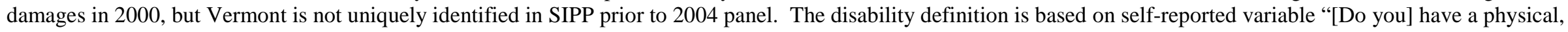
mental, or other health condition that limits the kind or amount of work [you] can do?” This question is asked only for those 69 years or younger. 
Table 6: Difference-in-Differences Estimates of Effects of Stronger Disability Discrimination Laws on Hiring of Non-Disabled Older Workers, SIPP Data, Hiring from Non-Employment, Substituting Fair or Bad Health as a Disability Measure

\begin{tabular}{|c|c|c|c|c|c|c|c|c|}
\hline & (1) & (2) & (3) & (4) & (5) & (6) & (7) & (8) \\
\hline $\begin{array}{l}\text { Age } \geq 50 \times \text { broader } \\
\text { definition of disability }\end{array}$ & $\begin{array}{r}0.010 \\
(0.008)\end{array}$ & $\ldots$ & $\ldots$ & $\begin{array}{c}0.009 \\
(0.009)\end{array}$ & $\begin{array}{c}0.009 \\
(0.008)\end{array}$ & $\ldots$ & $\ldots$ & $\begin{array}{c}0.009 \\
(0.010)\end{array}$ \\
\hline $\begin{array}{l}\text { Age } \geq 50 \times \text { larger } \\
\text { damages }\end{array}$ & $\ldots$ & $\begin{array}{c}0.002 \\
(0.004)\end{array}$ & $\ldots$ & $\begin{array}{c}0.002 \\
(0.006)\end{array}$ & $\ldots$ & $\begin{array}{c}0.001 \\
(0.005)\end{array}$ & $\ldots$ & $\begin{array}{c}0.002 \\
(0.006)\end{array}$ \\
\hline Age $\geq 50 \times$ firm size $<10$ & $\ldots$ & $\ldots$ & $\begin{array}{c}0.006 \\
(0.004)\end{array}$ & $\begin{array}{c}0.003 \\
(0.005)\end{array}$ & $\ldots$ & $\ldots$ & $\begin{array}{c}0.006 \\
(0.004)\end{array}$ & $\begin{array}{c}0.002 \\
(0.006)\end{array}$ \\
\hline $\begin{array}{l}\text { Age } \geq 50 \times \text { age disc } \\
\text { larger damages }\end{array}$ & $\ldots$ & $\ldots$ & $\ldots$ & $\ldots$ & $\begin{array}{c}0.002 \\
(0.003)\end{array}$ & $\begin{array}{c}0.004 \\
(0.004)\end{array}$ & $\begin{array}{c}0.002 \\
(0.004)\end{array}$ & $\begin{array}{c}0.001 \\
(0.004)\end{array}$ \\
\hline $\begin{array}{l}\text { Age } \geq 50 \times \text { age disc. firm } \\
\text { size }<10\end{array}$ & $\ldots$ & $\ldots$ & $\ldots$ & $\ldots$ & $\begin{array}{c}0.003 \\
(0.003)\end{array}$ & $\begin{array}{c}0.003 \\
(0.004)\end{array}$ & $\begin{array}{l}-0.001 \\
(0.003)\end{array}$ & $\begin{array}{c}0.002 \\
(0.005)\end{array}$ \\
\hline $\begin{array}{l}\text { Age } \geq 55 \times \text { broader } \\
\text { definition of disability }\end{array}$ & $\begin{array}{r}0.009 \\
(0.008)\end{array}$ & $\ldots$ & $\ldots$ & $\begin{array}{c}0.007 \\
(0.009)\end{array}$ & $\begin{array}{c}0.008 \\
(0.008)\end{array}$ & $\ldots$ & $\ldots$ & $\begin{array}{r}0.008 \\
(0.010)\end{array}$ \\
\hline $\begin{array}{l}\text { Age } \geq 55 \times \text { larger } \\
\text { damages }\end{array}$ & $\ldots$ & $\begin{array}{c}0.003 \\
(0.005)\end{array}$ & $\ldots$ & $\begin{array}{c}0.002 \\
(0.006)\end{array}$ & $\ldots$ & $\begin{array}{c}0.001 \\
(0.006)\end{array}$ & $\ldots$ & $\begin{array}{c}0.002 \\
(0.006)\end{array}$ \\
\hline Age $\geq 55 \times$ firm size $<10$ & $\ldots$ & $\ldots$ & $\begin{array}{c}0.008 \\
(0.005)\end{array}$ & $\begin{array}{c}0.005 \\
(0.005)\end{array}$ & $\ldots$ & $\ldots$ & $\begin{array}{l}0.007^{* *} \\
(0.004)\end{array}$ & $\begin{array}{c}0.003 \\
(0.006)\end{array}$ \\
\hline $\begin{array}{l}\text { Age } \geq 55 \times \text { age disc } \\
\text { larger damages }\end{array}$ & $\cdots$ & $\ldots$ & $\ldots$ & $\ldots$ & $\begin{array}{l}-0.0005 \\
(0.004)\end{array}$ & $\begin{array}{c}0.001 \\
(0.005)\end{array}$ & $\begin{array}{l}-0.0005 \\
(0.004)\end{array}$ & $\begin{array}{l}-0.002 \\
(0.004)\end{array}$ \\
\hline $\begin{array}{l}\text { Age } \geq 55 \times \text { age disc. firm } \\
\text { size }<10\end{array}$ & $\ldots$ & $\ldots$ & $\ldots$ & $\ldots$ & $\begin{array}{c}0.005 \\
(0.004)\end{array}$ & $\begin{array}{c}0.005 \\
(0.005)\end{array}$ & $\begin{array}{r}0.0005 \\
(0.003)\end{array}$ & $\begin{array}{l}0.003 \\
(0.004)\end{array}$ \\
\hline $\begin{array}{l}\text { Age } \geq 60 \times \text { broader } \\
\text { definition of disability }\end{array}$ & $\begin{array}{r}0.006 \\
(0.007)\end{array}$ & $\ldots$ & $\ldots$ & $\begin{array}{c}0.006 \\
(0.007)\end{array}$ & $\begin{array}{r}0.006 \\
(0.006)\end{array}$ & $\ldots$ & $\ldots$ & $\begin{array}{c}0.007 \\
(0.008)\end{array}$ \\
\hline $\begin{array}{l}\text { Age } \geq 60 \times \text { larger } \\
\text { damages }\end{array}$ & $\ldots$ & $\begin{array}{c}0.002 \\
(0.003)\end{array}$ & $\ldots$ & $\begin{array}{c}0.002 \\
(0.004)\end{array}$ & $\ldots$ & $\begin{array}{c}0.001 \\
(0.005)\end{array}$ & $\ldots$ & $\begin{array}{c}0.003 \\
(0.005)\end{array}$ \\
\hline Age $\geq 60 \times$ firm size $<10$ & $\ldots$ & $\ldots$ & $\begin{array}{c}0.004 \\
(0.004)\end{array}$ & $\begin{array}{c}0.002 \\
(0.004)\end{array}$ & $\ldots$ & $\ldots$ & $\begin{array}{c}0.002 \\
(0.003)\end{array}$ & $\begin{array}{l}-0.001 \\
(0.004)\end{array}$ \\
\hline $\begin{array}{l}\text { Age } \geq 60 \times \text { age disc } \\
\text { larger damages }\end{array}$ & $\ldots$ & $\ldots$ & $\ldots$ & $\ldots$ & $\begin{array}{l}-0.002 \\
(0.003)\end{array}$ & $\begin{array}{l}-0.001 \\
(0.004)\end{array}$ & $\begin{array}{l}-0.002 \\
(0.003)\end{array}$ & $\begin{array}{l}-0.003 \\
(0.003)\end{array}$ \\
\hline $\begin{array}{l}\text { Age } \geq 60 \times \text { age disc. firm } \\
\text { size }<10\end{array}$ & $\ldots$ & $\ldots$ & $\ldots$ & $\ldots$ & $\begin{array}{c}0.004 \\
(0.003)\end{array}$ & $\begin{array}{c}0.004 \\
(0.004)\end{array}$ & $\begin{array}{c}0.003 \\
(0.003)\end{array}$ & $\begin{array}{c}0.005 \\
(0.004)\end{array}$ \\
\hline $\mathrm{N}$ & 322,697 & 322,697 & 322,697 & 322,697 & 322,697 & 322,697 & 322,697 & 322,697 \\
\hline
\end{tabular}

Notes: Notes from Table 5 apply, with the exception that the definition of disability used is based on self-reported health being fair or bad (other options are good, very good, or excellent). 
Does Protecting Older Workers from Discrimination Make It Harder to Get Hired?

Evidence from Disability Discrimination Laws:

Disability Laws Appendix 


\section{Coding of State Laws}

To study the effects of disability discrimination laws, we first needed to code up these laws. To do this, we followed the procedure developed in Neumark and Song (2013) to code state age discrimination laws. This required extensive background research on state statutes and their histories, culled from legal databases including Lexis-Nexis, Westlaw, and Hein Online, as well as many other sources. The first step in assembling information on state disability discrimination laws was to identify the appropriate state statute, which can be complicated because the disability discrimination law can be listed under various sections of state law (e.g., a fair employment act, a separate disability discrimination act). After the appropriate statute was identified, we traced the history of the statute using the legal databases to look for changes over time. In some cases we had to look beyond the statutes to information from state agencies, case law, or other sources.

Because it is complicated to read and interpret the law correctly based solely on statutes, we crosschecked our understanding of the statute with other legal references or treatises and additional sources of information on state laws. ${ }^{19}$ The other sources were also useful because of a further challenge in reading statutes. In particular, one section may define what a discriminatory act is, while other provisions may be delegated to the Civil Rights Commission, or the remedies may be listed under a different section of the statute.

To minimize inaccuracies, once all the necessary information was obtained from these sources, we attempted to compare and validate it using other sources. If information obtained from different sources matched, we were confident that the information was correct. In cases of what should be unambiguous information - in particular the minimum firm size for laws to apply - we use the information from the statute regardless. However, in cases of information that can be more easily misinterpreted from the statute, when we found discrepancies we turned to state agencies or other sources for corroborating information. We also examined case law, using the legal databases, to see if rulings established fixed features of the state laws that were not specified in the statute, such as damages allowed.

As a result of these efforts, we were able to fill in all the information on these laws for our sample period. The only possible exception is for damages. In particular, if our information on damages came not from statutes (since the statutes did not mention damages) but rather from case law or other sources, then we did not necessarily have an explicit "reading" on these damages in every year. But since our other sources cover many years, the only variation we could miss was some short-term change between the level of damages we get from other sources. We assume, though, that there is little or no such variation.

As noted in the main text, there are three major ways in which state disability discrimination laws can be stronger than the federal ADA. Here we provide some general discussion of these differences, and then we provide state-specific details.

The minimum firm size for the ADA to apply is 15 . We create an indicator variable equal to one if the firm size minimum is lower than 10 (i.e., substantially lower than the ADA minimum), and zero otherwise. When the firm size minimum is lower, more workers (and employers) are covered.

Defining disability is of course more complicated than defining other protected groups, like age, race, and sex, and the definition of disability differs across states. Most states adopt the same definition as the ADA, either explicitly or via case law. The ADA provides three routes for an individual to be considered disabled:

“The term "disability” means, with respect to an individual-

${ }^{19}$ These included Beegle and Stock (2003), Buckley and Green (2011, 2009, 2008, 2006, 2002, 1997), Colker and Milani (2002), DRI (2011), Green (1992), Long (2004), Perry (2011), and a 50-state survey of discrimination laws at http://www.navexglobal.com/sites/default/files/uploads/lb_Descrimination-50States.pdf (viewed September 22, 2014). 
(A) a physical or mental impairment that substantially limits one or more major life activities of such individual;

(B) a record of such an impairment; or

(C) being regarded as having such an impairment” (42 U.S. Code §12102 (1)).

Given that the definition of physical and mental impairment is quite broad, the "substantially limits" requirement can probably be thought of as the main criterion defining disability under the ADA and similar state laws. Moreover, the "substantially limits" phrase has been interpreted by the courts as quite restrictive $^{20}$. The U.S. Supreme Court, in the "Sutton Trilogy" of cases (Sutton v. United Airlines (119 S. Ct. 2139 (1999)), Murphy v. United Parcel Service, Inc. (119 S. Ct. 2133 (1999)), and Albertson's, Inc. v. Kirkingburg (119 S. Ct. 2162 (1999))), deemed individuals to be not disabled if mitigating measures, such as glasses or medication, made the limiting features of the disability dormant. A U.S. Court of Appeals, $4^{\text {th }}$ Circuit, decision also restricted episodic conditions, such as epilepsy, from being considered a disability in EEOC v. Sara Lee Corp., 237 F.3d 349 (4th Cir., 2001). ${ }^{21}$

Some states use a weaker criterion in this regard than the "substantially limits" requirement of the ADA under the first criterion above. In two states this is done by the statutes substituting "materially limits" (MN) or just "limits" (CA) for "substantially limits," with legal interpretations or statutes being explicit that this is a less stringent standard. Several states (CT, IL, NJ, NY, and WA) adopt an even laxer definition, considering an individual to be disabled if their impairment is medically diagnosed, regardless of whether the impairment substantially limits one or more major life activities. Long (2004) argues, as seems quite reasonable, that these medical definitions broaden coverage relative to the ADA. To capture this variation, we create a dichotomous variable called "broader definition" which equals one for states with the medical definition of disability, and zero otherwise. ${ }^{22}$

Damages are likely to play a major role in the strength of discrimination laws, based in part on evidence from age discrimination laws (Neumark and Song, 2013). The ADA caps the sum of compensatory and punitive damages per claimant based on firm size, as follows:

$$
\begin{array}{ll}
\text { 1. } & 15-100 \text { employees: } \$ \$ 50,000 \\
\text { 2. } & 101-200 \text { employees: } \$ 100,000 \\
\text { 3. } & 201-500 \text { employees: } \$ 200,000 \\
4 . & 500 \text { plus employees: } \$ 300,000 \text {. }
\end{array}
$$

Few states follow this exact schedule (AR, CO, DE, and MD from 2007 onward, SC, TX, WI prior to April 20, 2012). Fifteen states allow larger potential damages, either through higher caps (AK, ME, NV, NC) or, more commonly, through no caps at all on both compensatory and punitive damages (CA, DC, HI, MA, MO, NJ, OH, OR , RI, VT, and WV). We create a dichotomous variable called "larger damages," which equals one for the 15 states where potential damages exceed those under the ADA, and zero otherwise. Four states (FL, ID, KS, MN) have lower damage caps than the ADA, and two states (AL

\footnotetext{
${ }^{20}$ For example, Burgdorf (1997, p. 536-538) cites numerous cases stemming from numerous cases stemming from Forrisi v. Bowen, 794 F.2d 931, 934 (4th Cir. 1986), which interpreted the ADA to only cover the "truly disabled" and not those with more minor impairments.

21 These decisions were reversed by the ADA Amendments Act (ADAAA), effective in 2009, which is beyond our sample period. Under the ADAAA, states where the ADA's definition of disability prevailed became more like those states using a medical impairment definition, discussed next. In principle we could use data pre- and post2009 for identifying information on this dimension of variation in disability discrimination laws, but the confounding effects of the Great Recession make this unlikely to be informative.

${ }^{22}$ We also considered including the other states with laxer definitions (California and Minnesota) in the broader definition category, but decided not to because the definition in these states seems much closer to the ADA definition. Nonetheless, we verified that results with this alternative classification were similar.
} 
and MS) have no law (in which case we code the state as not having the stronger provision). There are 24 states with no punitive damages, most of which allow uncapped compensatory damages. We do not include these states in the larger damages category because compensatory damages require documentation and in many cases seem unlikely to be as large; an example might be medical bills if an employee was terminated unjustly, and dropped from a health insurance plan. Thus, punitive damages are likely more the driver of large judgments. ${ }^{23,24}$

Definition of Disability

Some state laws bypass the requirement that a mental or physical impairment "substantially limits" one or more major life activities. This occurs either by replacing "substantially limits" with either just "limits" (California) or "materially limits" (Minnesota), or by defining disability as a medical diagnosis (Connecticut, Illinois, New Jersey, New York, Washington effective May 4, 2007). These state laws are discussed in more detail below.

\section{California}

California's disability discrimination law is discussed in further detail by Button (2015) but we provide a summary here. California adopts a similar definition of disability to the ADA, but specifies in statute that the impairment must "limit" instead of "substantially limit" a major life activity. Although dropping the word "substantially" may seem trivial, this did in fact make establishing that a disability exists less burdensome, but not initially. The Prudence Kay Poppink Act took effect in California in 2001, and this act made it explicit that the "limits" requirement in California was less burdensome than the federal ADA. Before this act passed however, the "limits" requirement was interpreted in the same way as the federal ADA (Long, 2004). For example, in Colmenares v. Braemer Country Club, Inc., 63 P.3d 220, 223 (Cal. 2003), the plaintiff was deemed not disabled because his case preceded the Poppink Act, when California’s "limits" was interpreted the same as the ADA’s "substantially limits."

\section{Connecticut}

In Connecticut, a diagnosis of a physical or mental impairment makes the individual disabled under law, bypassing the "substantially limits" requirement. CONN. GEN. STAT. § 46a-51(15). states that “ 'Physically disabled' refers to any individual who has any chronic physical handicap, infirmity or impairment, whether congenital or resulting from bodily injury, organic processes or changes or from

${ }^{23}$ For reasons explained below, some of our analyses incorporate information on two features of state age discrimination laws - larger damages, and the firm-size cut-off - in some of our analyses. This information (from Neumark and Song, 2013) is listed in the last two columns of Table 1. As the table shows, firm-size minimums are similar for disability and age discrimination laws, but there are nine states that have a different minimum (AL, AR, DE, GA, KY, IN, LA, NE, and SD). With regard to damages, we focus on whether compensatory or punitive damages are allowed, which they are not under federal age discrimination law (the ADEA). Some states require proof of intent to discriminate in order for compensatory or punitive damages to be awarded, whereas others require "willful" violation. Because the federal law allows additional liquidated, non-punitive damages (double back pay and benefits) when there is "willful" violation, the question of whether the state requires intent or willful violation may seem to be potentially relevant in deciding whether a state law offers greater protection. However, willful violation is a much stricter standard than intent (Moberly, 1994). Moreover, compensatory or punitive damages are almost certainly greater than liquidated damages, and they can be much greater. As a consequence, a state law that provides compensatory or punitive damages, whether or not this requires proof of intent or willful violation, clearly entails stronger remedies than the federal law, so our classification captures whether either is allowed.

${ }^{24}$ In principle one might classify states with combinations of the three dimensions of laws tabulated in Table 1 as having the strongest laws. However, this would provide virtually no difference in variation, and hence almost no additional variation. As Table 1 shows, the set of states with the broader definition is quite small, and only one state (New Jersey) overlaps this dimension of state laws with larger damages. Similarly, for the overlap between broader definition and smaller firm size, only one state (Illinois) would differ. And finally, if we look at the overlap between larger damages and smaller firm size, only one state with larger damages leaves its firm size cutoff at 10 or greater (West Virginia); the independent variation in firm size cutoffs comes from the states that do not have larger damages. 
illness, including, but not limited to, epilepsy, deafness or hearing impairment or reliance on a wheelchair or other remedial appliance or device.”

Connecticut is even more explicit in its definition of mental disability (Long, 2004), as CONN. GEN. STAT. § 46a-51(20) states that “ 'Mental disability' refers to an individual who has a record of, or is regarded as having one or more mental disorders, as defined in the most recent edition of the American Psychiatric Association's ‘Diagnostic and Statistical Manual of Mental Disorders’ ”

\section{Illinois}

775 ILL. COMP. STAT. 5/1-103(I) defines a disability as “.... determinable physical or mental characteristic of a person, including, but not limited to, a determinable physical characteristic which necessitates the person's use of a guide, hearing or support dog, the history of such characteristic, or the perception of such characteristic by the person complained against, which may result from disease, injury, congenital condition of birth or functional disorder...”

\section{Minnesota}

Similar to California, MINN. STAT. § 363.01(12) defines disability as “....any condition or characteristic that renders a person a disabled person. A disabled person is any person who (1) has a physical, sensory, or mental impairment which materially limits one or more major life activities; (2) has a record of such an impairment; or (3) is regarded as having such an impairment." While the distinction between materially and substantially may seem trivial, Long (2004) notes that the Minnesota Supreme Court, in Sigurdson v. Carl Bolander \& Sons, Co., 532 N.W.2d 225, 228 n.3 (Minn. 1995), stated that the Minnesota definition is less stringent.

New Jersey

N.J. STAT. ANN. § 10:5-5(q) defines disability as a “...physical disability, infirmity, malformation or disfigurement which is caused by bodily injury, birth defect or illness including epilepsy and other seizure disorders, and which shall include, but not be limited to, any degree of paralysis, amputation, lack of physical coordination, blindness or visual impediment, deafness or hearing impediment, muteness or speech impediment or physical reliance on a service or guide dog, wheelchair, or other remedial appliance or device, or any mental, psychological or developmental disability, including autism spectrum disorders, resulting from anatomical, psychological, physiological or neurological conditions which prevents the normal exercise of any bodily or mental functions or is demonstrable, medically or psychologically, by accepted clinical or laboratory diagnostic techniques. Disability shall also mean AIDS or HIV infection.”

\section{New York}

New York's Executive Law § 292(21)(a) defines a disability as "a physical, mental or medical impairment resulting from anatomical, physiological, genetic or neurological conditions which prevents the exercise of a normal bodily function or is demonstrable by medically accepted clinical or laboratory diagnostic techniques." The requirement that the impairment be "demonstrable by medically accepted clinical or laboratory diagnostic techniques" bypasses the "substantially limits” requirement and makes New York disability discrimination law more broadly applicable (Long, 2004).

\section{Washington}

Washington's definition of disability was rather vague before an amendment, effective May 4, 2007, changed Washington's definition to follow a medical diagnosis definition like Connecticut, Illinois, New Jersey, and New York. Prior to this amendment, WASH. REV. CODE § 49.60 .180 prohibited discrimination on the basis of physical disability, but the term was not defined. Noting this, Long (2004) could not categorize Washington's laws and instead put them in a "miscellaneous" category. It appears that Washington's lack of definition caused courts to rely on the federal definition of disability, which 
included the "substantially limits" requirement. ${ }^{25}$ After the 2007 amendment, Washington law states that “ 'Disability' means the presence of a sensory, mental, or physical impairment that:

(i) Is medically cognizable or diagnosable; or

(ii) Exists as a record or history; or

(iii) Is perceived to exist whether or not it exists in fact” (Wash. Rev. Code $§ 49.60 .040$ (7)(a)).

\section{Compensatory and Punitive Damages}

As discussed in the main text, we classify 15 states as having damages that exceed those provided by the ADA. Of these 15 larger damages states, four states (AK, ME, NV, NC) have compensatory and/or punitive damage caps that exceed those of the ADA, while the remaining eleven (CA, DC, HI, MA, MO, $\mathrm{NJ}, \mathrm{OH}, \mathrm{OR}, \mathrm{RI}, \mathrm{VT}, \mathrm{WV}$ ) have compensatory and punitive damages that are both uncapped. Of the 36 states that we classify as not having damages that exceed the ADA, six states (AR, CO, DE, MD, SC, TX) have the exact same damage caps as the ADA, four (FL, ID, KS, MN) have lower damage caps, 24 do not allow punitive damages (AZ, CT, GA, IA, IL, IN, KY, LA, MI, MT, NE, NH, NM, NY, ND, OK, PA, SD, TN, UT, VA, WA, WI, WY), and two (AL, MS) do not have an employment non-discrimination law for disability.

\section{States with Uncapped Compensatory and Punitive Damages}

Ten states (CA, HI, MA, MO, NJ, OH, OR, RI, VT, and WV, plus DC) offer both compensatory and punitive damages that are uncapped. Determining that these damages were in fact uncapped was difficult. For all these states, statutes did not mention explicit caps on damages, nor was there explicit mention that damages were uncapped. While it seemed likely that these states allowed uncapped damages, we confirmed this conjecture with various sources.

\section{California}

California's employment non-discrimination law is vague as to what damages are available, and this had to be clarified in case law. As mentioned by DRI (2011, p. 27), the Fair Employment and Housing Act (Cal. Govt. Code §\$12900-12996) provides no statutory caps on civil damages. The case Commodore Home Sys., Inc. v. Superior Court, 32 Cal. 3d 211, 221 (1982) concluded that allowable damages fell under Cal. Civ. Code, $\S 3294$, which provides no caps. ${ }^{26}$

\section{District of Columbia}

As mentioned by DRI (2011, p. 67), DC law (D.C. Mun. Regs. 4 \$210-212) allows for both compensatory and punitive damages. Caps, or lack thereof, are not explicitly mentioned. DRI (2011, p. 67) confirms that there are in fact no caps.

\section{Hawaii}

Hawaii's employment non-discrimination law states that compensatory and punitive damages are available, but no caps, or lack thereof, are explicitly mentioned (HI ST § 378-5, HI ST § 368-17). DRI (2011, p. 97) confirms that there are in fact no caps.

\section{Massachusetts}

Massachusetts' employment non-discrimination law states that compensatory and punitive damages are available, but no caps, or lack thereof, are explicitly mentioned (MA ST 151B). These damages can only be obtained from trial court and not through the Massachusetts Commission Against Discrimination (DRI, 2011, p. 191) (Sperino, 2010).

\footnotetext{
${ }^{25}$ See Pulcino v. Fed. Express Corp., 9 P.3d 787, 794 (Wash. 2000) as discussed by Long (2004).

${ }^{26}$ See http://scocal.stanford.edu/opinion/commodore-home-systems-inc-v-superior-court-28300 (viewed February $2,015)$.
} 


\section{Missouri}

Missouri's employment non-discrimination law states that compensatory and punitive damages are available, but no caps, or lack thereof, are explicitly mentioned (MO ST 213). According to case law mentioned by DRI (2011, p. 223) “...the Missouri Courts of Appeals have indicated that, in most situations, the courts should not allow punitive damages in excess of a single digit ratio to actual damages. State ex rel. Bass Pro Outdoor World, LLC v. Schneider, 302 S.W.3d 103 (Mo. App. 2009). At least one court has held, however, that in appropriate circumstances a punitive damage award could significantly exceed a single digit ratio. Lynn v. TNT Logistics North America, Inc., 275 S.W.3d 304 (Mo. App. 2008)” (Sperino, 2010).

New Jersey

New Jersey's employment non-discrimination law states that "All remedies available in common law tort actions shall be available to prevailing plaintiffs" (N.J.S.A. 10:5-13). This includes compensatory and punitive damages (DRI, 2011, p. 254) but there is no explicit mention of caps, or lack thereof. Case law, such as Baker v. National State Bank, 801 A.2d 1158 (N.J. App. Div. 2002) indicates that these damages are uncapped (DRI, 2011, p. 253).

Ohio

According to DRI (2011, p. 311), uncapped compensatory and punitive damages are allowed under civil actions. These damages are capped if the case is handled by the Ohio Civil Rights Commission.

Oregon

Oregon's employment non-discrimination law states: "The court may award, in addition to the relief authorized under subsection (1) of this section, compensatory damages or $\$ 200$, whichever is greater, and punitive damages...” (OR ST § 659A.885(3)(a)). DRI (2011, p. 326) confirms that damages are uncapped, noting that there are caps only if the action is against a government entity.

\section{Rhode Island}

Rhode Island's employment non-discrimination law states that: "Any person with a disability who is the victim of discrimination prohibited by this chapter may bring an action in the Superior Court against the person or entity causing the discrimination for equitable relief, compensatory and/or punitive damages or for any other relief that the court deems appropriate” (RI ST § 42-87-4). DRI (2011, p. 352) confirms that there are no caps, but notes that judges may intervene in cases when juries wish to award punitive damages that are deemed excessive, as in Mazzaroppi v. Tocco, 533 A.2d 203 (R.I. 1987).

\section{Vermont}

Vermont's employment non-discrimination law states that: “Any person aggrieved by a violation of the provisions of this subchapter may bring an action in superior court seeking compensatory and punitive damages or equitable relief, including restraint of prohibited acts, restitution of wages or other benefits, reinstatement, costs, reasonable attorney's fees and other appropriate relief” (21 V.S.A. §495b). DRI (2011, p. 399) interprets this to mean that both compensatory and punitive damages are uncapped. The language "compensatory and punitive damages" was added by 1999, No. 19, §5. Before this, the statute just said "damages" and it was left ambiguous if punitive damages were covered. This question was settled in Fernot v. Crafts Inn, Inc., 895 F. Supp. 668, 682 (D. Vt. 1995), where it was deemed that punitive damages were not allowed. Thus, we interpret that while Vermont has consistently had uncapped compensatory damages, punitive damages only became available (uncapped) effective on the amendment's approval on May 13, 1999. Since we use annual data we code the change as effective 2000.

\section{West Virginia}

West Virginia's employment non-discrimination law does not directly state that compensatory and punitive damages are available. It states that remedies include: “...reinstatement or hiring of employees, granting of back pay or any other legal or equitable relief as the court deems appropriate. In actions 
brought under this section, the court in its discretion may award all or a portion of the costs of litigation, including reasonable attorney fees and witness fees, to the complainant” (W. Va. Code §5-11-13). DRI (2011, p. 428) deems punitive damages to be available, citing Haynes v. Rhone-Poulenc, Inc.,521 S.E.2d 331 (W. Va. 1999) as an example. The question of if compensatory damages were available was settled in State Human Rights Commission v. Pauley, 212 S.E.2d 77 (W. Va. 1975), where the West Virginia Supreme Court deemed compensatory damages to be available.

\section{States with Caps that Exceed the ADA}

\section{Alaska}

Alaska’s damages, as described in AS § 09.17.020(h), exceed those of the ADA for all firm sizes:

"(h) Notwithstanding any other provision of law, in an action against an employer to recover damages for an unlawful employment practice prohibited by AS 18.80.220, the amount of punitive damages awarded by the court or jury may not exceed

(1) $\$ 200,000$ if the employer has less than 100 employees in this state;

(2) $\$ 300,000$ if the employer has 100 or more but less than 200 employees in this state;

(3) $\$ 400,000$ if the employer has 200 or more but less than 500 employees in this state; and

(4) \$500,000 if the employer has 500 or more employees in this state.”

Maine

Maine’s damages, as described in 5 M.R.S.A. §4613(2)(B)(8), exceed those of the ADA for firms with 201 or more employees.

“(e) The sum of compensatory damages awarded under this subparagraph for future pecuniary losses, emotional pain, suffering, inconvenience, mental anguish, loss of enjoyment of life, other nonpecuniary losses and the amount of punitive damages awarded under this section may not exceed for each complaining party:

(i) In the case of a respondent who has more than 14 and fewer than 101 employees in each of 20 or more calendar weeks in the current or preceding calendar year, $\$ 50,000$;

(ii) In the case of a respondent who has more than 100 and fewer than 201 employees in each of 20 or more calendar weeks in the current or preceding calendar year, $\$ 100,000$;

(iii) In the case of a respondent who has more than 200 and fewer than 501 employees in each of 20 or more calendar weeks in the current or preceding calendar year, \$300,000; and

(iv) In the case of a respondent who has more than 500 employees in each of 20 or more calendar weeks in the current or preceding calendar year, $\$ 500,000$.”

Nevada

The section of the statute detailing employment non-discrimination law does not discuss damages, but the statute describing damages in general does apply (NV ST 42.001).

“...Except as otherwise provided in this section or by specific statute, an award of exemplary or punitive damages made pursuant to this section may not exceed:

(a) Three times the amount of compensatory damages awarded to the plaintiff if the amount of compensatory damages is $\$ 100,000$ or more; or

(b) Three hundred thousand dollars if the amount of compensatory damages awarded to the plaintiff is less than $\$ 100,000$.”

Compensatory damages are allowed and uncapped (Green 1992; Buckley and Green 1997, 2002, 2006, 2008, 2009, and 2011) while punitive damages are capped as described above, such that, regardless of 
firm size, punitive damages strictly exceed the sum of both punitive and compensatory damages available under the ADA.

\section{North Carolina}

Compensatory damages are allowed and uncapped (Perry, 2011), while punitive damages are capped pursuant to NC ST § 1D-25:

“§ 1D-25. Limitation of amount of recovery.

(a) In all actions seeking an award of punitive damages, the trier of fact shall determine the amount of punitive damages separately from the amount of compensation for all other damages.

(b) Punitive damages awarded against a defendant shall not exceed three times the amount of compensatory damages or two hundred fifty thousand dollars $(\$ 250,000)$, whichever is greater. If a trier of fact returns a verdict for punitive damages in excess of the maximum amount specified under this subsection, the trial court shall reduce the award and enter judgment for punitive damages in the maximum amount."

Theses damages exceed those under the ADA except in the extremely rare case where firm size is greater than 500 but compensatory damages are less than $\$ 50,000$. In this case the ADA would allow slightly more punitive damages.

\section{States with the Same Damage Caps as the ADA}

\section{Arkansas}

The Arkansas Civil Rights Act (Ark. Code Ann. §§16-123-101 et seq.) specifies the same damage caps as the ADA (§§16-123-107(c)(2)(A)). However, since firms of size nine to 14 are also covered under this law, the damage cap for this group is set at $\$ 15,000$.

\section{Colorado}

The Colorado Anti-Discrimination Act (C.R.S. §§24-34-301 et seq.) allows both compensatory and punitive damages, but explicitly mentions that they are capped at ADA levels (see 42 U.S.C. sec. $1981 \mathrm{a}(\mathrm{b})(3)$ ). Since the firm size minimum is one, damage caps are $\$ 10,000$ for one to four employees, and $\$ 25,000$ for five to 14 employees (C.R.S. §§24-34-405(d)).

\section{Delaware}

The Delaware Discrimination in Employment Act (19 Del. C. $§ 711$ et seq.) specifies that damages are capped at the same level as Title VII of the Civil Rights Act of 1964, which are the same damage caps that apply to the ADA.

\section{Maryland}

The Maryland Fair Employment Practices Act (Md. Code Ann., State Gov’t §20-601 et seq.) provides for the same damage caps as the ADA (Md. Code Ann., State Gov’t §20-1009(3)). Prior to the passage of Acts 2007, c. 176, however, the Maryland Fair Employment Practices Act did not allow punitive damages.

\section{South Carolina}

The South Carolina Human Affairs Law (S.C. Code $\S \S 1-13-10$ et seq.) does not explicitly mention compensatory or punitive damages. DRI (2011, p. 363) argues that the damages are identical to those under Title VII / ADA cases, noting case law which states: "Thus, Title VII cases which interpret provisions or procedures essentially identical to those of the Human Affairs Law are certainly persuasive if not controlling in construing the Human Affairs Laws” (Orr v. Clyburn, 290 S.E.2d 804 (S.C. 1982)). 
The Texas Commission on Human Rights Act (Tex. Lab. Code §§21.001 et seq.) lists the same damage caps as the ADA.

States with Lower Damage Caps than the ADA

\section{Florida}

The Florida Civil Rights Act of 1992 (Fla. Stat. §§760.01 et seq.) allows uncapped compensatory damages, but it caps punitive damages at $\$ 100,000$ (Fla. Stat. $§ \S 760.11(5)$ ).

Idaho

Idaho allows "actual damages,” and the statute does not mention caps, or a lack thereof (Idaho Code §675908(c)). Secondary sources were uninformative as to if this meant that actual damages were uncapped (DRI, 2011, p. 105; Green 1992; Buckley and Green 1997, 2002, 2006, 2008, 2009, and 2011). However, punitive damages are capped at \$1,000 per willful violation (Idaho Code §67-5908(e)).

\section{Kansas}

The Kansas Act Against Discrimination (K.S.A. §44-1001, et seq.) caps damages at \$2,000. DRI (2011, p. 139), citing Labra v. Mid-Plains Constr., Inc., 32 Kan. App. 2d 821, 823, 90 P.3d 954 (2004), notes that it is unclear if this cap applies only to administrative proceedings or if it also applies to private actions.

\section{Minnesota}

The Minnesota Human Rights Act (Minn. Stat. §363A) allows for compensatory damages capped at three times actual damages and punitive damages capped at \$25,000 (Minn. Stat. §363A.29 Subd.4(a)).

\section{States that Do Not Allow Punitive Damages}

\section{Arizona}

Arizona's employment non-discrimination law does not mention compensatory or punitive damages, only mentioning non-monetary remedies, back pay, and that there is available " ... any other equitable relief as the court deems appropriate” (A.R.S. §41-1481(G)). The history preamble to H.B. 2319 (Ariz. 45 ${ }^{\text {th }}$ legislature, 2001), an unpassed bill that attempted to amend this law, states that "Under Arizona law, the Attorney General's Civil Rights Division may only seek relief on behalf of a victim of discrimination in the name of the aggrieved party. Compensatory and punitive damages are not currently available to an aggrieved party under Arizona employment law, although under Arizona's housing law an aggrieved party may be awarded compensatory and punitive damages, and under the Arizonans with Disabilities Act, compensatory damages.”

\section{Connecticut}

Punitive damages are capped as the amount equal to reasonable attorney's fees and costs (DRI, 2011, p. 49) as in Ford v. Blue Cross \& Blue Shield of Conn., Inc., 216 Conn. 40 (1990).

\section{Georgia}

O.C.G.A. §45-19-38(d) states that “Any monetary award ordered pursuant to this article shall be for actual damages only.” This rules out punitive damages (DRI, 2011, p. 88).

Iowa

Case law indicates that punitive damages are not allowed under Iowa's employment non-discrimination law, but compensatory damages are allowed an uncapped. Case law notes via WestLaw (2013a, p. 156) for IA ST § 216.6 states: "Whereas Title VII places cap on compensatory and punitive damages recoverable by plaintiff who prevails on sex discrimination claims, the Iowa Civil Rights Act (ICRA) allows no punitive damages, but does not place cap on amount of compensatory damages. Baker v. John Morrell \& Co., N.D.Iowa2003, 266 F.Supp.2d 909, affirmed 382 F.3d 816, rehearing and rehearing en 
banc denied." Other case law supports a lack of punitive damages: City of Hampton v Iowa Civil Rights Comm'n, 554 N.W.2d (referenced by DRI, 2011, p. 131), Ewing v. Federal Home Loan Bank of Des Moines, S.D.Iowa2009, 645 F.Supp.2d 707, Pospisil v. O'Reilly Automotive, Inc., N.D.Iowa2007, 619 F.Supp.2d 614, and Faust v. Command Center, Inc., S.D.Iowa2007, 484 F.Supp.2d 953, 100 Fair Empl.Prac.Cas. (BNA) 1238. Civil Rights (all three also mentioned in Westlaw, 2013a).

\section{Illinois}

Both Geslewitz (2007) and Smith, O’Callaghan, and White (2007) state that in the Illinois Human Rights Act (775 ILCS 5/1-101 et seq.), punitive damages are not allowed but uncapped compensatory damages are available. Although this law was amended in 2007 to allow a private right of action, this did not change the available remedies.

\section{Indiana}

The Indiana Civil Rights Law does not mention compensatory or punitive damages. Case law clarified that the Indiana Civil Rights Commission (ICRC) is authorized to award damages to compensate for both economic and emotional distress losses but is not authorized to award punitive damages. See Indiana Civil Rights Com'n v. Alder, 1999, 714 N.E.2d 632 (referenced by Westlaw, 2013b, p. 39 and p. 67).

\section{Kentucky}

Kentucky allows for compensatory damages (K.R.S. §344.230 (3); K.R.S. §344.450). No caps are mentioned in statute and other sources do not mention caps except to confirm that caps are not codified in statute (DRI 2011, p. 153; Buckley and Green 1997, 2002, 2006, 2008, 2009, and 2011; Green 1992). The availability of punitive damages was unclear until the Kentucky Supreme Court investigated this in 2003 and 2004. DRI (2011, p. 154) notes that: "The Kentucky Supreme Court recently clarified, in contrast to earlier decisions, that punitive damages are not available under the KCRA statutes. Kentucky Dep’t of Corrs. v. McCullough, 123 S.W.3d 130, 138-39 (Ky. 2003); Brooks v. Lexington-Fayette Urban County Hous. Auth., 132 S.W.3d 790 (Ky. 2004).”

\section{Louisiana}

Louisiana allows compensatory damages, and the statute mentions no caps (La. R.S. §23:303(A)). DRI (2011, p. 160) states that there are no caps. Punitive damages are not available, as DRI (2011, p. 160) notes that “... punitive damages are not available under Louisiana law unless expressly authorized by statute. See, e.g., Ross v. Conoco, Inc., 2002-0299 (La. 10/15/02); 828 So. 2d 546, 555.”

\section{Michigan}

The Michigan’s Persons with Disabilities Civil Rights Act (M.CL. §§37.1101 et seq.) is not explicit about compensatory and punitive damages, stating that: “... 'damages' means damages for injury or loss caused by each violation of this act, including reasonable attorneys’ fees.” (M.CL. §§37.1606(3)) DRI (2011, p. 201) states that while compensatory damages are allowed and uncapped, punitive damages (exemplary damages) are not allowed.

\section{Montana}

The Montana Human Rights Act does not explicitly mention compensatory damages. DRI (2011, p. 229) and Perry (2011) both state that compensatory damages are allowed and uncapped. However, punitive damages are not allowed for employment discrimination and this is noted explicitly in statute (Mont. Code Ann. §§49-2-506(2)).

\section{Nebraska}

The Nebraska Fair Employment Practice Act (Neb. Rev. Stat. §§48-1101 et seq.) does not explicitly indicate if compensatory or punitive damages are available. Gradwohl (1995) and DRI (2011, p. 235) state that punitive damages are generally unavailable in Nebraska. Buckley and Green $(2002,2008)$ state that compensatory damages are available, but do not mention caps or a lack thereof. 


\section{New Hampshire}

According to New Hampshire's employment non-discrimination law, compensatory damages are available (N.H. R.S.A. 354A-21(d)). Punitive damages are not mentioned, but DRI (2011, p. 247) states that New Hampshire law does not allow them.

\section{New Mexico}

The New Mexico Human Rights Act provides for “actual damages” with no caps mentioned (NMSA $\S \S 28-1-11-E)$. DRI (2011, p. 265) indicates that this mean that there are uncapped compensatory damages. ${ }^{27}$ Punitive damages, however, are not available: "The NMHRA provides that an employee may recover actual damages and reasonable attorneys’ fees. NMSA 1978, §§28-1-11(E), 28-1-13(D). This has been interpreted to be confined to compensatory damages. See Trujillo, 2001-NMSC-004, \$30 (“[T]he Human Rights Act does not permit the award of punitive damages.”); Gandy v. Wal-Mart Stores, Inc., 117 N.M. 441, 443, 872 P.2d 859, 861 (1994) ("Punitive damages... are not recoverable under the Human Rights Act.”)” (DRI, 2011, p. 266).

New York

According to the New York law (N.Y. Executive Law §297(4)(c)) “(iii) awarding of compensatory damages to the person aggrieved by such practice; (iv) awarding of punitive damages, in cases of housing discrimination only...” However, according to DRI (2011, p. 274), the compensatory damages that are available are uncapped, and there are civil fines available that mirror capped punitive damages: "As of July 6, 2009, the HRL was amended to provide for the assessment of civil fines and penalties against any employer found to have engaged in an unlawful discriminatory practice. The fines may be imposed in an amount up to $\$ 50,000$, or up to $\$ 100,000$ where the conduct is found to be willful, wanton or malicious” (DRI, 2011, p. 274).

\section{North Dakota}

"Neither the department nor an administrative hearing officer may order compensatory or punitive damages under this chapter” (N.D. Cent. Code §14-02.4-20).

\section{Oklahoma}

Unlike for other protected classes in Oklahoma, aggrieved employees with claims of disability discrimination were previously able to pursue a private action and receive compensatory damages (DRI, 2011, p. 317). However, this was removed effective November 1, 2011, when an amendment (Laws 2011, c. 270, § 21) repealed Okla. Stat. tit. 25, §§1901. It appears that punitive damages were never available, as neither statute nor DRI (2011, p. 317) mention them as having been available.

\section{Pennsylvania}

According to the Pennsylvania Human Relations Act (43 P.S. §§ 951-63), compensatory damages are available but there is no mention of punitive damages. DRI (2011, p. 340) argues that they are not available, citing Hoy v. Angelone, 554, Pa. 134, 720 A.2d 745 (1998), which stated: "[i]n sum, we are of the view that the Legislature's silence on the issue of punitive damages, together with the statutory language, interpreted consistent with the laws of statutory construction and in the context of the nature and purpose of the Act, requires the conclusion that the Legislature did not intend to permit the award of exemplary damages.”

\section{South Dakota}

According to South Dakota's discrimination law, compensatory damages are available, but punitive damages are not available. More specifically, the statute states that “...In a civil action, if the court or jury finds that an unfair or discriminatory practice has occurred, it may award the charging party compensatory damages. The court may grant as relief any injunctive order, including affirmative action,

\footnotetext{
${ }^{27}$ Also see http://www.lawatbdb.com/employee-rights/file_NM?agree=yes (viewed February 2, 2015).
} 
to effectuate the purpose of this chapter. Punitive damages may be awarded under $\S 21-3-2$ for a violation of §§ 20-13-20 to 20-13-21.2, inclusive, 20-13-23.4, or 20-13-23.7” (SDCL §20-13-35.1). However, the listed sections where punitive damages are allowed do not apply to employment discrimination based on disability.

\section{Tennessee}

According to case law notes from Westlaw (2013c, p. 18), under both the Tennessee Human Rights Act (THRA) and Tennessee Handicap Act (THA), compensatory damages are allowed. DRI (2011, p. 379) argues that punitive damages are not available, citing Carver v. Citizen Utils. Co., 954 S.W.2d 34 (Tenn. 1997). See also Forbes v. Wilson County Emergency Dist. 911 Bd., 1998, 966 S.W.2d 417, as cited by Westlaw (2013c, p. 18).

\section{Utah}

The Utah Anti-Discrimination Act states that the following relief is available for those successful in an employment discrimination claim:

“(b) provide relief to the complaining party, including:

(i) reinstatement;

(ii) back pay and benefits;

(iii) attorneys' fees; and

(iv) costs” (U.C.A. §34A-5-107(9)(b)).

Neither compensatory nor punitive damages are mentioned. According to DRI (2011, p. 391), Utah does not allow compensatory or punitive damages.

\section{Virginia}

According to Virginians with Disabilities Act: “Any circuit court having jurisdiction and venue pursuant to Title 8.01, on the petition of any person with a disability, shall have the right to enjoin the abridgement of rights set forth in this chapter and to order such affirmative equitable relief as is appropriate and to award compensatory damages and to award to a prevailing party reasonable attorneys' fees, except that a defendant shall not be entitled to an award of attorneys' fees unless the court finds that the claim was frivolous, unreasonable or groundless, or brought in bad faith. Compensatory damages shall not include damages for pain and suffering. Punitive or exemplary damages shall not be awarded” (Va. Code §51.546(A).).Washington

Washington's employment non-discrimination law (R.C.W. §49.60.030) states that “actual damages” are available, which has been interpreted to be uncapped compensatory damages (DRI, 2011, p. 491; online source). DRI (2011, p. 491) states that punitive damages are not allowed. ${ }^{28}$

\section{Wisconsin}

For most of its history, the Wisconsin Fair Employment Act allowed neither compensatory nor punitive damages. For a brief period between the passage of 2009 Act 20 (effective June 8, 2009) and the passage of 2011 Act 219 (effective April 20, 2012), the Wisconsin Fair Employment Act allowed the same damages as the ADA.

\section{Wyoming}

The Wyoming Fair Employment Practices Act (Wyo. Stat. 27-9-101 et seq.) does not mention compensatory or punitive damages, or a lack thereof. DRI (2011, p. 449) seems to suggest that these damages are not available.

\footnotetext{
${ }^{28}$ See also http://www.workplacefairness.org/file_WA (viewed February 3, 2014).
} 
States with No Law

Alabama

Alabama only has an employment non-discrimination law that protects older workers, but not any other groups.

Mississippi

Mississippi does not have an employment non-discrimination law.

A Brief Note on Age Discrimination Laws

As Table 1 in the paper shows, firm-size minimums are similar for disability and age discrimination laws, but there are 12 states that have a different minimum (AL, AR, DE, GA, KY, IL, IN, LA, NE, OR, SD, VA). With regard to damages, we focus on whether compensatory or punitive damages are allowed, which they are not under federal age discrimination law (the ADEA). Some states require proof of intent to discriminate in order for compensatory or punitive damages to be awarded, whereas others require "willful" violation. Because the federal law allows additional liquidated, non-punitive damages (double back pay and benefits) when there is "willful" violation, the question of whether the state requires intent or willful violation may seem to be potentially relevant in deciding whether a state law offers greater protection. However, willful violation is a much stricter standard than intent (Moberly, 1994). Moreover, compensatory or punitive damages are almost certainly greater than liquidated damages, and they can be much greater. As a consequence, a state law that provides compensatory or punitive damages, whether or not this requires proof of intent or willful violation, clearly entails stronger remedies than the federal law, so our classification captures whether either is allowed. For more details see Neumark and Song (2013). 


\section{References}

Beegle, Kathleen, and Wendy A. Stock. 2003. "The Labor Market Effects of Disability Discrimination Laws.” Journal of Human Resources, Vol. 38, pp. 806-59.

Buckley, John, and Ronald Green. 2011. State by State Guide to Human Resources Law. Aspen Publishers: New York.

Buckley, John, and Ronald Green. 2009. State by State Guide to Human Resources Law. Aspen Publishers: New York

Buckley, John, and Ronald Green. 2008. State by State Guide to Human Resources Law. Aspen Publishers: New York.

Buckley, John, and Ronald Green. 2006. State by State Guide to Human Resources Law. Aspen Publishers: New York.

Buckley, John, and Ronald Green. 2002. State by State Guide to Human Resources Law. Aspen Publishers: New York.

Buckley, John, and Ronald Green. 1997. State by State Guide to Human Resources Law. Aspen Publishers: New York.

Burgdorf, Robert L. 1997. "Substantially Limited: Protection from Disability Discrimination: the Special Treatment Model and Misconstruction of the Definition of Disability.” Villanova Law Review, Vol. 42, pp. 409-586

Button, Patrick. 2015. "Expanding Disability Discrimination Protections to Those with Less Severe Impairments: Evidence from California’s Prudence Kay Poppink Act” Mimeo

Colker, Ruth and Adam Milani (2002) "The Post-Garrett World: Insufficient State Protection Against Disability Discrimination” Alabama Law Review, Vol. 53, pp. 1075-166.

DRI. 2011. Employment and Labor Law State by State Compendium. DRI: Chicago.

Gradwohl, John M. 1995. "Current Dimensions of the Federal Arbitration Act in Nebraska.” Nebraska Law Review, Vol. 74, pp. 304-23.

Green, Ronald. 1992. State by State Guide to Human Resources Law. Panel Publishers.

Long, Alex. 2004. "State Anti-Discrimination Law as a Model for Amending the Americans with Disabilities Act.” University of Pittsburgh Law Review, Vol. 65, pp. 597-653.

Moberly, Michael D. 1994. "Reconsidering the Discriminatory Motive Requirement in ADEA Disparate Treatment Cases.” New Mexico Law Review, Vol. 24, pp. 89-124.

Neumark, David, and Joanne Song. 2013. "Do Stronger Age Discrimination Laws Make Social Security Reforms More Effective?” Journal of Public Economics, Vol. 108, pp. 1-16.

Perry, John. 2011. Equal Employment of Persons with Disabilities. American Bar Association Publishing: Washington.

Westlaw. 2013a. “IA ST § 216.6” Retrieved from Westlaw Campus on July 26, 2013.

Westlaw. 2013b. “IN ST 22-9-1-3” Retrieved from Westlaw Campus on July 26, 2013.

Westlaw. 2013c. “TN ST § 8-50-103” Retrieved from Westlaw Campus on July 31, 2013 
Does Protecting Older Workers from Discrimination Make It Harder to Get Hired? Evidence from Disability Discrimination Laws:

Additional Results Appendix 


\section{Hiring Rates and Self-Reported Labor Force Status}

We do not use reported labor force status or retirement to classify those at risk or not at risk of being hired. There is a well-established set of research findings showing that there are frequent transitions back to employment for those who might classify themselves as retired in a given period (Gustman, 1984; Ruhm, 1990; Blau, 1994; Rust, 1997; and Maestas, 2010), and hence we did not want to classify those who report themselves as retired as not being "as risk" for being hired. This is especially true for the retirement question in the SIPP, which asks if one "ever retired" (in some sense emphasizing the point that "retirement" is not an absorbing state).

We have added a table to the "results on request” file showing hiring rates depending on the different labor force statuses reported by those not employed. (We would have added this to the main paper, absent the space constraints.) Appendix Table A1 shows that there is indeed a good deal of hiring out of self-reported retirement. For example, in the RAND HRS data (which uses a standard CPS-type "labor force status" classification), the hiring rate out of retirement is 0.09 , vs. 0.125 overall. To be sure, the hiring rate is much higher for, say, the unemployed (0.642). But there are far more retired than unemployed workers, so that for our sample hires out of retirement constitute 54.7 percent of hires, whereas hires out of unemployment are only 25.1 percent of hires. As a similar reflection that selfreported labor force status is not strongly determinative of subsequent hiring, the hiring rate for those who report "out of the labor force” is 0.358.

As Appendix Table A1 also shows, this is similar for the SIPP. The notes to the table explain that labor force status and retirement are reported quite differently for the SIPP. But we see, for example, that the hiring rate is 0.049 for those who say they have never retired, 0.013 for those who say they have ever retired, and 0.034 for those who report that they are out of the labor force. (Recall that hiring rates are much lower in the SIPP because of the higher frequency of the data.) Note that the retirement question in the SIPP is only asked for ages 35 and over or 40 and over depending on the panel. Thus we cannot replicate our key difference-in-differences results for the subsample excluding those who say they ever retired, even if we wanted to do so. 


\section{Comparing All Hiring to Hiring out of Non-Employment}

Appendix Figures A1-A6 report the same kind of information, first for the HRS data and then the SIPP data, although now using all hires instead of just hires out of non-employment. One thing that is immediately apparent is that the age profile of employment measured these two ways is quite different. For example, comparing Figures 2 and A1-A3, we see that, for older individuals, the rate of hiring out of non-employment declines with age where the rate of all hiring is fairly flat. And the hiring rate out of non-employment is much higher than the "all hiring” rate until the oldest ages. Comparing Figures 5 and A4-A6 - which use the SIPP data and hence cover a much larger age range - both hiring rates exhibit a hump shape, but the "all hiring" rate peaks at very young ages and then declines, whereas the rate of hiring out of employment remains quite high through all ages although still declining with age. In this case, the hiring rate out of non-employment is also always higher except at the oldest ages.

The overall differences by age in these two hiring rates imply that for all but the oldest ages, employment is a more persistent state than non-employment, which makes sense. Only at older ages do the two hiring rates converge as, on the one hand, older workers are more likely to be retired and hence if non-employed less likely to become re-employed, and at the same time employed older workers may move through bridge jobs on the way to permanent retirement. Moreover, the pronounced decline in the rate of hiring out of non-employment with age, among older individuals, is consistent with nonemployment becoming a "more absorbing” state as people get older. In contrast, "all hiring” stays much flatter, reflecting two offsetting forces - more retirement, and more job changes for those who keep working.

What do these figures show with regard to disability discrimination laws? For the HRS data, Appendix Figures A1-A3 give no different indications. The most pronounced difference is a lower hiring rate of the disabled in states with a stronger definition of disability, which we saw in Figure 2 as well. This is also reflected in Appendix Table A2, which parallels Table 4 in summarizing the results for the figures, although in this case for all hiring.

For the SIPP, too, things appear quite similar. For the broader definition of disability, it still 
appears that hiring of non-disabled workers is if anything lower at younger ages, although the difference is less marked (compare column (3) in Table 4 and Appendix Table A2). And there is still some indication of more hiring of the disabled at younger ages where damages are larger, although again it is less pronounced (compare column (8) in Table 4 and Appendix Table A2).

\section{Dropping 40-49 Year-Olds from the SIPP Analysis}

These results, reported in Appendix Table A4, are very similar to those in Table 6 of the paper, although because of the difference in the scale of the all hiring rate, the estimated coefficients in Appendix Table A4 are smaller.

\section{Additional Analyses Using the Fair/Bad Health as a Disability Measure}

Appendix Figure A7 reports disability by age in the two data sets using this measure. Note that in Appendix Figure A7 we do not observe the dip after age 65 in self-reported disability in the SIPP that we see using a self-reported work-impairing disability measure (Figure 1 in the paper), which likely reflects the fact that those who have left the workforce would necessarily report a disability as limiting work. In the HRS there is no dip using either question, but there is less flattening out for the fair/bad health measure of disability. Appendix Tables A5-A7 report results of these prior analyses with the alternative disability measure. The estimates are qualitatively similar.

\section{Using a More Persistent Work-Limiting Disability Measure}

Our work-limiting disability definition is based on the time of the survey. A potential concern is that, in the SIPP data, this "persistence” could differ between younger and older workers, more so because the data are at a fairly high frequency. Appendix Figure A8 shows that the profile of disability by age looks quite similar using the definition we use in the paper - based on the current response - and definitions based on greater persistence. Specifically, we looked at those who report a work-limiting disability one month ago as well as both one month and two months ago, and then do the same thing based on waves instead (which are every four months). The figures also do not give any clear indication that the proportional change in disability defined these different ways varies with age. (Note that this is not an issue for the fair/poor health measure, because this question is not asked in every wave.) We have 
also computed our key difference-in-differences estimates using the more persistent definition - based on the lower graph, which is more extreme. As reported in Appendix Table A8, the results are robust. Work-Limiting Disability, Self-Reported Health, and Functional Limitations

We use two definitions of disability - work-limiting disabilities, and reported poor or fair health. Measured disability using these two different sources of information is not identical. However, in the HRS data these two measures have similar relationships with difficulties in activities and instrumental activities, with functional limitations, and with doctor-diagnosed medical problems, as shown in Appendix Table A9. 


\section{References}

Blau, David M. 1994. “Labor Force Dynamics of Older Men.” Econometrica, Vol. 62, pp. 117-56.

Gustman, Alan L. 1984. "Partial Retirement and the Analysis of Retirement Behavior.” Industrial and Labor Relations Review, Vol. 37, pp. 403-15.

Maestas, Nicole. 2010. “Back to Work: Expectations and Realizations of Work after Retirement”. Journal of Human Resources, Vol. 45, pp. 718-48.

Ruhm, Christopher J. 1990. “Bridge Jobs and Partial Retirement.” Journal of Labor Economics, Vol. 8, pp. 482-501.

Rust, John. 1990. "Behavior of Male Workers at the End of the Life Cycle: An Empirical Analysis of States and Controls.” In Issues in the Economics of Aging, ed. David A. Wise, 317-82. Chicago: The University of Chicago Press. 
Appendix Figure A1: HRS Hiring Rates Using Inter-Wave Information, by Definition of Disability under Disability Discrimination Laws, for NonDisabled (Left) and Disabled (Right), All Hiring

Non-disabled

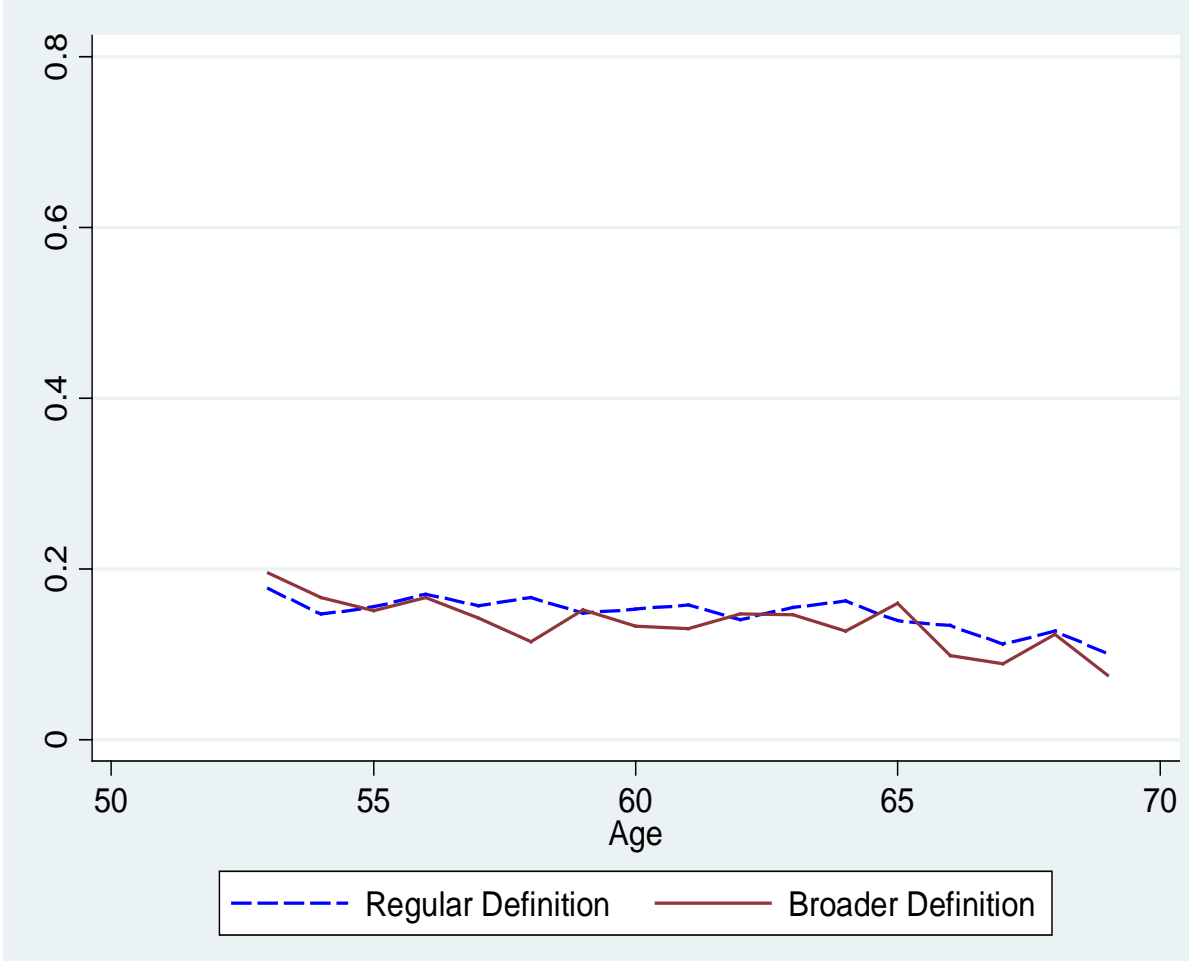

Note: This displays the same information as Figure 2, Panel A, except for all hiring.
Disabled

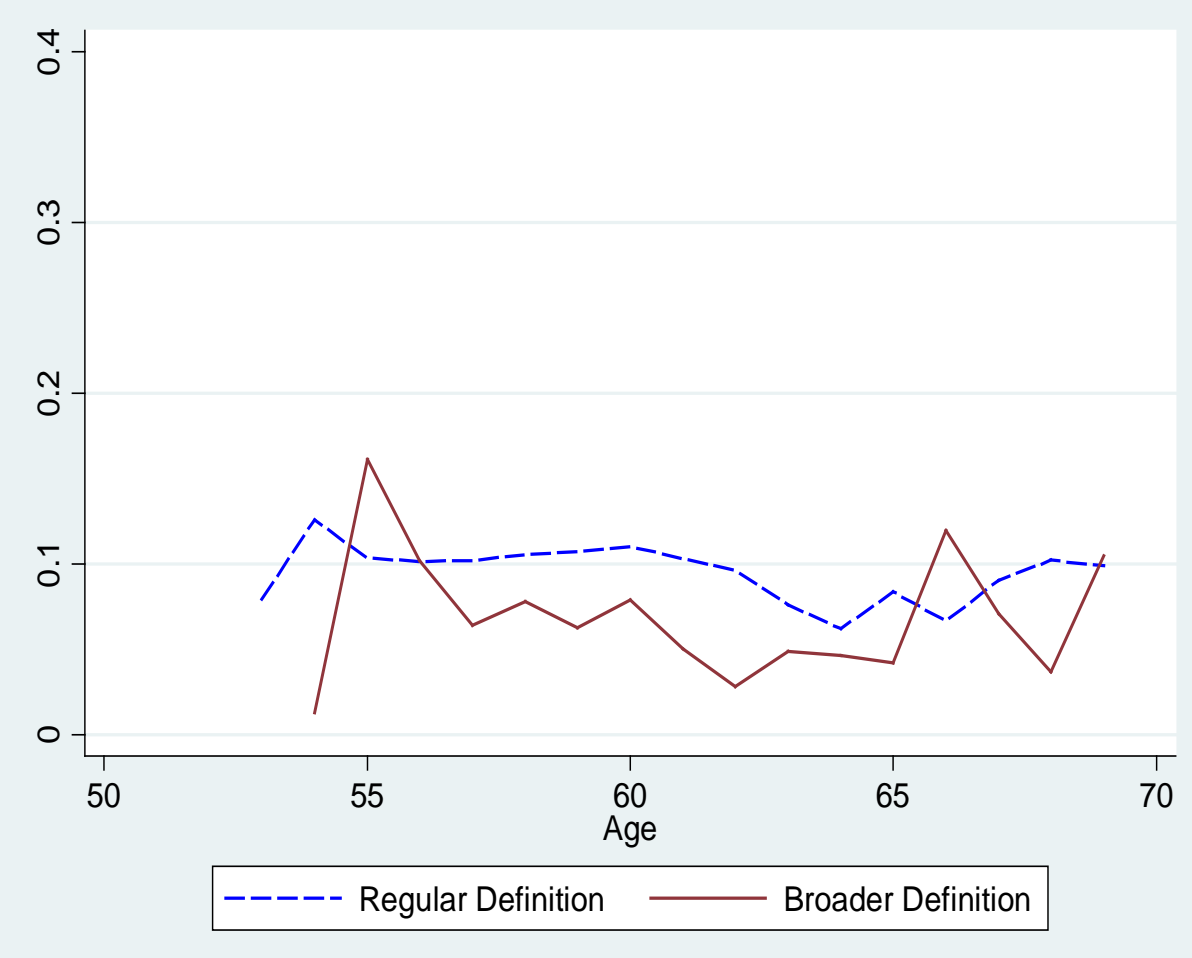


Appendix Figure A2: HRS Hiring Rates Using Inter-Wave Information, by Damages under Disability Discrimination Laws, for Non-Disabled (Left) and Disabled (Right), All Hiring
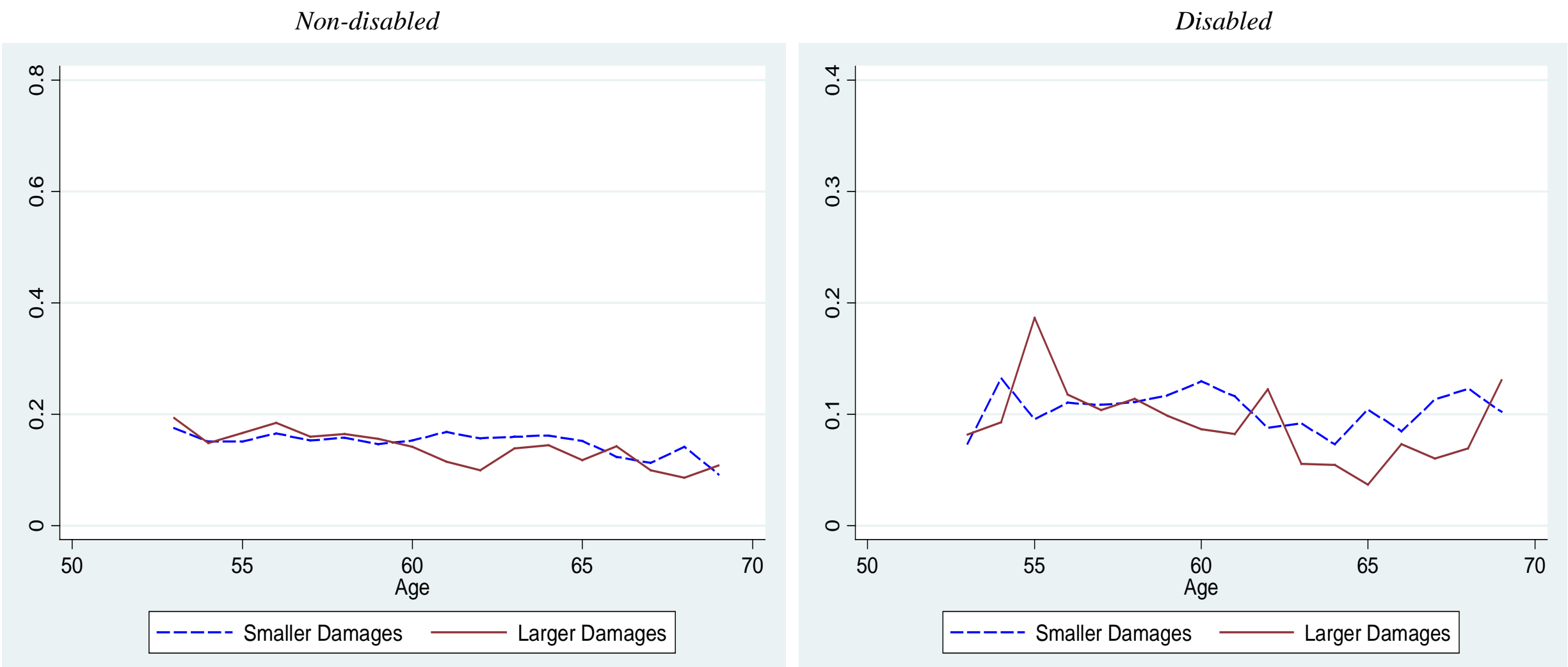

Note: This displays the same information as Figure 2, Panel B, except for all hiring. 
Appendix Figure A3: HRS Hiring Rates Using Inter-Wave Information, by Firm-Size Minimum under Disability Discrimination Laws, for NonDisabled (Left) and Disabled (Right), All Hiring

Non-disabled

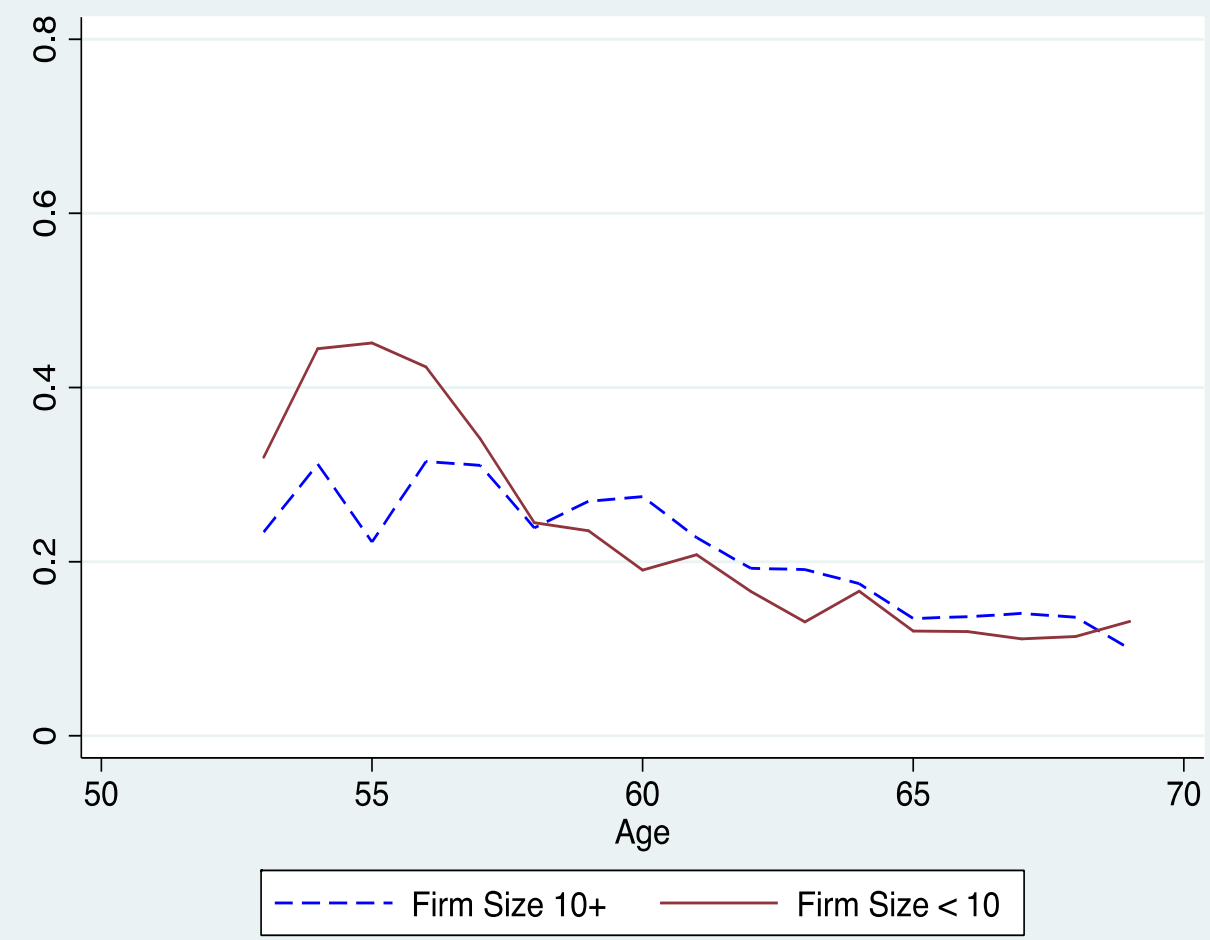

Disabled

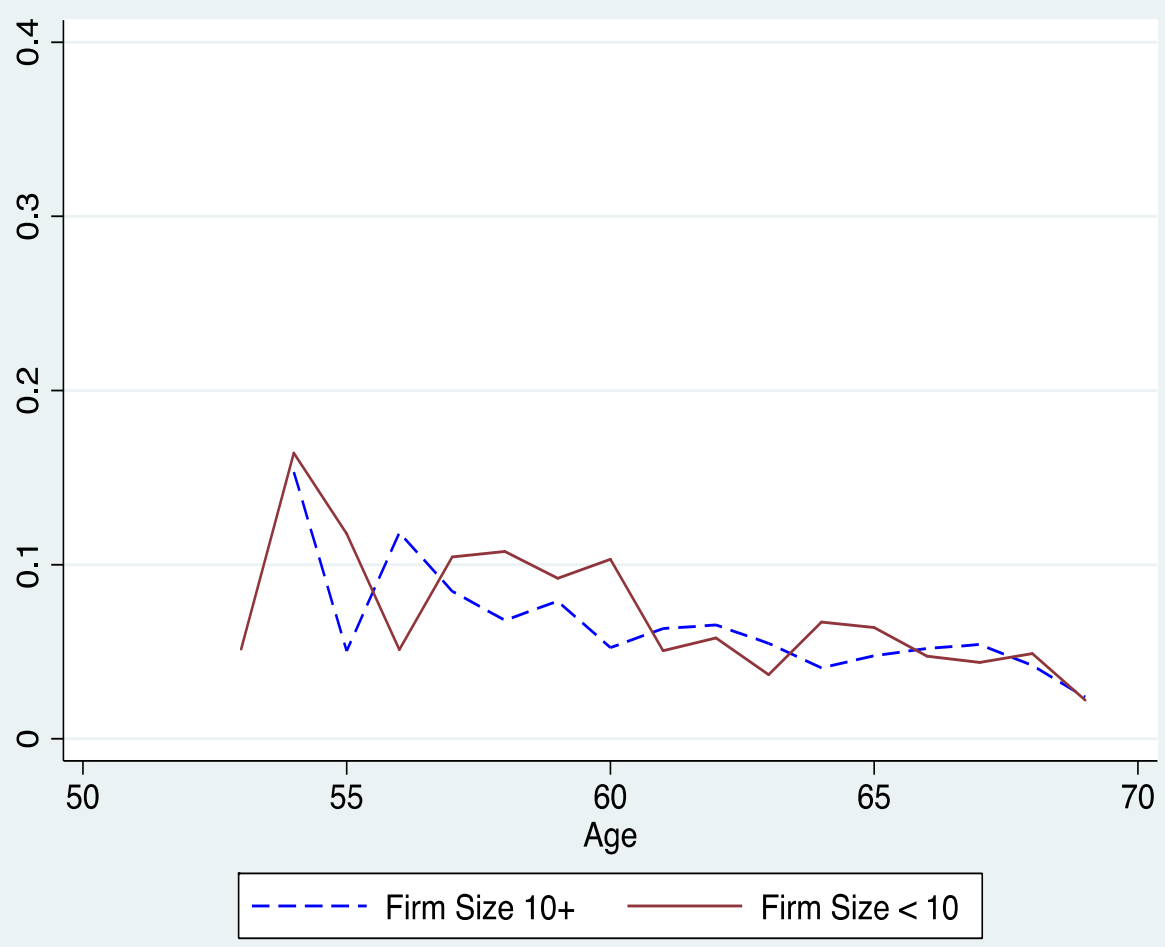

Note: Notes: This displays the same information as Figure 2, Panel C, except for all hiring. 
Appendix Figure A4: SIPP Hiring Rates, by Definition of Disability under Disability Discrimination Laws, for Non-Disabled (Left) and Disabled (Right), All Hiring
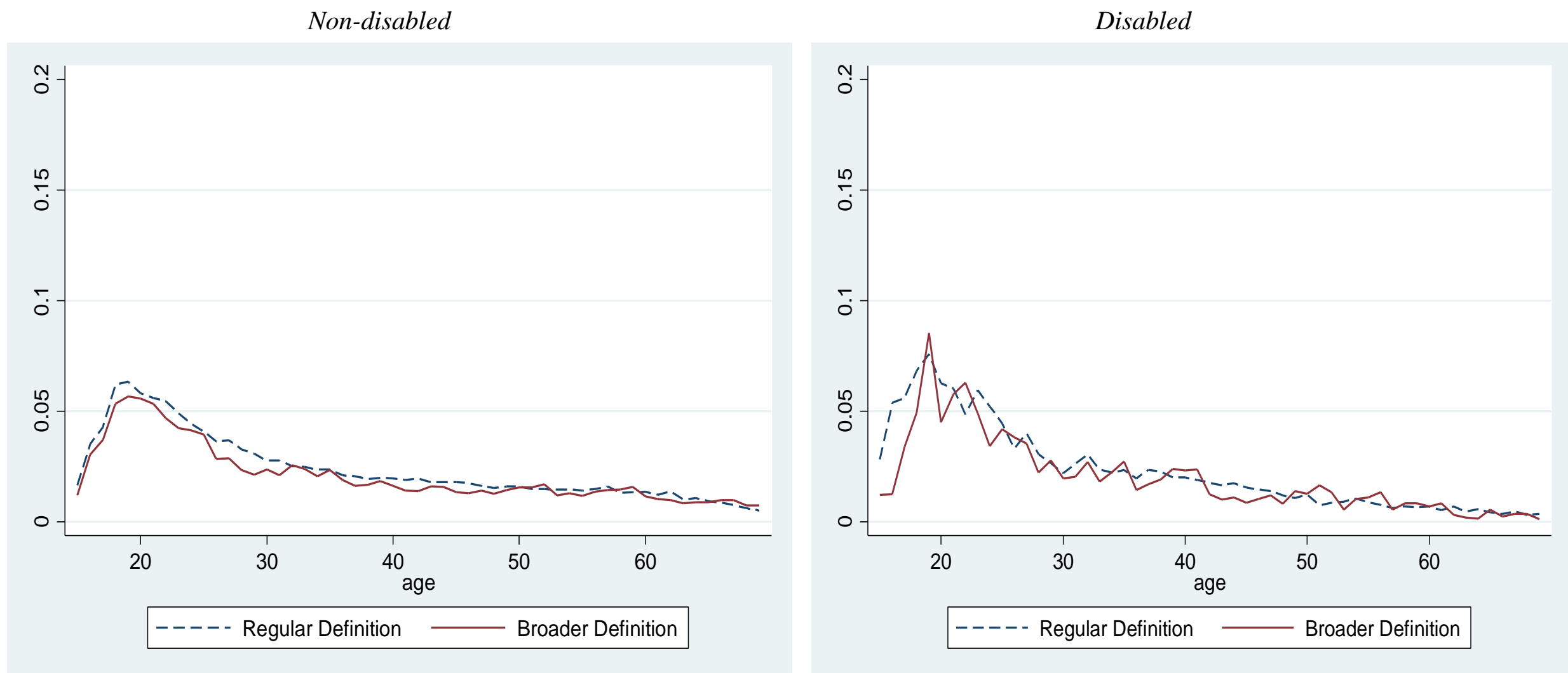

Notes: This displays the same information as Figure 3, Panel A, except for all hiring. 
Appendix Figure A5: SIPP Hiring Rates, by Damages under Disability Discrimination Laws, for Non-Disabled (Left) and Disabled (Right), All Hiring
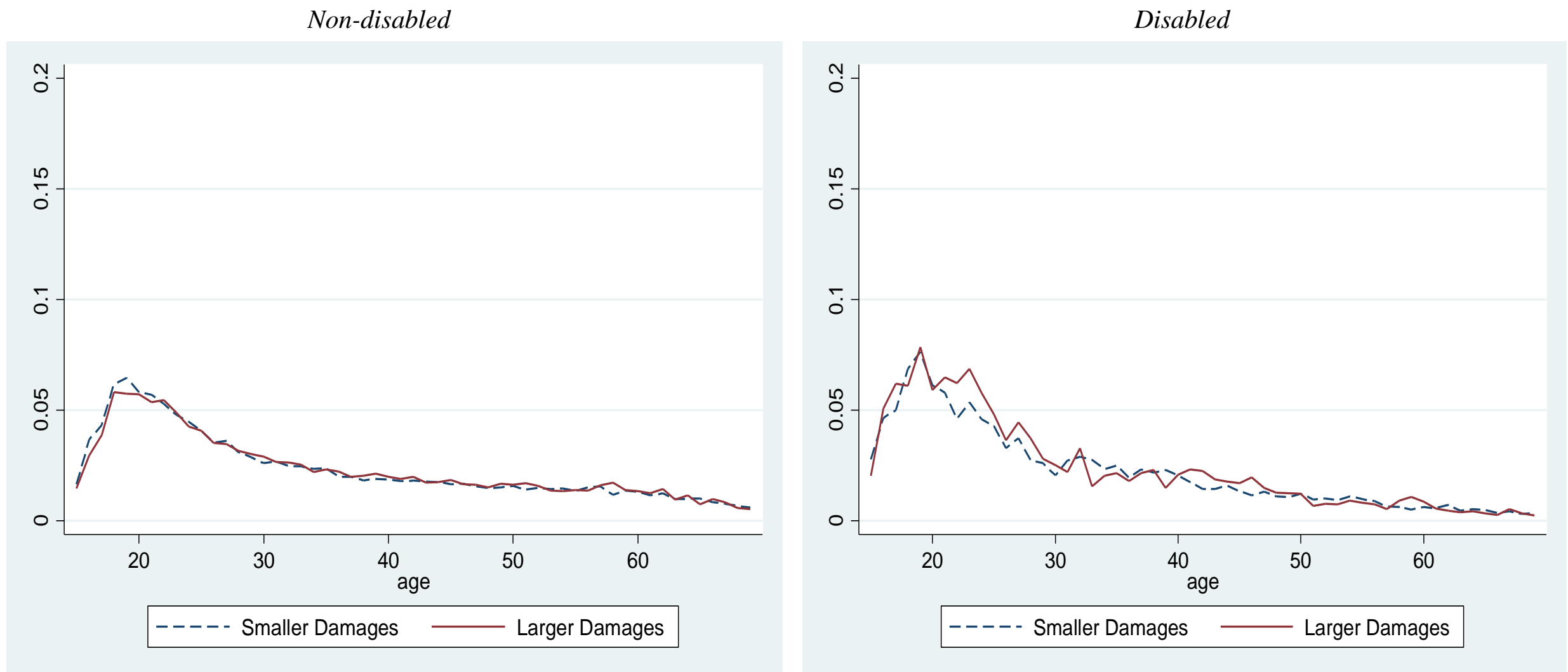

Notes: This displays the same information as Figure 3, Panel B, except for all hiring. 
Appendix Figure A6: SIPP Hiring Rates, by Firm-Size Minimum under Disability Discrimination Laws, for Non-Disabled (Left) and Disabled (Right), All Hiring
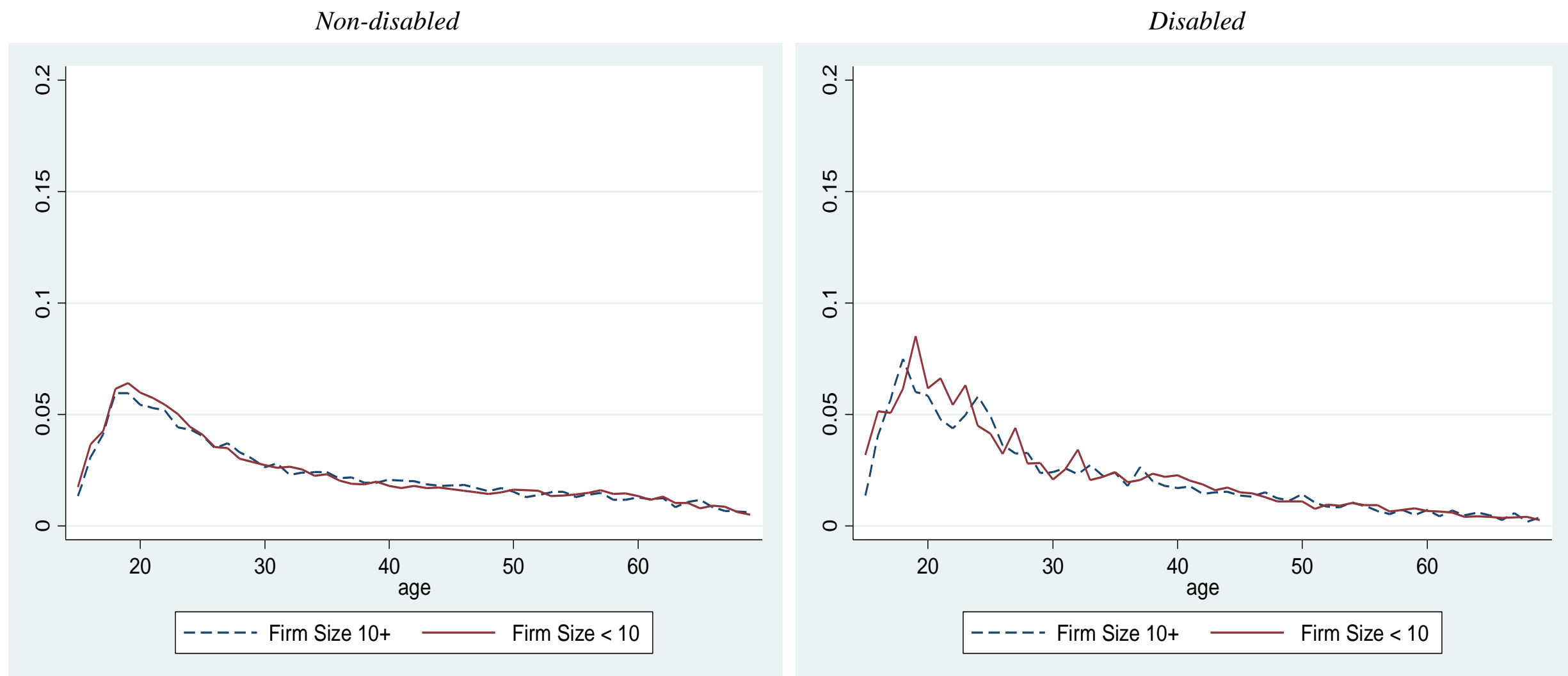

Notes: This displays the same information as Figure 3, Panel C, except for all hiring. 
Appendix Figure A7: Disability by Age in HRS (Left) and SIPP (Right) Data, Substituting Fair or Bad Health as a Disability Measure

HRS

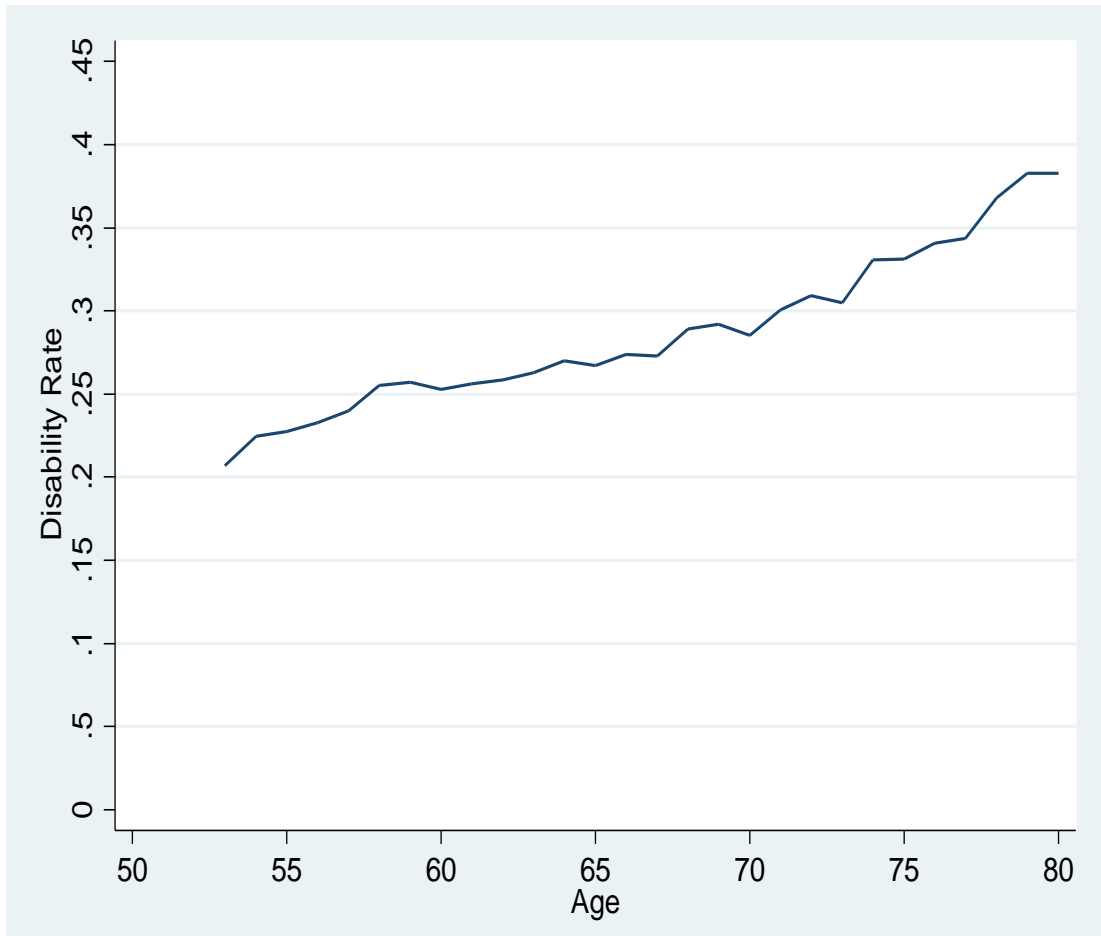

SIPP

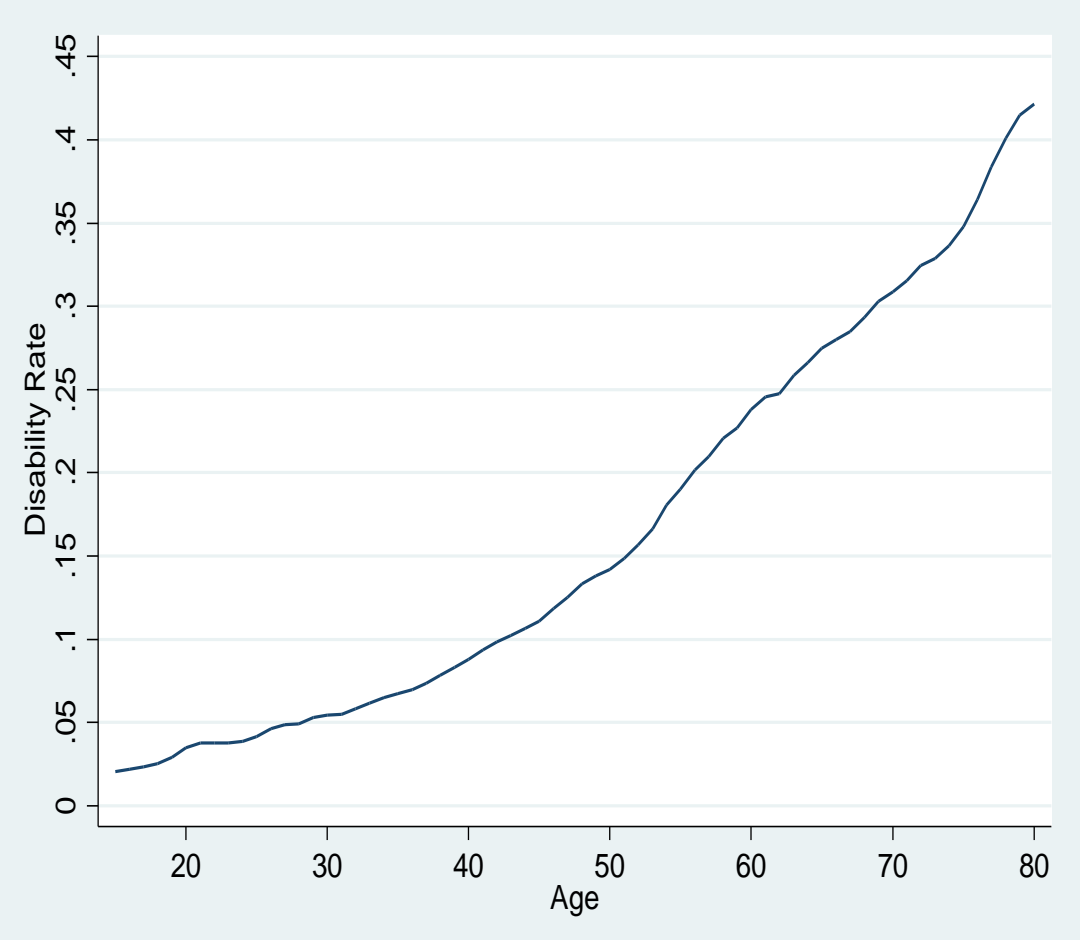

Notes: The disability rates are based on raw data, without adjustment. The disability definition is based on respondent's self-reported general health, which is categorized as excellent, very good, good, fair, or bad. The disability rate is based on respondents who answered fair or bad. 
Appendix Figure A8: Alternative Disability Definitions in SIPP Data Based on Consistent Responses in Previous Periods
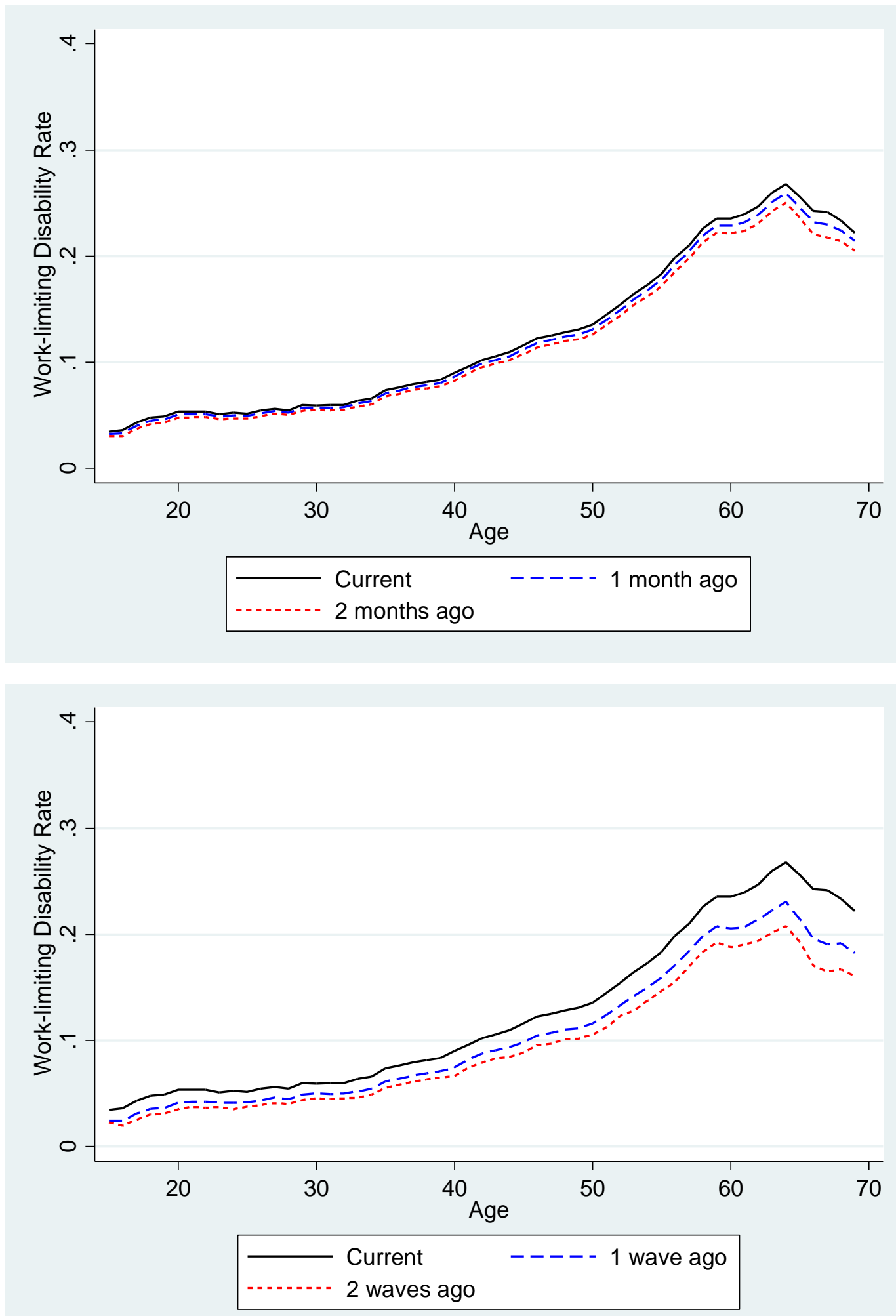

Notes: These figures cannot be produced for the fair/bad health definition of disability because these responses come from less frequent topical modules. 
SIPP

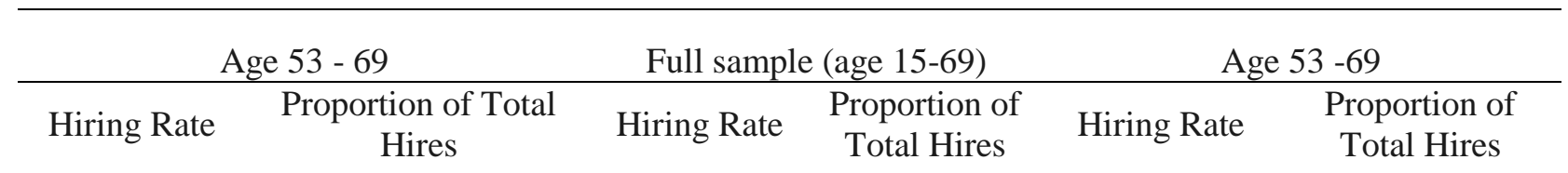

(1)

(2)

(3)

(4)

(6)

Dependent variable:

Hired from non-employment

0.125

(0.004)

$\cdots$

0.053

(0.0003)

..

0.013

(0.0002)

Hiring rate by labor force

status at $t-1$ :

\begin{tabular}{|c|c|c|c|c|c|c|}
\hline Unemployed & $\begin{array}{c}0.642 \\
(0.050)\end{array}$ & $\begin{array}{c}0.251 \\
(0.028)\end{array}$ & $\begin{array}{c}0.151 \\
(0.001)\end{array}$ & $\begin{array}{c}0.463 \\
(0.003)\end{array}$ & $\begin{array}{c}0.139 \\
(0.003)\end{array}$ & $\begin{array}{c}0.338 \\
(0.009)\end{array}$ \\
\hline Partially retired & $\begin{array}{c}0.162 \\
(0.015)\end{array}$ & $\begin{array}{c}0.066 \\
(0.013)\end{array}$ & $\ldots$ & $\ldots$ & $\ldots$ & $\ldots$ \\
\hline Disabled & $\begin{array}{c}0.049 \\
(0.014)\end{array}$ & $\begin{array}{c}0.040 \\
(0.012)\end{array}$ & $\begin{array}{c}0.006 \\
(0.0002)\end{array}$ & $\begin{array}{c}0.076 \\
(0.003)\end{array}$ & $\begin{array}{c}0.003 \\
(0.0003)\end{array}$ & $\begin{array}{c}0.115 \\
(0.011)\end{array}$ \\
\hline Ever retired & & & $\begin{array}{c}0.013 \\
(0.0003)\end{array}$ & $\begin{array}{c}0.287 \\
(0.006)\end{array}$ & $\begin{array}{c}0.011 \\
(0.0003)\end{array}$ & $\begin{array}{c}0.606 \\
(0.011)\end{array}$ \\
\hline Never retired & & & $\begin{array}{c}0.049 \\
(0.001)\end{array}$ & $\begin{array}{c}0.713 \\
(0.006)\end{array}$ & $\begin{array}{c}0.028 \\
(0.001)\end{array}$ & $\begin{array}{c}0.394 \\
(0.011)\end{array}$ \\
\hline $\mathrm{N}$ & \multicolumn{2}{|c|}{10,042} & \multicolumn{2}{|c|}{$1,055,637$} & \multicolumn{2}{|c|}{357,192} \\
\hline
\end{tabular}

Notes: Hiring rates and proportions are calculated pooling the disabled and the non-disabled sample reported in Table 2. This sample excludes hiring out of employment, hence we do not present results for those employed in the previous period. The "disabled" category for labor force status is different from the disability measures we use in the paper (work-limiting, fair or bad health) and captures those who respond not to be in the labor force due to their disability condition. For the SIPP, this question is asked only in the later panels, SIPP 1996, 2001, and 2004. We use the RAND HRS and the above labor force status category is constructed by RAND from various questions related to the employment status. For the SIPP, if respondents report having no job, but looking for work for at least one week, we categorize them as unemployed. If they report having no job and spent no time looking for work, we categorize them as not in labor force. Ever and never retired come from a separate question, "has [respondent] ever retired, for any reason, from a job or business?” This question is asked only for age 40 or older in the SIPP 1992 and 1993, and for age 35 or older in the SIPP 1996, 2001 , and 2004 (so the sample sizes shown in the last row for the SIPP data do not apply to these questions). Thus, we restrict our sample to age 40 or older in calculating hiring rate and proportions of total hired for these two category. Person-level sampling weights are used and standard errors of means are reported in parentheses. 
Appendix Table A2: Estimation Results and Significance Tests for Disability Discrimination Law Provisions, All Hiring

\begin{tabular}{|c|c|c|c|c|c|c|c|c|c|c|c|c|c|}
\hline & & \multicolumn{4}{|c|}{ Broader definition of disability } & \multicolumn{4}{|c|}{ Larger damages } & \multicolumn{4}{|c|}{ Firm-size minimum $<10$} \\
\hline & & \multicolumn{2}{|c|}{$\underline{\mathrm{HRS}}$} & \multicolumn{2}{|c|}{ SIPP } & \multicolumn{2}{|c|}{ HRS } & \multicolumn{2}{|c|}{ SIPP } & \multicolumn{2}{|c|}{ HRS } & \multicolumn{2}{|c|}{$\underline{\text { SIPP }}$} \\
\hline & & $\begin{array}{c}\text { Non- } \\
\text { disabled } \\
(1)\end{array}$ & $\begin{array}{c}\text { Disabled } \\
(2) \\
\end{array}$ & $\begin{array}{c}\text { Non- } \\
\text { disabled } \\
(3)\end{array}$ & $\begin{array}{c}\text { Disabled } \\
(4)\end{array}$ & $\begin{array}{c}\text { Non- } \\
\text { disabled } \\
(5)\end{array}$ & $\begin{array}{c}\text { Disabled } \\
(6)\end{array}$ & $\begin{array}{c}\text { Non- } \\
\text { disabled } \\
(7)\end{array}$ & $\begin{array}{c}\text { Disabled } \\
(8) \\
\end{array}$ & $\begin{array}{c}\text { Non- } \\
\text { disabled } \\
(9)\end{array}$ & $\begin{array}{c}\text { Disabled } \\
(10)\end{array}$ & $\begin{array}{c}\text { Non- } \\
\text { disabled } \\
(11)\end{array}$ & $\begin{array}{c}\text { Disabled } \\
(12) \\
\end{array}$ \\
\hline Age 20-29 & $\begin{array}{l}\text { Avg. diff. } \\
\text { \% pos. } \\
\text { p-value }\end{array}$ & $\ldots$ & $\ldots$ & $\begin{array}{c}-0.006 \\
0 \% \\
0.000\end{array}$ & $\begin{array}{c}-0.004 \\
30 \% \\
0.000\end{array}$ & $\ldots$ & $\ldots$ & $\begin{array}{c}-0.0003 \\
40 \% \\
0.163\end{array}$ & $\begin{array}{c}0.008 \\
90 \% \\
0.949\end{array}$ & $\ldots$ & $\ldots$ & $\begin{array}{c}0.001 \\
70 \% \\
0.003\end{array}$ & $\begin{array}{c}0.003 \\
60 \% \\
0.078\end{array}$ \\
\hline Age 30-39 & $\begin{array}{l}\text { Avg. diff. } \\
\text { \% pos. } \\
\text { p-value }\end{array}$ & $\ldots$ & $\ldots$ & $\begin{array}{c}-0.002 \\
10 \% \\
0.000\end{array}$ & $\begin{array}{c}-0.002 \\
30 \% \\
0.000\end{array}$ & $\ldots$ & $\ldots$ & $\begin{array}{c}0.001 \\
70 \% \\
0.006\end{array}$ & $\begin{array}{c}-0.003 \\
30 \% \\
0.000\end{array}$ & $\ldots$ & $\ldots$ & $\begin{array}{c}-0.0002 \\
40 \% \\
0.013\end{array}$ & $\begin{array}{c}0.0003 \\
50 \% \\
0.042\end{array}$ \\
\hline Age 40-49 & $\begin{array}{l}\text { Avg. diff. } \\
\text { \% pos. } \\
\text { p-value }\end{array}$ & $\ldots$ & $\ldots$ & $\begin{array}{c}-0.003 \\
0 \% \\
0.000\end{array}$ & $\begin{array}{c}-0.002 \\
30 \% \\
0.000\end{array}$ & $\cdots$ & $\ldots$ & $\begin{array}{c}0.001 \\
70 \% \\
0.518\end{array}$ & $\begin{array}{l}0.004 \\
100 \% \\
0.216\end{array}$ & $\ldots$ & $\ldots$ & $\begin{array}{c}-0.002 \\
0 \% \\
0.334\end{array}$ & $\begin{array}{c}0.001 \\
70 \% \\
0.213\end{array}$ \\
\hline Age 50-61 & $\begin{array}{l}\text { Avg. diff. } \\
\text { \% pos. } \\
\text { p-value }\end{array}$ & $\ldots$ & $\ldots$ & $\begin{array}{c}-0.001 \\
33.3 \% \\
0.000\end{array}$ & $\begin{array}{c}0.002 \\
66.7 \% \\
0.000\end{array}$ & $\ldots$ & $\ldots$ & $\begin{array}{c}0.001 \\
75 \% \\
0.0004\end{array}$ & $\begin{array}{c}-0.0003 \\
25 \% \\
0.0004\end{array}$ & $\ldots$ & $\ldots$ & $\begin{array}{c}0.001 \\
75 \% \\
0.218\end{array}$ & $\begin{array}{c}0.0004 \\
58.3 \% \\
0.026\end{array}$ \\
\hline Age 62-69 & $\begin{array}{l}\text { Avg. diff. } \\
\text { \% pos. } \\
\text { p-value }\end{array}$ & $\begin{array}{c}-0.071 \\
25 \% \\
0.809\end{array}$ & $\begin{array}{c}-0.201 \\
25 \% \\
0.453\end{array}$ & $\begin{array}{c}-0.0001 \\
50 \% \\
0.000\end{array}$ & $\begin{array}{l}-0.002 \\
25 \% \\
0.000\end{array}$ & $\begin{array}{c}-0.098 \\
22.2 \% \\
0.052\end{array}$ & $\begin{array}{c}-0.169 \\
22.2 \% \\
0.194\end{array}$ & $\begin{array}{c}0.0001 \\
50 \% \\
0.001\end{array}$ & $\begin{array}{c}-0.001 \\
25 \% \\
0.889\end{array}$ & $\begin{array}{c}-0.064 \\
33.3 \% \\
0.205\end{array}$ & $\begin{array}{c}-0.062 \\
22.2 \% \\
0.099\end{array}$ & $\begin{array}{c}-0.000 \\
50 \% \\
0.004\end{array}$ & $\begin{array}{c}-0.0005 \\
25 \% \\
0.128\end{array}$ \\
\hline Age $40-52$ & $\begin{array}{l}\text { Avg. diff. } \\
\text { \% pos. } \\
\text { p-value }\end{array}$ & $\cdots$ & $\cdots$ & $\begin{array}{c}-0.002 \\
15.4 \% \\
0.000\end{array}$ & $\begin{array}{c}-0.001 \\
46.2 \% \\
0.000\end{array}$ & $\cdots$ & $\ldots$ & $\begin{array}{c}0.001 \\
76.9 \% \\
0.224\end{array}$ & $\begin{array}{c}0.002 \\
76.9 \% \\
0.021\end{array}$ & $\cdots$ & $\ldots$ & $\begin{array}{c}-0.001 \\
23.1 \% \\
0.000\end{array}$ & $\begin{array}{c}0.001 \\
61.5 \% \\
0.108\end{array}$ \\
\hline Age 53-61 & $\begin{array}{l}\text { Avg. diff. } \\
\% \text { pos. } \\
\text { p-value }\end{array}$ & $\begin{array}{c}-0.042 \\
33.3 \% \\
0.873\end{array}$ & $\begin{array}{c}-0.261 \\
25 \% \\
0.221\end{array}$ & $\begin{array}{c}-0.001 \\
22.2 \% \\
0.000\end{array}$ & $\begin{array}{c}0.001 \\
55.6 \% \\
0.000\end{array}$ & $\begin{array}{c}-0.000 \\
75 \% \\
0.757\end{array}$ & $\begin{array}{c}-0.026 \\
50 \% \\
0.831\end{array}$ & $\begin{array}{c}0.0005 \\
66.7 \% \\
0.001\end{array}$ & $\begin{array}{c}0.0003 \\
33.3 \% \\
0.001\end{array}$ & $\begin{array}{c}-0.050 \\
37.5 \% \\
0.253\end{array}$ & $\begin{array}{c}-0.128 \\
37.5 \% \\
0.582\end{array}$ & $\begin{array}{c}0.001 \\
66.7 \% \\
0.692\end{array}$ & $\begin{array}{c}0.001 \\
66.7 \% \\
0.397\end{array}$ \\
\hline Age 53-69 & $\begin{array}{l}\text { Avg. diff. } \\
\% \text { pos. } \\
\text { p-value }\end{array}$ & $\begin{array}{c}-0.056 \\
29.4 \% \\
0.940 \\
\end{array}$ & $\begin{array}{c}-0.231 \\
25 \% \\
0.298 \\
\end{array}$ & $\begin{array}{c}-0.001 \\
35.3 \% \\
0.000 \\
\end{array}$ & $\begin{array}{c}-0.0002 \\
41.2 \% \\
0.000\end{array}$ & $\begin{array}{c}-0.047 \\
47.1 \% \\
0.218 \\
\end{array}$ & $\begin{array}{c}-0.093 \\
35.3 \% \\
0.515 \\
\end{array}$ & $\begin{array}{c}0.0003 \\
58.8 \% \\
0.000 \\
\end{array}$ & $\begin{array}{c}-0.0002 \\
29.4 \% \\
0.000 \\
\end{array}$ & $\begin{array}{c}-0.057 \\
35.3 \% \\
0.183 \\
\end{array}$ & $\begin{array}{c}-0.097 \\
29.4 \% \\
0.233 \\
\end{array}$ & $\begin{array}{c}0.0003 \\
58.8 \% \\
0.001 \\
\end{array}$ & $\begin{array}{c}0.0003 \\
47.1 \% \\
0.033 \\
\end{array}$ \\
\hline
\end{tabular}

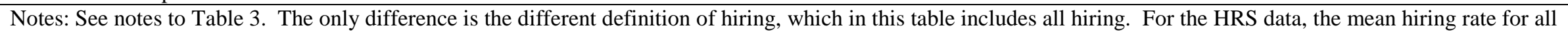

hiring is 0.150 for the non-disabled, and 0.097 for the disabled. For the SIPP data, the corresponding numbers are 0.028 (non-disabled) and 0.018 (disabled). 
Appendix Table A3: Difference-in-Differences Estimates of Effects of Stronger Disability Discrimination Laws on Hiring of Non-Disabled Older Workers, SIPP Data, All Hiring

\begin{tabular}{|c|c|c|c|c|c|c|c|c|}
\hline & (1) & (2) & (3) & (4) & (5) & (6) & (7) & (8) \\
\hline $\begin{array}{l}\text { Age } \geq 50 \times \text { broader } \\
\text { definition of disability }\end{array}$ & $\begin{array}{l}0.002^{* *} \\
(0.001)\end{array}$ & $\ldots$ & $\cdots$ & $\begin{array}{c}0.002 \\
(0.001)\end{array}$ & $\begin{array}{l}0.002^{*} \\
(0.001)\end{array}$ & ... & $\ldots$ & $\begin{array}{c}0.001 \\
(0.001)\end{array}$ \\
\hline $\begin{array}{l}\text { Age } \geq 50 \times \text { larger } \\
\text { damages }\end{array}$ & $\ldots$ & $\begin{array}{l}-0.0002 \\
(0.001)\end{array}$ & $\ldots$ & $\begin{array}{l}-0.001 \\
(0.001)\end{array}$ & $\ldots$ & $\begin{array}{l}-0.001 \\
(0.001)\end{array}$ & $\ldots$ & $\begin{array}{l}-0.001 \\
(0.001)\end{array}$ \\
\hline Age $\geq 50 \times$ firm size $<10$ & $\ldots$ & $\ldots$ & $\begin{array}{l}0.002^{* * *} \\
(0.001)\end{array}$ & $\begin{array}{l}0.002^{* *} \\
(0.001)\end{array}$ & $\ldots$ & $\ldots$ & $\begin{array}{l}0.002^{* * *} \\
(0.001)\end{array}$ & $\begin{array}{c}0.001 \\
(0.001)\end{array}$ \\
\hline $\begin{array}{l}\text { Age } \geq 50 \times \text { age disc. } \\
\text { larger damages }\end{array}$ & $\ldots$ & $\ldots$ & $\cdots$ & $\ldots$ & $\begin{array}{l}0.001^{*} \\
(0.001)\end{array}$ & $\begin{array}{l}0.001^{* *} \\
(0.001)\end{array}$ & $\begin{array}{c}0.001 \\
(0.001)\end{array}$ & $\begin{array}{c}0.001 \\
(0.001)\end{array}$ \\
\hline $\begin{array}{l}\text { Age } \geq 50 \times \text { age disc. firm } \\
\text { size }<10\end{array}$ & $\cdots$ & $\cdots$ & $\ldots$ & $\cdots$ & $\begin{array}{c}0.001 \\
(0.000)\end{array}$ & $\begin{array}{c}0.001 \\
(0.001)\end{array}$ & $\begin{array}{l}-0.001 \\
(0.001)\end{array}$ & $\begin{array}{l}-0.000 \\
(0.001)\end{array}$ \\
\hline $\begin{array}{l}\text { Age } \geq 55 \times \text { broader } \\
\text { definition of disability }\end{array}$ & $\begin{array}{c}0.002^{*} \\
(0.001)\end{array}$ & $\cdots$ & $\ldots$ & $\begin{array}{r}0.001 \\
(0.001)\end{array}$ & $\begin{array}{c}0.001 \\
(0.001)\end{array}$ & $\ldots$ & $\ldots$ & $\begin{array}{c}0.001 \\
(0.001)\end{array}$ \\
\hline $\begin{array}{l}\text { Age } \geq 55 \times \text { larger } \\
\text { damages }\end{array}$ & $\cdots$ & $\begin{array}{l}-0.0002 \\
(0.001)\end{array}$ & $\cdots$ & $\begin{array}{l}-0.001 \\
(0.001)\end{array}$ & $\cdots$ & $\begin{array}{l}-0.001 \\
(0.001)\end{array}$ & $\ldots$ & $\begin{array}{l}-0.001 \\
(0.001)\end{array}$ \\
\hline $\begin{array}{l}\text { Age } \geq 55 \times \text { age disc } \\
\text { larger damages }\end{array}$ & $\ldots$ & $\cdots$ & $\cdots$ & $\ldots$ & $\begin{array}{l}0.0004 \\
(0.001)\end{array}$ & $\begin{array}{c}0.001 \\
(0.001)\end{array}$ & $\begin{array}{l}0.0003 \\
(0.001)\end{array}$ & $\begin{array}{l}0.0004 \\
(0.001)\end{array}$ \\
\hline $\begin{array}{l}\text { Age } \geq 55 \times \text { age disc. firm } \\
\text { size }<10\end{array}$ & $\ldots$ & $\cdots$ & $\cdots$ & $\ldots$ & $\begin{array}{c}0.001 \\
(0.001)\end{array}$ & $\begin{array}{c}0.001 \\
(0.001)\end{array}$ & $\begin{array}{l}-0.0004 \\
(0.001)\end{array}$ & $\begin{array}{l}-0.000 \\
(0.001)\end{array}$ \\
\hline $\begin{array}{l}\text { Age } \geq 60 \times \text { broader } \\
\text { definition of disability }\end{array}$ & $\begin{array}{l}0.001^{*} \\
(0.001)\end{array}$ & $\ldots$ & $\ldots$ & $\begin{array}{c}0.001 \\
(0.001)\end{array}$ & $\begin{array}{c}0.001 \\
(0.001)\end{array}$ & $\ldots$ & $\ldots$ & $\begin{array}{c}0.001 \\
(0.001)\end{array}$ \\
\hline $\begin{array}{l}\text { Age } \geq 60 \times \text { larger } \\
\text { damages }\end{array}$ & $\cdots$ & $\begin{array}{l}-0.001 \\
(0.001)\end{array}$ & $\cdots$ & $\begin{array}{l}-0.001 \\
(0.001)\end{array}$ & $\cdots$ & $\begin{array}{l}-0.001 \\
(0.001)\end{array}$ & ... & $\begin{array}{l}-0.001 \\
(0.001)\end{array}$ \\
\hline Age $\geq 60 \times$ firm size $<10$ & $\cdots$ & $\ldots$ & $\begin{array}{c}0.001 \\
(0.001)\end{array}$ & $\begin{array}{c}0.001 \\
(0.001)\end{array}$ & $\ldots$ & $\ldots$ & $\begin{array}{c}0.001 \\
(0.001)\end{array}$ & $\begin{array}{l}0.0002 \\
(0.001)\end{array}$ \\
\hline $\begin{array}{l}\text { Age } \geq 60 \times \text { age disc } \\
\text { larger damages }\end{array}$ & $\ldots$ & $\ldots$ & $\ldots$ & $\ldots$ & $\begin{array}{c}0.000 \\
(0.001)\end{array}$ & $\begin{array}{l}0.0005 \\
(0.001)\end{array}$ & $\begin{array}{l}0.0002 \\
(0.001)\end{array}$ & $\begin{array}{l}0.0002 \\
(0.001)\end{array}$ \\
\hline $\begin{array}{l}\text { Age } \geq 60 \times \text { age disc. firm } \\
\text { size }<10\end{array}$ & $\ldots$ & $\ldots$ & $\ldots$ & $\cdots$ & $\begin{array}{l}0.0004 \\
(0.001)\end{array}$ & $\begin{array}{c}0.001 \\
(0.001)\end{array}$ & $\begin{array}{l}-0.000 \\
(0.001)\end{array}$ & $\begin{array}{l}0.0004 \\
(0.001)\end{array}$ \\
\hline
\end{tabular}

Notes: See notes to Table 5. The only difference is the different definition of hiring, which in this table includes all hiring. 
Appendix Table A4: Difference-in-Differences Estimates of Effects of Stronger Disability Discrimination Laws on Hiring of Non-Disabled Older Workers, SIPP Data, Excluding Age 40-49 from the Control Group, Hiring from Non-Employment

\begin{tabular}{|c|c|c|c|c|c|c|c|c|}
\hline & (1) & (2) & (3) & (4) & (5) & (6) & (7) & (8) \\
\hline $\begin{array}{l}\text { Age } \geq 50 \times \text { broader } \\
\text { definition of disability }\end{array}$ & $\begin{array}{c}0.012 \\
(0.007)\end{array}$ & $\ldots$ & $\ldots$ & $\begin{array}{c}0.014 \\
(0.009)\end{array}$ & $\begin{array}{l}0.012^{*} \\
(0.007)\end{array}$ & $\ldots$ & $\ldots$ & $\begin{array}{l}0.017^{*} \\
(0.010)\end{array}$ \\
\hline Age $\geq 50 \times$ larger damages & $\ldots$ & $\begin{array}{c}0.006 \\
(0.005)\end{array}$ & $\ldots$ & $\begin{array}{c}0.008 \\
(0.007)\end{array}$ & $\ldots$ & $\begin{array}{c}0.005 \\
(0.006)\end{array}$ & $\ldots$ & $\begin{array}{c}0.009 \\
(0.007)\end{array}$ \\
\hline Age $\geq 50 \times$ firm size $<10$ & $\ldots$ & $\ldots$ & $\begin{array}{c}0.005 \\
(0.006)\end{array}$ & $\begin{array}{l}-0.002 \\
(0.006)\end{array}$ & $\ldots$ & $\ldots$ & $\begin{array}{l}0.0003 \\
(0.007)\end{array}$ & $\begin{array}{l}-0.009 \\
(0.008)\end{array}$ \\
\hline $\begin{array}{l}\text { Age } \geq 50 \times \text { age disc. larger } \\
\text { damages }\end{array}$ & $\cdots$ & $\cdots$ & $\ldots$ & $\ldots$ & $\begin{array}{l}-0.003 \\
(0.006)\end{array}$ & $\begin{array}{l}-0.002 \\
(0.007)\end{array}$ & $\begin{array}{l}-0.001 \\
(0.007)\end{array}$ & $\begin{array}{l}-0.004 \\
(0.008)\end{array}$ \\
\hline $\begin{array}{l}\text { Age } \geq 50 \times \text { age disc. firm } \\
\text { size }<10\end{array}$ & $\cdots$ & $\ldots$ & $\ldots$ & $\ldots$ & $\begin{array}{c}0.007 \\
(0.006)\end{array}$ & $\begin{array}{c}0.006 \\
(0.006)\end{array}$ & $\begin{array}{c}0.007 \\
(0.005)\end{array}$ & $\begin{array}{l}0.011^{*} \\
(0.005)\end{array}$ \\
\hline $\begin{array}{l}\text { Age } \geq 55 \times \text { broader } \\
\text { definition of disability }\end{array}$ & $\begin{array}{c}0.012^{*} \\
(0.007)\end{array}$ & $\cdots$ & $\ldots$ & $\begin{array}{l}0.011^{*} \\
(0.008)\end{array}$ & $\begin{array}{l}0.012^{* *} \\
(0.006)\end{array}$ & $\ldots$ & $\ldots$ & $\begin{array}{l}0.015^{*} \\
(0.008)\end{array}$ \\
\hline Age $\geq 55 \times$ larger damages & $\ldots$ & $\begin{array}{c}0.004 \\
(0.005)\end{array}$ & $\ldots$ & $\begin{array}{c}0.004 \\
(0.005)\end{array}$ & $\ldots$ & $\begin{array}{c}0.002 \\
(0.005)\end{array}$ & $\ldots$ & $\begin{array}{c}0.005 \\
(0.006)\end{array}$ \\
\hline Age $\geq 55 \times$ firm size $<10$ & $\ldots$ & $\ldots$ & $\begin{array}{c}0.007 \\
(0.006)\end{array}$ & $\begin{array}{c}0.003 \\
(0.006)\end{array}$ & $\ldots$ & $\ldots$ & $\begin{array}{c}0.003 \\
(0.005)\end{array}$ & $\begin{array}{l}-0.004 \\
(0.006)\end{array}$ \\
\hline $\begin{array}{l}\text { Age } \geq 55 \times \text { age disc. larger } \\
\text { damages }\end{array}$ & $\ldots$ & $\ldots$ & $\ldots$ & $\ldots$ & $\begin{array}{l}-0.005 \\
(0.005)\end{array}$ & $\begin{array}{l}-0.003 \\
(0.006)\end{array}$ & $\begin{array}{l}-0.003 \\
(0.006)\end{array}$ & $\begin{array}{l}-0.005 \\
(0.006)\end{array}$ \\
\hline $\begin{array}{l}\text { Age } \geq 55 \times \text { age disc. firm } \\
\text { size }<10\end{array}$ & $\cdots$ & .. & $\ldots$ & $\ldots$ & $\begin{array}{c}0.009 \\
(0.005)\end{array}$ & $\begin{array}{c}0.008 \\
(0.006)\end{array}$ & $\begin{array}{c}0.007 \\
(0.004)\end{array}$ & $\begin{array}{l}0.010^{* *} \\
(0.004)\end{array}$ \\
\hline $\begin{array}{l}\text { Age } \geq 60 \times \text { broader } \\
\text { definition of disability }\end{array}$ & $\begin{array}{c}0.008 \\
(0.005)\end{array}$ & $\ldots$ & $\ldots$ & $\begin{array}{l}0.010^{*} \\
(0.006)\end{array}$ & $\begin{array}{l}0.009^{* *} \\
(0.004)\end{array}$ & $\ldots$ & $\cdots$ & $\begin{array}{l}0.013^{* *} \\
(0.006)\end{array}$ \\
\hline Age $\geq 60 \times$ larger damages & $\ldots$ & $\begin{array}{c}0.003 \\
(0.003)\end{array}$ & $\ldots$ & $\begin{array}{c}0.005 \\
(0.004)\end{array}$ & $\ldots$ & $\begin{array}{c}0.003 \\
(0.004)\end{array}$ & $\ldots$ & $\begin{array}{c}0.006 \\
(0.004)\end{array}$ \\
\hline Age $\geq 60 \times$ firm size $<10$ & $\ldots$ & $\ldots$ & $\begin{array}{c}0.001 \\
(0.005)\end{array}$ & $\begin{array}{l}-0.003 \\
(0.005)\end{array}$ & $\ldots$ & $\ldots$ & $\begin{array}{l}-0.002 \\
(0.004)\end{array}$ & $\begin{array}{l}-0.009^{* *} \\
(0.004)\end{array}$ \\
\hline $\begin{array}{l}\text { Age } \geq 60 \times \text { age disc. larger } \\
\text { damages }\end{array}$ & $\ldots$ & $\ldots$ & $\ldots$ & $\ldots$ & $\begin{array}{l}-0.006 \\
(0.004)\end{array}$ & $\begin{array}{l}-0.005 \\
(0.004)\end{array}$ & $\begin{array}{l}-0.003 \\
(0.004)\end{array}$ & $\begin{array}{l}-0.006 \\
(0.004)\end{array}$ \\
\hline $\begin{array}{l}\text { Age } \geq 60 \times \text { age disc. firm } \\
\text { size }<10\end{array}$ & .. & ... & ... & ... & $\begin{array}{c}0.005 \\
(0.004)\end{array}$ & $\begin{array}{c}0.004 \\
(0.005)\end{array}$ & $\begin{array}{l}0.007^{*} \\
(0.004)\end{array}$ & $\begin{array}{l}0.010^{* *} \\
(0.004)\end{array}$ \\
\hline $\mathrm{N}$ & 265,401 & 265,401 & 265,401 & 265,401 & 265,401 & 265,401 & 265,401 & 265,401 \\
\hline
\end{tabular}

Notes: See notes to Table 5 . The only difference is that we exclude the age range $40-49$. 
Appendix Table A5: Estimation Results and Significance Tests for Disability Discrimination Law Provisions, All Hiring, Substituting Fair or Bad Health as a Disability Measure

\begin{tabular}{|c|c|c|c|c|c|c|c|c|c|c|c|c|c|}
\hline & & \multicolumn{4}{|c|}{ Broader definition of disability } & \multicolumn{4}{|c|}{ Larger damages } & \multicolumn{4}{|c|}{ Firm-size minimum $<10$} \\
\hline & & \multicolumn{2}{|c|}{$\underline{\mathrm{HRS}}$} & \multicolumn{2}{|c|}{$\underline{\text { SIPP }}$} & \multicolumn{2}{|c|}{$\underline{\mathrm{HRS}}$} & \multicolumn{2}{|c|}{$\underline{\text { SIPP }}$} & \multicolumn{2}{|c|}{$\underline{\mathrm{HRS}}$} & \multicolumn{2}{|c|}{$\underline{\text { SIPP }}$} \\
\hline & & $\begin{array}{c}\text { Non- } \\
\text { disabled } \\
\text { (1) }\end{array}$ & $\begin{array}{c}\text { Disabled } \\
\text { (2) }\end{array}$ & $\begin{array}{c}\text { Non- } \\
\text { disabled } \\
\text { (3) }\end{array}$ & $\begin{array}{c}\text { Disabled } \\
\text { (4) }\end{array}$ & $\begin{array}{c}\text { Non- } \\
\text { disabled } \\
\text { (5) }\end{array}$ & $\begin{array}{c}\text { Disabled } \\
(6)\end{array}$ & $\begin{array}{c}\text { Non- } \\
\text { disabled } \\
(7)\end{array}$ & $\begin{array}{c}\text { Disabled } \\
\text { (8) }\end{array}$ & $\begin{array}{c}\text { Non- } \\
\text { disabled } \\
(9)\end{array}$ & $\begin{array}{l}\text { Disabled } \\
\text { (10) }\end{array}$ & $\begin{array}{c}\text { Non- } \\
\text { disabled } \\
(11)\end{array}$ & $\begin{array}{c}\text { Disabled } \\
\text { (12) }\end{array}$ \\
\hline Age $20-29$ & $\begin{array}{l}\text { Avg. diff. } \\
\text { \% pos. } \\
\text { p-value }\end{array}$ & $\ldots$ & $\ldots$ & $\begin{array}{c}-0.006 \\
10 \% \\
0.000\end{array}$ & $\begin{array}{c}-0.001 \\
40 \% \\
0.000\end{array}$ & $\ldots$ & $\ldots$ & $\begin{array}{c}-0.0003 \\
40 \% \\
0.430\end{array}$ & $\begin{array}{c}0.006 \\
60 \% \\
0.002\end{array}$ & $\ldots$ & $\ldots$ & $\begin{array}{l}0.001 \\
706 \% \\
0.020\end{array}$ & $\begin{array}{l}0.007 \\
80 \% \\
0.098\end{array}$ \\
\hline Age 30-39 & $\begin{array}{l}\text { Avg. diff. } \\
\text { \% pos. } \\
\text { p-value }\end{array}$ & $\ldots$ & $\ldots$ & $\begin{array}{l}-0.002 \\
20 \% \\
0.000\end{array}$ & $\begin{array}{c}-0.003 \\
40 \% \\
0.000\end{array}$ & $\ldots$ & $\ldots$ & $\begin{array}{c}0.001 \\
80 \% \\
0.007\end{array}$ & $\begin{array}{c}0.001 \\
70 \% \\
0.171\end{array}$ & $\ldots$ & $\cdots$ & $\begin{array}{c}-0.000 \\
40 \% \\
0.007\end{array}$ & $\begin{array}{c}-0.0005 \\
50 \% \\
0.000\end{array}$ \\
\hline Age 40-49 & $\begin{array}{c}\text { Avg. diff. } \\
\text { \% pos. } \\
\text { p-value }\end{array}$ & $\ldots$ & $\ldots$ & $\begin{array}{c}-0.003 \\
0 \% \\
0.000\end{array}$ & $\begin{array}{c}0.001 \\
30 \% \\
0.000\end{array}$ & $\ldots$ & $\ldots$ & $\begin{array}{c}0.001 \\
80 \% \\
0.235\end{array}$ & $\begin{array}{c}0.001 \\
70 \% \\
0.006\end{array}$ & $\ldots$ & $\ldots$ & $\begin{array}{c}-0.002 \\
0 \% \\
0.375\end{array}$ & $\begin{array}{c}-0.001 \\
30 \% \\
0.459\end{array}$ \\
\hline Age 50-61 & $\begin{array}{l}\text { Avg. diff. } \\
\text { \% pos. } \\
\text { p-value }\end{array}$ & $\cdots$ & $\ldots$ & $\begin{array}{c}0.0004 \\
50 \% \\
0.001\end{array}$ & $\begin{array}{c}-0.0002 \\
41.7 \% \\
0.000\end{array}$ & $\cdots$ & $\cdots$ & $\begin{array}{c}0.001 \\
66.7 \% \\
0.001\end{array}$ & $\begin{array}{c}0.0004 \\
66.7 \% \\
0.183\end{array}$ & ... & $\ldots$ & $\begin{array}{c}0.001 \\
66.7 \% \\
0.048\end{array}$ & $\begin{array}{c}0.001 \\
58.3 \% \\
0.000\end{array}$ \\
\hline Age 62-69 & $\begin{array}{l}\text { Avg. diff. } \\
\text { \% pos. } \\
\text { p-value }\end{array}$ & $\begin{array}{c}-0.063 \\
33.3 \% \\
0.954\end{array}$ & $\begin{array}{c}-0.147 \\
37.5 \% \\
0.411\end{array}$ & $\begin{array}{c}-0.0003 \\
50 \% \\
0.000\end{array}$ & $\begin{array}{c}-0.001 \\
37.5 \% \\
0.000\end{array}$ & $\begin{array}{c}-0.113 \\
75 \% \\
0.003\end{array}$ & $\begin{array}{l}-0.148 \\
25 \% \\
0.450\end{array}$ & $\begin{array}{c}-0.0003 \\
37.5 \% \\
0.000\end{array}$ & $\begin{array}{c}0.0002 \\
62.5 \% \\
0.000\end{array}$ & $\begin{array}{c}-0.062 \\
37.5 \% \\
0.272\end{array}$ & $\begin{array}{c}-0.132 \\
25 \% \\
0.074\end{array}$ & $\begin{array}{c}-0.0004 \\
62.5 \% \\
0.026\end{array}$ & $\begin{array}{c}0.001 \\
75 \% \\
0.008\end{array}$ \\
\hline Age $40-52$ & $\begin{array}{l}\text { Avg. diff. } \\
\text { \% pos. } \\
\text { p-value }\end{array}$ & $\ldots$ & $\ldots$ & $\begin{array}{c}-0.002 \\
23.1 \% \\
0.000\end{array}$ & $\begin{array}{c}0.001 \\
38.5 \% \\
0.000\end{array}$ & $\ldots$ & $\ldots$ & $\begin{array}{c}0.001 \\
76.9 \% \\
0.157\end{array}$ & $\begin{array}{c}0.002 \\
76.9 \% \\
0.001\end{array}$ & $\ldots$ & $\ldots$ & $\begin{array}{c}-0.001 \\
15.4 \% \\
0.000\end{array}$ & $\begin{array}{c}0.000 \\
46.2 \% \\
0.003\end{array}$ \\
\hline Age 53-61 & $\begin{array}{l}\text { Avg. diff. } \\
\text { \% pos. } \\
\text { p-value }\end{array}$ & $\begin{array}{c}-0.015 \\
62.5 \% \\
0.710\end{array}$ & $\begin{array}{c}-0.545 \\
0 \% \\
0.002\end{array}$ & $\begin{array}{c}0.000 \\
33.3 \% \\
0.0003\end{array}$ & $\begin{array}{c}-0.001 \\
33.3 \% \\
0.000\end{array}$ & $\begin{array}{c}0.013 \\
22.2 \% \\
0.346\end{array}$ & $\begin{array}{c}-0.075 \\
33.3 \% \\
0.607\end{array}$ & $\begin{array}{c}0.001 \\
66.7 \% \\
0.000\end{array}$ & $\begin{array}{c}-0.0002 \\
55.6 \% \\
0.210\end{array}$ & $\begin{array}{c}-0.048 \\
33.3 \% \\
0.195\end{array}$ & $\begin{array}{c}-0.076 \\
0 \% \\
0.992\end{array}$ & $\begin{array}{c}0.001 \\
66.7 \% \\
0.663\end{array}$ & $\begin{array}{c}0.0002 \\
44.4 \% \\
0.002\end{array}$ \\
\hline Age 53-69 & $\begin{array}{c}\text { Avg. diff. } \\
\text { \% pos. } \\
\text { p-value }\end{array}$ & $\begin{array}{c}-0.037 \\
47.1 \% \\
0.942\end{array}$ & $\begin{array}{c}-0.371 \\
18.8 \% \\
0.007\end{array}$ & $\begin{array}{c}-0.0002 \\
41.2 \% \\
0.000\end{array}$ & $\begin{array}{c}-0.001 \\
35.3 \% \\
0.000\end{array}$ & $\begin{array}{l}-0.047 \\
47.1 \% \\
0.010\end{array}$ & $\begin{array}{c}-0.109 \\
23.5 \% \\
0.590\end{array}$ & $\begin{array}{c}0.0003 \\
52.9 \% \\
0.000\end{array}$ & $\begin{array}{c}0.000 \\
58.8 \% \\
0.000\end{array}$ & $\begin{array}{c}-0.055 \\
35.3 \% \\
0.183\end{array}$ & $\begin{array}{c}-0.102 \\
11.8 \% \\
0.507\end{array}$ & $\begin{array}{c}0.0003 \\
64.7 \% \\
0.001\end{array}$ & $\begin{array}{c}0.001 \\
58.8 \% \\
0.000\end{array}$ \\
\hline
\end{tabular}

Notes: Notes from Appendix Table A2 apply, with the exception that the definition of disability used is based on self-reported health being fair or bad (other options are good, very good, or excellent). 
Appendix Table A6: Difference-in-Differences Estimates of Effects of Stronger Disability Discrimination Laws on Hiring of Non-Disabled Older Workers, SIPP Data, All Hiring, Substituting Fair or Bad Health as a Disability Measure

\begin{tabular}{|c|c|c|c|c|c|c|c|c|}
\hline & (1) & (2) & (3) & (4) & (5) & (6) & (7) & (8) \\
\hline $\begin{array}{l}\text { Age } \geq 50 \times \text { broader } \\
\text { definition of disability }\end{array}$ & $\begin{array}{l}0.003^{* *} \\
(0.001)\end{array}$ & ... & $\ldots$ & $\begin{array}{l}0.002^{* *} \\
(0.001)\end{array}$ & $\begin{array}{l}0.003^{* * *} \\
(0.001)\end{array}$ & $\ldots$ & $\ldots$ & $\begin{array}{l}0.002^{* *} \\
(0.001)\end{array}$ \\
\hline $\begin{array}{l}\text { Age } \geq 50 \times \text { larger } \\
\text { damages }\end{array}$ & ... & $\begin{array}{l}-0.0004 \\
(0.001)\end{array}$ & $\ldots$ & $\begin{array}{l}-0.0004 \\
(0.001)\end{array}$ & $\ldots$ & $\begin{array}{l}-0.001 \\
(0.001)\end{array}$ & $\ldots$ & $\begin{array}{l}-0.001 \\
(0.001)\end{array}$ \\
\hline Age $\geq 50 \times$ firm size $<10$ & $\ldots$ & $\ldots$ & $\begin{array}{l}0.001^{* *} \\
(0.001)\end{array}$ & $\begin{array}{c}0.001 \\
(0.001)\end{array}$ & $\ldots$ & $\ldots$ & $\begin{array}{l}0.002^{* * *} \\
(0.001)\end{array}$ & $\begin{array}{c}0.001 \\
(0.001)\end{array}$ \\
\hline $\begin{array}{l}\text { Age } \geq 50 \times \text { age disc } \\
\text { larger damages }\end{array}$ & $\ldots$ & $\ldots$ & $\ldots$ & $\ldots$ & $\begin{array}{l}0.0005 \\
(0.001)\end{array}$ & $\begin{array}{c}0.001 \\
(0.001)\end{array}$ & $\begin{array}{c}0.001 \\
(0.001)\end{array}$ & $\begin{array}{l}0.0005 \\
(0.001)\end{array}$ \\
\hline $\begin{array}{l}\text { Age } \geq 50 \times \text { age disc. firm } \\
\text { size }<10\end{array}$ & $\ldots$ & $\cdots$ & $\ldots$ & $\cdots$ & $\begin{array}{c}0.0003 \\
(0.0004)\end{array}$ & $\begin{array}{c}0.001 \\
(0.001)\end{array}$ & $\begin{array}{l}-0.001 \\
(0.001)\end{array}$ & $\begin{array}{r}-0.0001 \\
(0.001)\end{array}$ \\
\hline $\begin{array}{l}\text { Age } \geq 55 \times \text { broader } \\
\text { definition of disability }\end{array}$ & $\begin{array}{l}0.002^{* *} \\
(0.001)\end{array}$ & $\ldots$ & $\ldots$ & $\begin{array}{c}0.002^{*} \\
(0.001)\end{array}$ & $\begin{array}{l}0.002^{* *} \\
(0.001)\end{array}$ & $\ldots$ & $\ldots$ & $\begin{array}{c}0.002 \\
(0.001)\end{array}$ \\
\hline $\begin{array}{l}\text { Age } \geq 55 \times \text { larger } \\
\text { damages }\end{array}$ & $\ldots$ & $\begin{array}{l}-0.0002 \\
(0.001)\end{array}$ & $\ldots$ & $\begin{array}{r}-0.0003 \\
(0.001)\end{array}$ & $\ldots$ & $\begin{array}{l}-0.001 \\
(0.001)\end{array}$ & $\ldots$ & $\begin{array}{l}-0.0003 \\
(0.001)\end{array}$ \\
\hline Age $\geq 55 \times$ firm size $<10$ & $\ldots$ & $\ldots$ & $\begin{array}{c}0.001 \\
(0.001)\end{array}$ & $\begin{array}{c}0.001 \\
(0.001)\end{array}$ & $\ldots$ & $\ldots$ & $\begin{array}{c}0.002 \\
(0.001)\end{array}$ & $\begin{array}{c}0.001 \\
(0.001)\end{array}$ \\
\hline $\begin{array}{l}\text { Age } \geq 55 \times \text { age disc. } \\
\text { larger damages }\end{array}$ & $\ldots$ & $\ldots$ & $\ldots$ & $\ldots$ & $\begin{array}{l}0.0001 \\
(0.001)\end{array}$ & $\begin{array}{l}0.0001 \\
(0.001)\end{array}$ & $\begin{array}{l}0.0001 \\
(0.001)\end{array}$ & $\begin{array}{c}0.000 \\
(0.001)\end{array}$ \\
\hline $\begin{array}{l}\text { Age } \geq 55 \times \text { age disc. firm } \\
\text { size }<10\end{array}$ & $\ldots$ & $\ldots$ & $\ldots$ & $\ldots$ & $\begin{array}{l}0.0003 \\
(0.001)\end{array}$ & $\begin{array}{l}0.0004 \\
(0.001)\end{array}$ & $\begin{array}{l}-0.001 \\
(0.001)\end{array}$ & $\begin{array}{r}-0.0002 \\
(0.001)\end{array}$ \\
\hline $\begin{array}{l}\text { Age } \geq 60 \times \text { broader } \\
\text { definition of disability }\end{array}$ & $\begin{array}{l}0.001^{*} \\
(0.001)\end{array}$ & $\ldots$ & $\ldots$ & $\begin{array}{l}0.001^{*} \\
(0.001)\end{array}$ & $\begin{array}{l}0.001^{*} \\
(0.001)\end{array}$ & $\ldots$ & $\ldots$ & $\begin{array}{c}0.001 \\
(0.001)\end{array}$ \\
\hline $\begin{array}{l}\text { Age } \geq 60 \times \text { larger } \\
\text { damages }\end{array}$ & $\ldots$ & $\begin{array}{l}-0.001 \\
(0.001)\end{array}$ & $\ldots$ & $\begin{array}{l}-0.001 \\
(0.001)\end{array}$ & $\ldots$ & $\begin{array}{l}-0.001 \\
(0.001)\end{array}$ & $\ldots$ & $\begin{array}{l}-0.001 \\
(0.001)\end{array}$ \\
\hline Age $\geq 60 \times$ firm size $<10$ & $\ldots$ & $\ldots$ & $\begin{array}{l}0.0002 \\
(0.001)\end{array}$ & $\begin{array}{l}0.0002 \\
(0.001)\end{array}$ & $\ldots$ & $\ldots$ & $\begin{array}{c}0.001 \\
(0.001)\end{array}$ & $\begin{array}{l}0.0002 \\
(0.001)\end{array}$ \\
\hline $\begin{array}{l}\text { Age } \geq 60 \times \text { age disc. } \\
\text { larger damages }\end{array}$ & $\ldots$ & $\ldots$ & $\ldots$ & $\ldots$ & $\begin{array}{l}-0.001 \\
(0.001)\end{array}$ & $\begin{array}{l}-0.0001 \\
(0.001)\end{array}$ & $\begin{array}{l}-0.0004 \\
(0.001)\end{array}$ & $\begin{array}{l}-0.0004 \\
(0.001)\end{array}$ \\
\hline $\begin{array}{l}\text { Age } \geq 60 \times \text { age disc. firm } \\
\text { size }<10\end{array}$ & $\ldots$ & $\ldots$ & $\ldots$ & $\ldots$ & $\begin{array}{c}0.000 \\
(0.001)\end{array}$ & $\begin{array}{l}0.0003 \\
(0.001)\end{array}$ & $\begin{array}{l}-0.0003 \\
(0.001)\end{array}$ & $\begin{array}{l}0.0001 \\
(0.001)\end{array}$ \\
\hline $\mathrm{N}$ & $2,344,711$ & $2,344,711$ & $2,344,711$ & $2,344,711$ & $2,344,711$ & $2,344,711$ & $2,344,711$ & $2,344,711$ \\
\hline
\end{tabular}

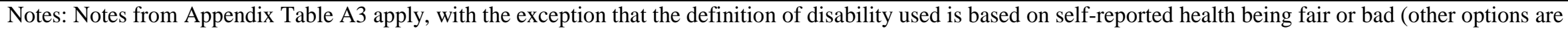
good, very good, or excellent). 
Appendix Table A7: Difference-in-Differences Estimates of Effects of Stronger Disability Discrimination Laws on Hiring of Non-Disabled Older Workers, SIPP Data, Excluding Age 40-49 from the Control Group, Hiring from Non-Employment, Substituting Fair or Bad Health as a Disability Measure

\begin{tabular}{|c|c|c|c|c|c|c|c|c|}
\hline & (1) & (2) & (3) & (4) & (5) & (6) & (7) & (8) \\
\hline $\begin{array}{l}\text { Age } \geq 50 \times \text { broader } \\
\text { definition of disability }\end{array}$ & $\begin{array}{c}0.005 \\
(0.008)\end{array}$ & $\cdots$ & ... & $\begin{array}{c}0.004 \\
(0.010)\end{array}$ & $\begin{array}{c}0.005 \\
(0.008)\end{array}$ & $\cdots$ & $\ldots$ & $\begin{array}{c}0.005 \\
(0.011)\end{array}$ \\
\hline $\begin{array}{l}\text { Age } \geq 50 \times \text { larger } \\
\text { damages }\end{array}$ & $\ldots$ & $\begin{array}{c}0.003 \\
(0.005)\end{array}$ & $\ldots$ & $\begin{array}{c}0.002 \\
(0.006)\end{array}$ & $\ldots$ & $\begin{array}{c}0.002 \\
(0.006)\end{array}$ & $\ldots$ & $\begin{array}{c}0.003 \\
(0.007)\end{array}$ \\
\hline Age $\geq 50 \times$ firm size $<10$ & $\ldots$ & $\ldots$ & $\begin{array}{c}0.005 \\
(0.005)\end{array}$ & $\begin{array}{c}0.003 \\
(0.006)\end{array}$ & $\ldots$ & $\ldots$ & $\begin{array}{c}0.006 \\
(0.006)\end{array}$ & $\begin{array}{c}0.003 \\
(0.008)\end{array}$ \\
\hline $\begin{array}{l}\text { Age } \geq 50 \times \text { age disc } \\
\text { larger damages }\end{array}$ & $\ldots$ & $\ldots$ & $\ldots$ & $\ldots$ & $\begin{array}{l}-0.003 \\
(0.005)\end{array}$ & $\begin{array}{l}-0.003 \\
(0.005)\end{array}$ & $\begin{array}{l}-0.004 \\
(0.006)\end{array}$ & $\begin{array}{l}-0.005 \\
(0.006)\end{array}$ \\
\hline $\begin{array}{l}\text { Age } \geq 50 \times \text { age disc. firm } \\
\text { size }<10\end{array}$ & $\cdots$ & $\ldots$ & $\cdots$ & $\cdots$ & $\begin{array}{c}0.004 \\
(0.005) \\
\end{array}$ & $\begin{array}{c}0.004 \\
(0.005) \\
\end{array}$ & $\begin{array}{l}0.0004 \\
(0.004)\end{array}$ & $\begin{array}{c}0.001 \\
(0.006)\end{array}$ \\
\hline $\begin{array}{l}\text { Age } \geq 55 \times \text { broader } \\
\text { definition of disability }\end{array}$ & $\begin{array}{c}0.004 \\
(0.008)\end{array}$ & $\ldots$ & $\ldots$ & $\begin{array}{c}0.001 \\
(0.009)\end{array}$ & $\begin{array}{c}0.005 \\
(0.007)\end{array}$ & $\ldots$ & $\ldots$ & $\begin{array}{c}0.004 \\
(0.010)\end{array}$ \\
\hline $\begin{array}{l}\text { Age } \geq 55 \times \text { larger } \\
\text { damages }\end{array}$ & $\ldots$ & $\begin{array}{c}0.003 \\
(0.005)\end{array}$ & $\ldots$ & $\begin{array}{c}0.001 \\
(0.006)\end{array}$ & $\ldots$ & $\begin{array}{c}0.002 \\
(0.006)\end{array}$ & $\ldots$ & $\begin{array}{c}0.003 \\
(0.006)\end{array}$ \\
\hline Age $\geq 55 \times$ firm size $<10$ & $\ldots$ & $\ldots$ & $\begin{array}{c}0.007 \\
(0.005)\end{array}$ & $\begin{array}{c}0.006 \\
(0.006)\end{array}$ & $\ldots$ & $\ldots$ & $\begin{array}{c}0.007 \\
(0.005)\end{array}$ & $\begin{array}{c}0.005 \\
(0.006)\end{array}$ \\
\hline $\begin{array}{l}\text { Age } \geq 55 \times \text { age disc } \\
\text { larger damages }\end{array}$ & $\ldots$ & $\ldots$ & $\ldots$ & $\ldots$ & $\begin{array}{l}-0.005 \\
(0.005)\end{array}$ & $\begin{array}{l}-0.005 \\
(0.005)\end{array}$ & $\begin{array}{l}-0.006 \\
(0.005)\end{array}$ & $\begin{array}{l}-0.007 \\
(0.005)\end{array}$ \\
\hline $\begin{array}{l}\text { Age } \geq 55 \times \text { age disc. firm } \\
\text { size }<10\end{array}$ & $\ldots$ & $\ldots$ & $\ldots$ & $\ldots$ & $\begin{array}{c}0.007 \\
(0.005)\end{array}$ & $\begin{array}{c}0.006 \\
(0.006)\end{array}$ & $\begin{array}{c}0.002 \\
(0.004)\end{array}$ & $\begin{array}{c}0.002 \\
(0.005)\end{array}$ \\
\hline $\begin{array}{l}\text { Age } \geq 60 \times \text { broader } \\
\text { definition of disability }\end{array}$ & $\begin{array}{c}0.001 \\
(0.006)\end{array}$ & $\ldots$ & $\ldots$ & $\begin{array}{c}0.001 \\
(0.006)\end{array}$ & $\begin{array}{c}0.003 \\
(0.005)\end{array}$ & $\ldots$ & $\ldots$ & $\begin{array}{c}0.004 \\
(0.007)\end{array}$ \\
\hline $\begin{array}{l}\text { Age } \geq 60 \times \text { larger } \\
\text { damages }\end{array}$ & $\ldots$ & $\begin{array}{c}0.002 \\
(0.003)\end{array}$ & $\ldots$ & $\begin{array}{c}0.001 \\
(0.004)\end{array}$ & $\ldots$ & $\begin{array}{c}0.002 \\
(0.004)\end{array}$ & $\ldots$ & $\begin{array}{c}0.003 \\
(0.004)\end{array}$ \\
\hline Age $\geq 60 \times$ firm size $<10$ & $\ldots$ & $\ldots$ & $\begin{array}{c}0.002 \\
(0.004)\end{array}$ & $\begin{array}{l}0.0012 \\
(0.005)\end{array}$ & $\ldots$ & $\ldots$ & $\begin{array}{c}0.001 \\
(0.003)\end{array}$ & $\begin{array}{l}-0.001 \\
(0.004)\end{array}$ \\
\hline $\begin{array}{l}\text { Age } \geq 60 \times \text { age disc } \\
\text { larger damages }\end{array}$ & $\ldots$ & $\ldots$ & $\cdots$ & $\ldots$ & $\begin{array}{l}-0.006 \\
(0.003)\end{array}$ & $\begin{array}{l}-0.006 \\
(0.004)\end{array}$ & $\begin{array}{l}-0.006 \\
(0.003)\end{array}$ & $\begin{array}{l}-0.006^{*} \\
(0.004)\end{array}$ \\
\hline $\begin{array}{l}\text { Age } \geq 60 \times \text { age disc. firm } \\
\text { size }<10\end{array}$ & $\ldots$ & $\ldots$ & $\ldots$ & $\ldots$ & $\begin{array}{c}0.005 \\
(0.004)\end{array}$ & $\begin{array}{c}0.004 \\
(0.004)\end{array}$ & $\begin{array}{c}0.004 \\
(0.003)\end{array}$ & $\begin{array}{c}0.005 \\
(0.004)\end{array}$ \\
\hline $\mathrm{N}$ & 268,868 & 268,868 & 268,868 & 268,868 & 268,868 & 268,868 & 268,868 & 268,868 \\
\hline
\end{tabular}

Notes: Notes from Appendix Table A4 apply, with the exception that the definition of disability used is based on self-reported health being fair or bad (other options are good, very good, or excellent). 
Appendix Table A8: Difference-in-Differences Estimates of Effects of Stronger Disability Discrimination Laws on Hiring of Non-Disabled Older Workers, SIPP Data, Hiring from Non-Employment, Substituting Having Work-limiting Disability This and Last Wave

\begin{tabular}{|c|c|c|c|c|c|c|c|c|}
\hline & (1) & (2) & (3) & (4) & (5) & (6) & (7) & (8) \\
\hline $\begin{array}{l}\text { Age } \geq 50 \times \text { broader } \\
\text { definition of disability }\end{array}$ & $\begin{array}{c}0.010 \\
(0.009)\end{array}$ & $\ldots$ & $\ldots$ & $\begin{array}{c}0.015 \\
(0.011)\end{array}$ & $\begin{array}{c}0.009 \\
(0.008)\end{array}$ & $\ldots$ & $\ldots$ & $\begin{array}{c}0.017 \\
(0.012)\end{array}$ \\
\hline $\begin{array}{l}\text { Age } \geq 50 \times \text { larger } \\
\text { damages }\end{array}$ & $\ldots$ & $\begin{array}{c}0.009^{*} \\
(0.005)\end{array}$ & $\ldots$ & $\begin{array}{c}0.012^{*} \\
(0.006)\end{array}$ & $\ldots$ & $\begin{array}{c}0.008 \\
(0.007)\end{array}$ & $\ldots$ & $\begin{array}{c}0.012 \\
(0.007)\end{array}$ \\
\hline Age $\geq 50 \times$ firm size $<10$ & $\ldots$ & $\ldots$ & $\begin{array}{c}0.001 \\
(0.006)\end{array}$ & $\begin{array}{l}-0.007 \\
(0.006)\end{array}$ & $\ldots$ & $\ldots$ & $\begin{array}{l}-0.006 \\
(0.006)\end{array}$ & $\begin{array}{l}-0.015 \\
(0.008)\end{array}$ \\
\hline $\begin{array}{l}\text { Age } \geq 50 \times \text { age disc } \\
\text { larger damages }\end{array}$ & $\ldots$ & $\ldots$ & $\ldots$ & $\ldots$ & $\begin{array}{c}0.003 \\
(0.006)\end{array}$ & $\begin{array}{c}0.003 \\
(0.006)\end{array}$ & $\begin{array}{c}0.006 \\
(0.006)\end{array}$ & $\begin{array}{c}0.003 \\
(0.005)\end{array}$ \\
\hline $\begin{array}{l}\text { Age } \geq 50 \times \text { age disc. firm } \\
\text { size }<10\end{array}$ & $\ldots$ & $\ldots$ & $\ldots$ & $\ldots$ & $\begin{array}{c}0.002 \\
(0.006)\end{array}$ & $\begin{array}{c}0.001 \\
(0.006)\end{array}$ & $\begin{array}{c}0.007 \\
(0.006)\end{array}$ & $\begin{array}{c}0.010 \\
(0.007)\end{array}$ \\
\hline $\begin{array}{l}\text { Age } \geq 55 \times \text { broader } \\
\text { definition of disability }\end{array}$ & $\begin{array}{c}0.008 \\
(0.009)\end{array}$ & $\cdots$ & $\cdots$ & $\begin{array}{c}0.011 \\
(0.011)\end{array}$ & $\begin{array}{c}0.008 \\
(0.008)\end{array}$ & $\ldots$ & $\ldots$ & $\begin{array}{c}0.013 \\
(0.011)\end{array}$ \\
\hline $\begin{array}{l}\text { Age } \geq 55 \times \text { larger } \\
\text { damages }\end{array}$ & $\ldots$ & $\begin{array}{c}0.007 \\
(0.005)\end{array}$ & $\ldots$ & $\begin{array}{c}0.009 \\
(0.006)\end{array}$ & $\ldots$ & $\begin{array}{c}0.006 \\
(0.007)\end{array}$ & $\ldots$ & $\begin{array}{l}0.008 \\
(0.007)\end{array}$ \\
\hline Age $\geq 55 \times$ firm size $<10$ & $\ldots$ & $\ldots$ & $\begin{array}{c}0.003 \\
(0.005)\end{array}$ & $\begin{array}{l}-0.003 \\
(0.006)\end{array}$ & $\ldots$ & $\ldots$ & $\begin{array}{l}-0.003 \\
(0.005)\end{array}$ & $\begin{array}{l}-0.009 \\
(0.007)\end{array}$ \\
\hline $\begin{array}{l}\text { Age } \geq 55 \times \text { age disc } \\
\text { larger damages }\end{array}$ & $\ldots$ & $\ldots$ & $\ldots$ & $\ldots$ & $\begin{array}{c}0.001 \\
(0.005)\end{array}$ & $\begin{array}{c}0.001 \\
(0.006)\end{array}$ & $\begin{array}{c}0.003 \\
(0.005)\end{array}$ & $\begin{array}{l}0.0004 \\
(0.005)\end{array}$ \\
\hline $\begin{array}{l}\text { Age } \geq 55 \times \text { age disc. firm } \\
\text { size }<10\end{array}$ & $\ldots$ & $\ldots$ & $\ldots$ & $\ldots$ & $\begin{array}{c}0.004 \\
(0.005) \\
\end{array}$ & $\begin{array}{c}0.003 \\
(0.006) \\
\end{array}$ & $\begin{array}{c}0.006 \\
(0.005) \\
\end{array}$ & $\begin{array}{c}0.009 \\
(0.006) \\
\end{array}$ \\
\hline $\begin{array}{l}\text { Age } \geq 60 \times \text { broader } \\
\text { definition of disability }\end{array}$ & $\begin{array}{c}0.003 \\
(0.007)\end{array}$ & $\ldots$ & $\cdots$ & $\begin{array}{c}0.006 \\
(0.008)\end{array}$ & $\begin{array}{c}0.003 \\
(0.006)\end{array}$ & ‥ & $\ldots$ & $\begin{array}{l}0.008 \\
(0.008)\end{array}$ \\
\hline $\begin{array}{l}\text { Age } \geq 60 \times \text { larger } \\
\text { damages }\end{array}$ & $\ldots$ & $\begin{array}{c}0.005 \\
(0.004)\end{array}$ & $\ldots$ & $\begin{array}{c}0.007 \\
(0.004)\end{array}$ & $\ldots$ & $\begin{array}{c}0.005 \\
(0.005)\end{array}$ & $\ldots$ & $\begin{array}{l}0.007 \\
(0.005)\end{array}$ \\
\hline Age $\geq 60 \times$ firm size $<10$ & $\ldots$ & $\ldots$ & $\begin{array}{l}-0.001 \\
(0.004)\end{array}$ & $\begin{array}{l}-0.004 \\
(0.004)\end{array}$ & $\ldots$ & $\ldots$ & $\begin{array}{l}-0.006^{*} \\
(0.003)\end{array}$ & $\begin{array}{l}-0.011^{* *} \\
(0.005)\end{array}$ \\
\hline $\begin{array}{l}\text { Age } \geq 60 \times \text { age disc } \\
\text { larger damages }\end{array}$ & $\ldots$ & $\ldots$ & $\ldots$ & $\ldots$ & $\begin{array}{l}-0.001 \\
(0.004)\end{array}$ & $\begin{array}{l}-0.001 \\
(0.004)\end{array}$ & $\begin{array}{c}0.001 \\
(0.004)\end{array}$ & $\begin{array}{l}-0.001 \\
(0.004)\end{array}$ \\
\hline $\begin{array}{l}\text { Age } \geq 60 \times \text { age disc. firm } \\
\text { size }<10\end{array}$ & $\ldots$ & $\ldots$ & $\ldots$ & $\ldots$ & $\begin{array}{c}0.003 \\
(0.004)\end{array}$ & $\begin{array}{c}0.002 \\
(0.004)\end{array}$ & $\begin{array}{c}0.008 \\
(0.004)\end{array}$ & $\begin{array}{l}0.009^{* *} \\
(0.004)\end{array}$ \\
\hline $\mathrm{N}$ & 191,319 & 191,319 & 191,319 & 191,319 & 191,319 & 191,319 & 191,319 & 191,319 \\
\hline
\end{tabular}

Notes: See notes to Table 5 . The difference is that the definition of disability used is based having work-limiting disability this and last wave. We restrict our sample to respondents who remain in the survey throughout all waves within each panel. 
Appendix Table A1: Relationships between Alternative Disability Measures, Difficulties in Activities, Functional Limitations, and Doctor-Diagnosed Medical Problems

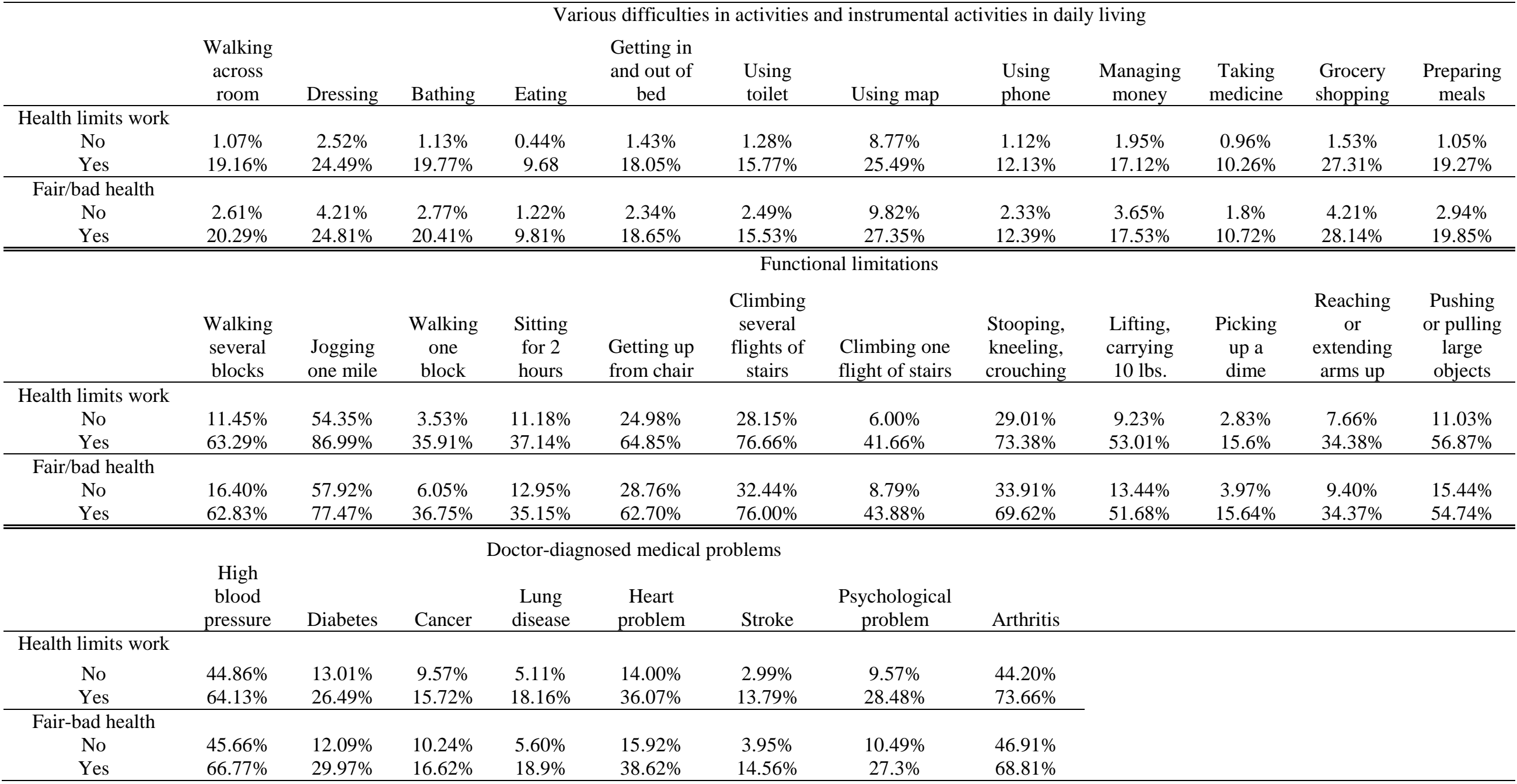

Notes: These calculations are based on HRS raw data, without adjustment. We are reporting conditional distribution of "health limits work" and "fair/bad health" for respondents who report having difficulty doing the specified activities or specified doctor-diagnosed medical problems. 